\title{
Catalog of Earthquake Hypocenters at Alaskan Volcanoes: January 1 through December 31, 2012
}

Data Series 789

U.S. Department of the Interior

U.S. Geological Survey 



\section{Catalog of Earthquake Hypocenters at Alaskan Volcanoes: January 1 through December 31, 2012}

By James P. Dixon, U.S. Geological Survey; Scott D. Stihler, University of Alaska

Fairbanks; and John A. Power, Matt Haney, Tom Parker, Cheryl K. Searcy, and

Stephanie Prejean, U.S. Geological Survey

Data Series 789 


\title{
U.S. Department of the Interior SALLY JEWELL, Secretary
}

\section{U.S. Geological Survey Suzette M. Kimball, Acting Director}

\author{
U.S. Geological Survey, Reston, Virginia: 2013
}

For more information on the USGS - the Federal source for science about the Earth, its natural and living resources, natural hazards, and the environment, visit http://www.usgs.gov or call 1-888-ASK-USGS.

For an overview of USGS information products, including maps, imagery, and publications, visit http://www.usgs.gov/pubprod

To order this and other USGS information products, visit http://store.usgs.gov

Any use of trade, product, or firm names is for descriptive purposes only and does not imply endorsement by the U.S. Government.

Although this report is in the public domain, permission must be secured from the individual copyright owners to reproduce any copyrighted materials contained within this report.

Suggested citation:

Dixon, J.P., Stihler, S.D., Power, J.A., Haney, Matt, Parker, Tom, Searcy, C.K., and Prejean, Stephanie, 2013, Catalog of earthquake hypocenters at Alaskan volcanoes: January 1 through December 31, 2012: U.S. Geological Survey Data Series 789, 84 p., http://pubs.usgs.gov/ds/789/. 


\section{Contents}

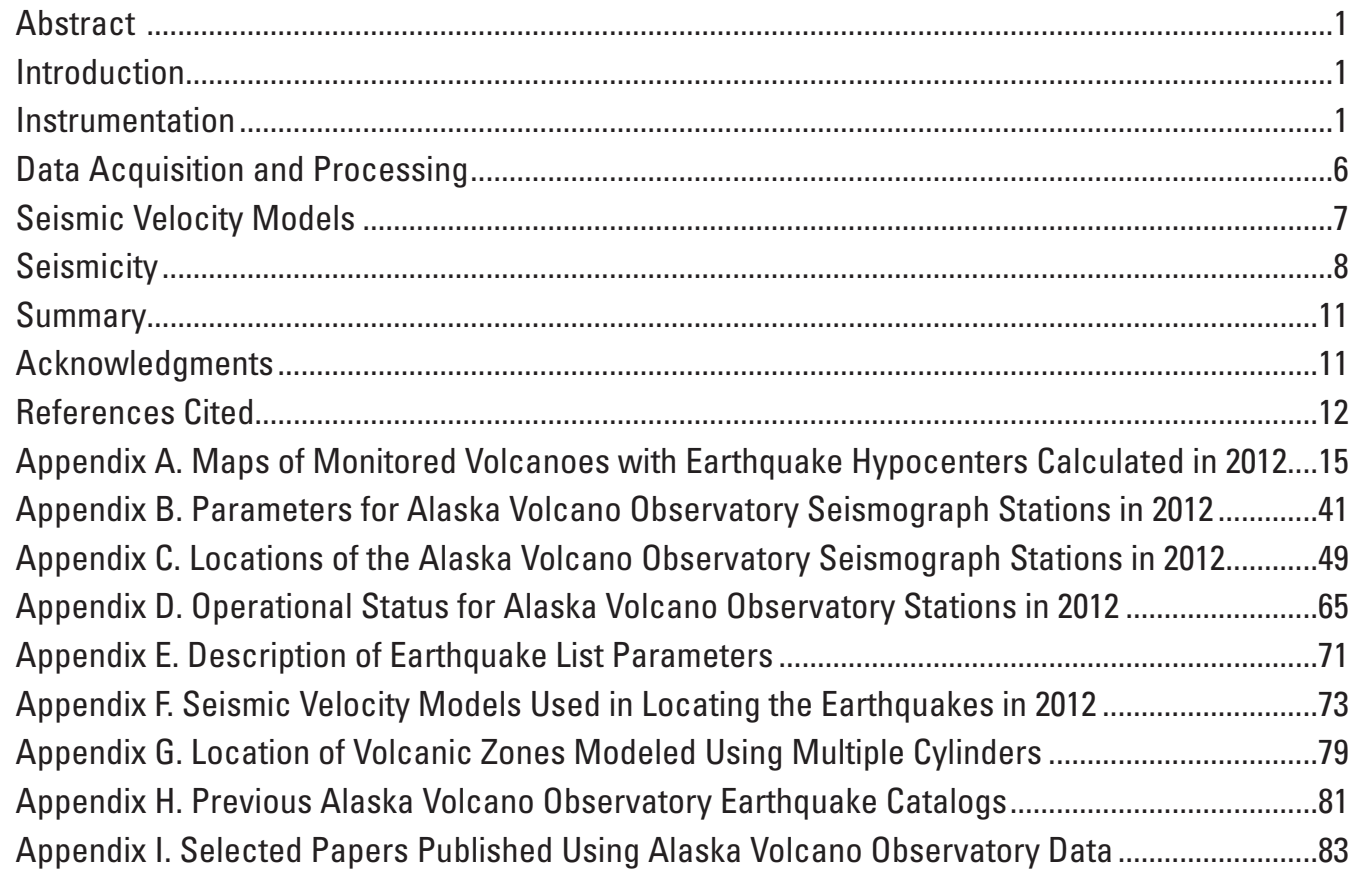

\section{Figures}

1. Map showing location of volcanoes mentioned in this report $\ldots \ldots \ldots \ldots \ldots \ldots \ldots \ldots .2$

2. Graph showing number of AVO seismograph stations by type and year $\ldots \ldots \ldots \ldots 2$

3. Log-log plot of representative displacement response curves for AVO short-period stations using a L4 (black), S13 (red), or L22 (green) seismometer ... 5

4. Log-log plot of representative displacement response curves for the AVO broadband stations using a CMG-6TD (black) or CMG-40T (red) seismometer ..... 5

5. Graph showing number of earthquakes located per year in the AVO catalog and number of volcanoes with a seismic network per year .............. 8

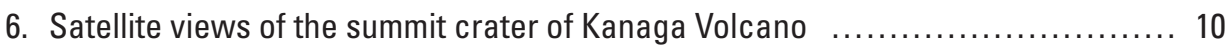

\section{Tables}

1. Number of permanent AVO seismograph stations by type and network in $2012 \quad \ldots \quad 3$

2. Number of AVO seismograph stations by type and year $\ldots \ldots \ldots \ldots \ldots \ldots \ldots \ldots$

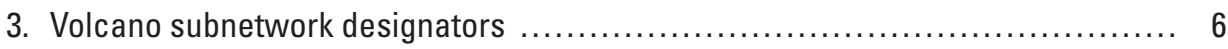

4. Number of earthquakes located for each seismograph subnetwork in 2012 within $20 \mathrm{~km}$ of the volcanic centers in each subnetwork. $\ldots \ldots \ldots \ldots \ldots \ldots \ldots . \ldots$

5. Number of earthquakes located per year in the AVO earthquake catalog $\ldots \ldots \ldots 10$ 


\section{Conversion Factors and Datum}

Conversion Factors

\begin{tabular}{|c|c|c|}
\hline Multiply & By & To obtain \\
\hline $\begin{array}{l}\text { kilometer }(\mathrm{km}) \\
\text { meter }(\mathrm{m})\end{array}$ & $\begin{array}{l}0.6214 \\
3.281\end{array}$ & $\begin{array}{l}\text { mile }(\mathrm{mi}) \\
\text { foot }(\mathrm{ft})\end{array}$ \\
\hline
\end{tabular}

Datum

Horizontal coordinate information is referenced to World Geodetic System of 1984 (WGS84). 


\title{
Catalog of Earthquake Hypocenters at Alaskan Volcanoes: January 1 through December 31, 2012
}

\author{
By James P. Dixon'1, Scott D. Stihler², John A. Power³, Matt Haney', Tom Parker', Cheryl Searcy³, and \\ Stephanie Prejean ${ }^{3}$
}

\section{Abstract}

Between January 1 and December 31, 2012, the Alaska Volcano Observatory located 4,787 earthquakes, of which 4,211 occurred within 20 kilometers of the 33 volcanoes monitored by a seismograph network. There was significant seismic activity at Iliamna, Kanaga, and Little Sitkin volcanoes in 2012. Instrumentation highlights for this year include the implementation of the Advanced National Seismic System Quake Monitoring System hardware and software in February 2012 and the continuation of the American Recovery and Reinvestment Act work in the summer of 2012. The operational highlight was the removal of Mount Wrangell from the list of monitored volcanoes. This catalog includes hypocenters, magnitudes, and statistics of the earthquakes located in 2012 with the station parameters, velocity models, and other files used to locate these earthquakes.

\section{Introduction}

In 1988, the Alaska Volcano Observatory (AVO) was established as a cooperative program of the U.S. Geological Survey, the Geophysical Institute at the University of Alaska Fairbanks, and the Alaska Division of Geological and Geophysical Surveys. The AVO initially monitored four volcanoes in the Cook Inlet region (Mount Spurr, Redoubt Volcano, Iliamna Volcano, and Augustine Volcano) and in the last 25 years, AVO established seismograph networks on 33 of the 52 historically active volcanoes in Alaska (Schaefer and others, 2009) (fig. 1). The primary objectives of the AVO seismic program are the real-time seismic monitoring of active and potentially hazardous Alaskan volcanoes and the investigation of seismic processes associated with active volcanism.

Four out of the 33 historically active volcanic centers with seismograph networks were not on the formal list of permanently monitored volcanoes in the AVO weekly update at the end of 2012. In order to be included on the monitored list in the AVO weekly update, a seismic subnetwork (a local seismograph network designed for the location of earthquakes in the vicinity of a specific volcano) on the volcano must be in place long enough to determine the level of background seismicity (typically 6 months) and have had no prolonged station outages. Loss of data due to telemetry outages since their installation in 2005 has prevented Little Sitkin and Mount Cerberus, the active vent on Semisopochnoi Island, from being added to list of permanently monitored volcanoes. Korovin was delisted in October 2011 and was not reinstated on the formal list of permanently monitored volcanoes at the end of 2012. Prolonged station outages at Mount Wrangell persisted into 2012 and this volcano was removed on January 27, 2012, from the monitored list.

This catalog describes the (1) location of seismic instrumentation deployed in the field; (2) earthquake detection, recording, analysis, and data archival systems; (3) seismic velocity models used for earthquake locations; and (4) summary of earthquakes located in 2012. A summary of earthquake origin times, hypocenters, magnitudes, phase arrival times, location quality statistics, all files used to determine the earthquake locations in 2012, and a metadata file in the format of a dataless Standard for the Exchange of Earthquake Data (SEED) volume (SEED Manual, 2010) for the AVO seismograph network are included in a data supplement to this report.

\section{Instrumentation}

The permanent AVO seismograph network is composed of 24 subnetworks each with 4 to 20 seismograph stations and 10 regional seismograph stations for a total of 202 stations (tables 1 and 2; fig. 2). Three broadband seismograph stations were added to the AVO seismograph networks in 2012, all to the Makushin subnetwork. Two were co-located with shortperiod sensors, MGOD and MNAT. A third broadband station (MAPS) was installed near MSOM, which was then removed.

\footnotetext{
${ }^{1}$ U.S. Geological Survey, Volcano Science Center, 903 Koyukuk Drive, Fairbanks, AK 99775.

${ }^{2}$ University of Alaska Fairbanks, Geophysical Institute, 903 Koyukuk Drive, Fairbanks, AK 99775.

${ }^{3}$ U.S. Geological Survey, Volcano Science Center, 4210 University Drive, Anchorage, AK 99508.
} 


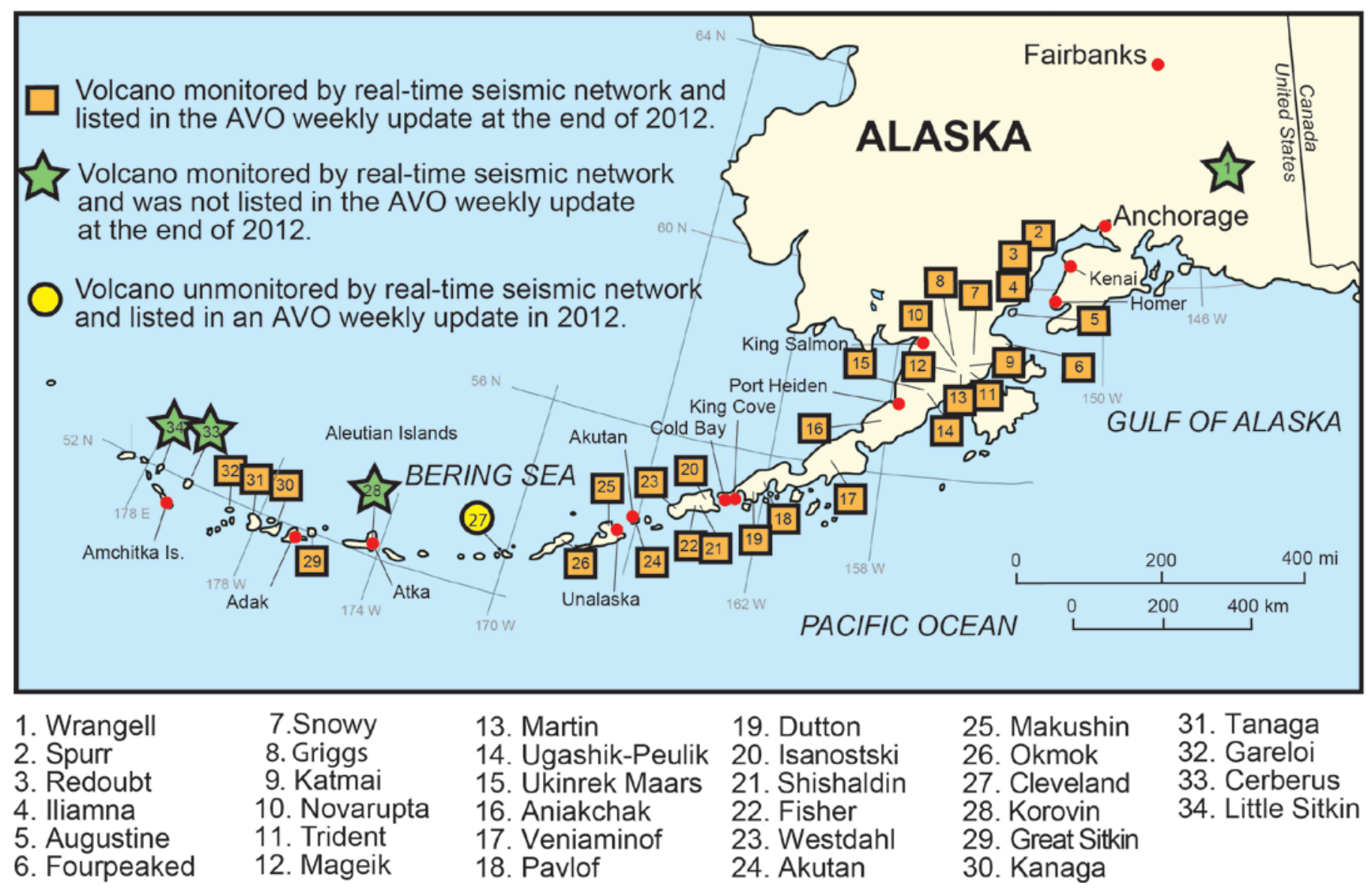

Figure 1. Location of volcanoes mentioned in this report. Red dots show locations of towns and other sites referred to in this report.

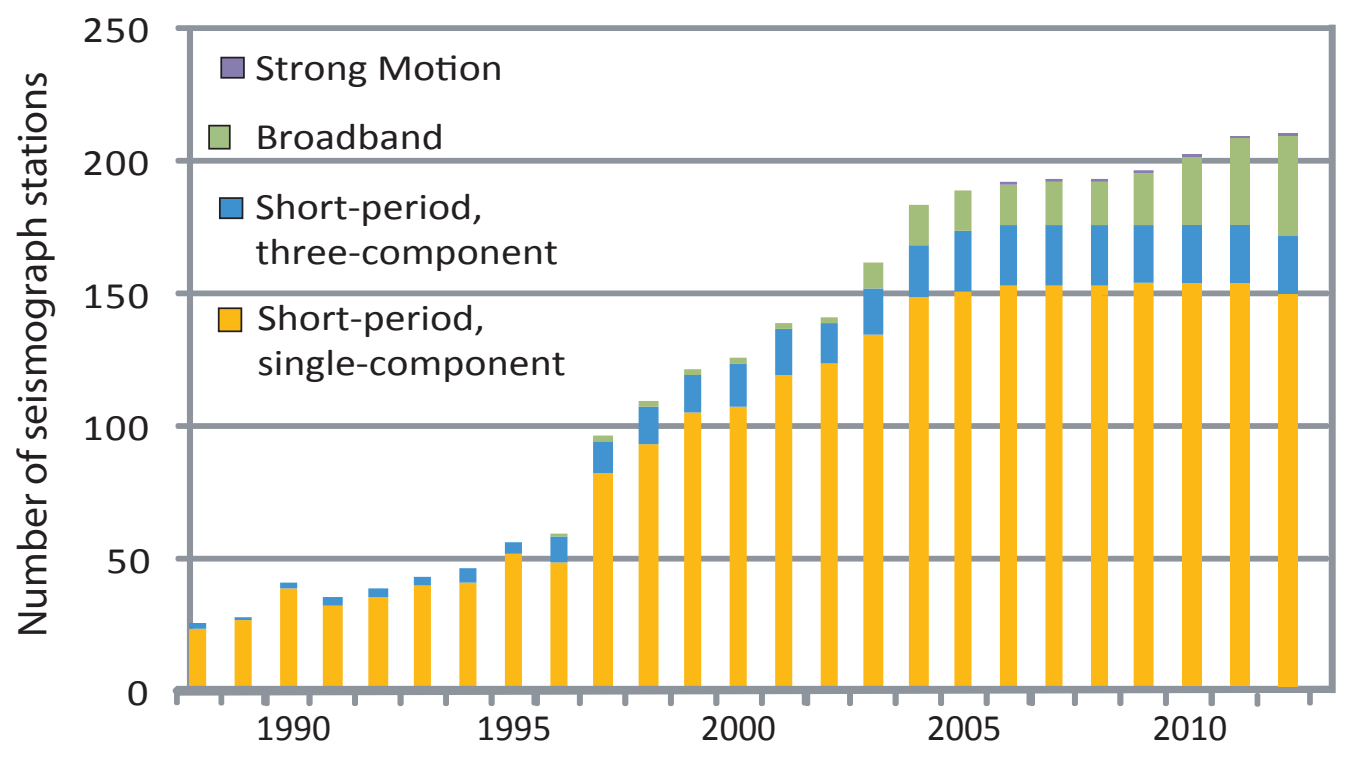

Figure 2. Number of AVO seismograph stations by type and year. 
Table 1. Number of permanent AVO seismograph stations by type and network in 2012.

[Seismograph station details and operational status are available in appendixes B and $\underline{\mathrm{D}}$, respectively]

\begin{tabular}{|c|c|c|c|c|c|c|}
\hline Subnetwork & $\begin{array}{l}\text { Number of } \\
\text { seismograph } \\
\text { stations }\end{array}$ & $\begin{array}{c}\text { Number } \\
\text { of station } \\
\text { components }\end{array}$ & $\begin{array}{l}\text { Number } \\
\text { of single- } \\
\text { component } \\
\text { short-period } \\
\text { stations }\end{array}$ & $\begin{array}{l}\text { Number } \\
\text { of three- } \\
\text { component } \\
\text { short-period } \\
\text { stations }\end{array}$ & $\begin{array}{l}\text { Number } \\
\text { of three- } \\
\text { component } \\
\text { broadband } \\
\text { stations }\end{array}$ & $\begin{array}{c}\text { Number } \\
\text { of three- } \\
\text { component } \\
\text { strong motion } \\
\text { stations }\end{array}$ \\
\hline Akutan & 12 & 29 & 5 & 1 & 7 & 0 \\
\hline Aniakchak & 6 & 8 & 5 & 1 & 0 & 0 \\
\hline Augustine & 9 & 18 & 7 & 1 & 1 & 1 \\
\hline Cerberus & 6 & 8 & 5 & 1 & 0 & 0 \\
\hline Dutton & 5 & 5 & 5 & 0 & 0 & 0 \\
\hline Fourpeaked & 4 & 7 & 4 & 0 & 0 & 0 \\
\hline Gareloi & 6 & 8 & 5 & 1 & 0 & 0 \\
\hline Great Sitkin & 6 & 8 & 5 & 1 & 0 & 0 \\
\hline Iliamna & 6 & 8 & 5 & 1 & 0 & 0 \\
\hline Kanaga & 6 & 6 & 6 & 0 & 0 & 0 \\
\hline Katmai & 20 & 30 & 15 & 3 & 2 & 0 \\
\hline Korovin & 7 & 9 & 6 & 1 & 0 & 0 \\
\hline Little Sitkin & 4 & 6 & 3 & 1 & 0 & 0 \\
\hline Makushin & 7 & 21 & 6 & 1 & 4 & 0 \\
\hline Okmok & 13 & 21 & 9 & 0 & 4 & 0 \\
\hline Pavlof & 7 & 9 & 6 & 1 & 0 & 0 \\
\hline Peulik & 7 & 9 & 6 & 1 & 0 & 0 \\
\hline Redoubt & 12 & 31 & 6 & 2 & 6 & 0 \\
\hline Shishaldin & 7 & 11 & 5 & 1 & 1 & 0 \\
\hline Spurr & 17 & 31 & 10 & 1 & 6 & 0 \\
\hline Tanaga & 6 & 8 & 5 & 1 & 0 & 0 \\
\hline Veniaminof & 9 & 9 & 9 & 0 & 0 & 0 \\
\hline Westdahl & 6 & 8 & 5 & 1 & 0 & 0 \\
\hline Wrangell & 4 & 6 & 3 & 1 & 0 & 0 \\
\hline $\begin{array}{l}\text { Regional } \\
\text { Stations }\end{array}$ & 10 & 12 & 9 & 0 & 1 & 0 \\
\hline Totals & 202 & 326 & 155 & 22 & 32 & 1 \\
\hline
\end{tabular}


Table 2. Number of AVO seismograph stations by type and year.

\begin{tabular}{ccccccc}
\hline Year & $\begin{array}{c}\text { Number of } \\
\text { stations in } \\
\text { the AV0 } \\
\text { seismograph } \\
\text { network }\end{array}$ & $\begin{array}{c}\text { Number of } \\
\text { components } \\
\text { in the AV0 } \\
\text { seismograph } \\
\text { network }\end{array}$ & $\begin{array}{c}\text { Number } \\
\text { of single- } \\
\text { component } \\
\text { short-period } \\
\text { stations }\end{array}$ & $\begin{array}{c}\text { Number } \\
\text { of three- } \\
\text { component } \\
\text { short-period } \\
\text { stations }\end{array}$ & $\begin{array}{c}\text { Number } \\
\text { of three- } \\
\text { component } \\
\text { broadband } \\
\text { stations }\end{array}$ & $\begin{array}{c}\text { Number } \\
\text { of three- } \\
\text { component } \\
\text { strong motion } \\
\text { stations }\end{array}$ \\
\hline 1988 & 25 & 29 & 23 & 2 & 0 & 0 \\
1989 & 28 & 32 & 26 & 2 & 0 & 0 \\
1990 & 42 & 49 & 39 & 3 & 0 & 0 \\
1991 & 36 & 42 & 33 & 3 & 0 & 0 \\
1992 & 39 & 46 & 36 & 3 & 0 & 0 \\
1993 & 44 & 51 & 41 & 3 & 0 & 0 \\
1994 & 47 & 58 & 42 & 5 & 0 & 0 \\
1995 & 57 & 67 & 52 & 5 & 0 & 0 \\
1996 & 60 & 79 & 49 & 10 & 1 & 0 \\
1997 & 92 & 125 & 83 & 12 & 2 & 0 \\
1998 & 108 & 142 & 94 & 14 & 2 & 0 \\
1999 & 121 & 156 & 106 & 14 & 2 & 0 \\
2000 & 125 & 162 & 108 & 16 & 2 & 0 \\
2001 & 138 & 177 & 120 & 17 & 3 & 0 \\
2002 & 140 & 179 & 124 & 16 & 2 & 0 \\
2003 & 160 & 217 & 135 & 18 & 9 & 0 \\
2004 & 182 & 255 & 149 & 20 & 15 & 0 \\
2005 & 188 & 266 & 151 & 23 & 15 & 0 \\
2006 & 190 & 275 & 154 & 23 & 15 & 1 \\
2007 & 193 & 281 & 154 & 22 & 17 & 1 \\
2008 & 193 & 281 & 154 & 22 & 17 & 1 \\
2009 & 196 & 291 & 155 & 22 & 19 & 1 \\
2010 & 200 & 303 & 155 & 22 & 23 & 1 \\
2011 & 201 & 319 & 158 & 22 & 29 & 1 \\
2012 & 202 & 326 & 155 & 22 & 32 & 1 \\
\hline
\end{tabular}

The single-component short-period seismograph stations were equipped with either Mark Products L4 or TeledyneGeotech S13 seismometers with a natural period of 1 Hertz (Hz). The AVO also operated three-component, short-period instruments during 2012. Such sites used Mark Products L22, L4, or S13 seismometers. The L22 seismometer has a natural period of $2 \mathrm{~Hz}$. Broadband stations were operated with either a Guralp CMG-40T seismometer (frequency range: 0.033-50 Hz), Guralp CMG-6TD seismometer (frequency range: $0.033-50 \mathrm{~Hz}$ ), or Nanometrics Trillium 40 seismometer (frequency range: $0.025-50 \mathrm{~Hz}$ ). The Augustine strong motion station (AU22) used a REFTEK 130-ANSS/02 strong motion sensor (frequency range: $\mathrm{DC}-500 \mathrm{~Hz}$ ).
The majority of recordings of short-period stations were digitized at 100 samples per second (sps). The Cerberus and Little Sitkin subnetworks were recorded at $50 \mathrm{sps}$ due to limitations in data rates using very small aperture terminal telemetry between the recording hubs located on Amchitka Island and Anchorage. Broadband stations were digitized at 50 sps with the exception of AUL, which was recorded at 100 sps. Each seismograph station is individually set to record above the noise level at each site and the range of calibration curves for short-period and broadband seismometers used in the AVO network are shown in figures 3 and $\underline{4}$. Calibration information for each station, given in poles and zeros, is found in a metadata file in the form of a dataless SEED volume included in a data supplement to this report. 


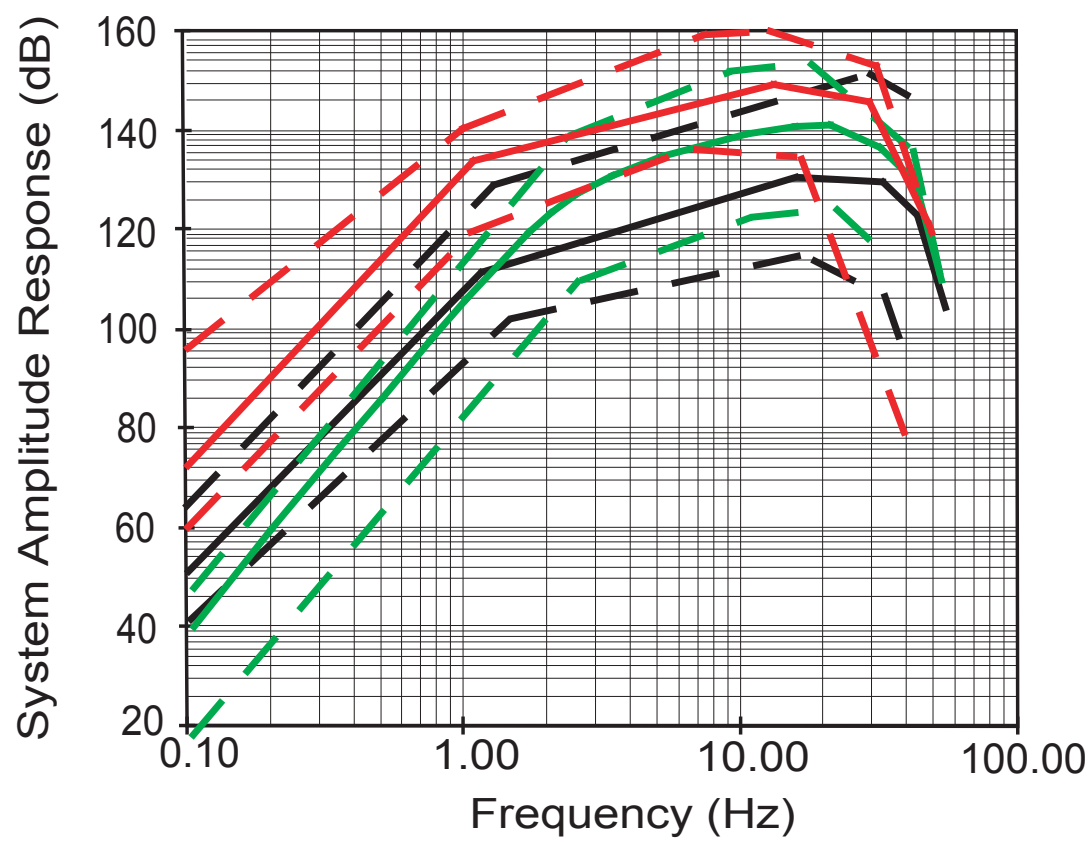

Figure 3. Log-log plot of representative displacement response curves for AVO short-period stations using a L4 (black), S13 (red), or L22 (green) seismometer

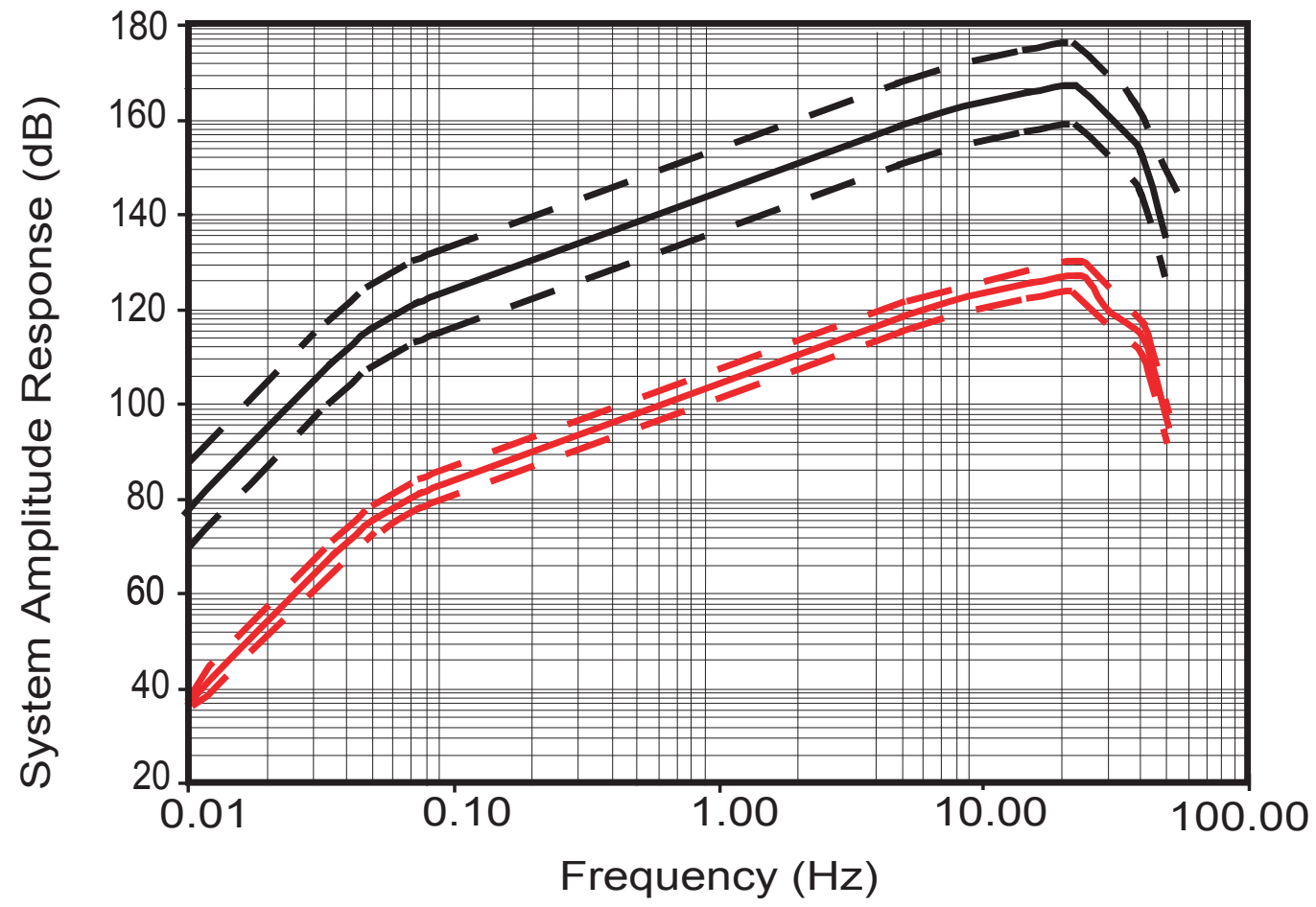

Figure 4. Log-log plot of representative displacement response curves for the AVO broadband stations using a CMG-6TD (black) or CMG-40T (red) seismometer. Solid lines indicate the typical curve and dashed lines show the range of curves for all AVO stations using the same seismometer. 
Data from short-period seismograph stations were telemetered using voltage-controlled oscillators (VCOs) to transform the signals generated by the seismometer from a voltage to a frequency-modulated carrier suitable for transmission over a radio link or telephone circuit. AVO uses VCOs developed by McChesney (1999) to modulate signals in the field with one exception: seismograph station NCG used an A1VCO (Rogers and others, 1980). Signals were transmitted via UHF and VHF radio to communication hubs located in Adak, Akutan, Amchitka Island, Anchorage, Atka, Cold Bay, Homer, Kenai, King Cove, King Salmon, Port Heiden, Sourdough, and Unalaska (fig. 1).

Data were digitized at the Adak, Amchitka Island, Homer, Kenai, King Salmon, and Unalaska communication hubs and directed to AVO offices via high-speed digital circuits. From all other hubs (Akutan, Cold Bay, Port Heiden, Sourdough, and Tolsona), analog signals were relayed via leased telephone circuits to AVO offices in Anchorage or Fairbanks where the signals were subsequently digitized. Data from broadband seismograph stations were digitized at the station site and transmitted digitally using spread spectrum radios to communication hubs in Akutan, Anchorage, Homer, and King Salmon, and Unalaska. These data were forwarded to AVO offices in Fairbanks and Anchorage via high-speed digital circuits.

Earthquakes at volcanic centers located in 2012 with the AVO seismograph network are shown in appendix A. Locations for all AVO stations are contained in appendix B with maps showing the locations of stations with respect to individual volcanoes in appendix C. Each station's operational status for the catalog period is shown in appendix D and uses the Incorporated Research Institutions for Seismology

(IRIS) Gap/Overlap Analysis Tool (Stromme, 2000). A list of earthquakes located in 2012 in which a description of the data in the summary listing also is shown in appendix E.

\section{Data Acquisition and Processing}

Data acquisition for the AVO seismograph network at the beginning of the year was accomplished with an EARTHWORM system (Johnson and others, 1995), processed with the interactive seismic data analysis program XPICK (Robinson, 1990) and located with HYPOELLIPSE (Lahr, 1999). On February 1, 2012, the data acquisition and processing was migrated to the Advanced National Seismic System (ANSS) Quake Monitoring System (AQMS). AQMS is an integrated data acquisition and processing system that uses EARTHWORM for data acquisition and preliminary processing with JIGGLE (U.S. Geological Survey, 2013) used for data analysis. Earthquake locations were found using HYPOINVERSE (Klein, 2002).

Data were recorded in both continuous and event detection modes. Although a change in data processing occurred in February, the input parameters for the EARTHWORM event detection modules did not change. Event detected data for both data acquisition systems were collected using the EARTHWORM modules Carlstatrig and Carlsubtrig, with the Carlstatrig parameters set as follows: Long-term-average (LTA) time $=8$ seconds, Ratio $=2.3$, and Quiet $=4$. Three station triggers from the Carlstatrig module are required for an event to trigger Carlsubtrig to create an event record. Carlsubtrig was modified such that each triggered record is identified with the triggering network. For January, this was accomplished by appending a two-letter code (table 3) to the filename of each trigger to identify the first subnetwork that triggered. For February through December, the volcano subnetwork name associated with the trigger was saved in the database instead of the two-letter code. If four or more subnetworks triggered on the same event, all data were saved in a single trigger and tagged as a regional event ("re" in January and "regional" in February-December). Using custom programs written by Instrumental Software Technologies Inc., all triggered events from January were inserted into the

Table 3. Volcano subnetwork designators.

\begin{tabular}{|c|c|c|}
\hline $\begin{array}{c}\text { Volcano } \\
\text { subnetwork }\end{array}$ & $\begin{array}{l}\text { Network } \\
\text { code }\end{array}$ & Volcanoes monitored \\
\hline Akutan & ak & Akutan Peak \\
\hline Aniakchak & an & Aniakchak Crater \\
\hline Augustine & $\mathrm{au}$ & Augustine Volcano \\
\hline Cerberus & ce & Mount Cerberus \\
\hline Dutton & $\mathrm{dt}$ & Mount Dutton \\
\hline Iliamna & il & Iliamna Volcano \\
\hline Fourpeaked & fo & Fourpeaked Mountain \\
\hline Gareloi & ga & Mount Gareloi \\
\hline Great Sitkin & gs & Great Sitkin Volcano \\
\hline Kanaga & ki & Kanaga Volcano \\
\hline Katmai & ka & $\begin{array}{l}\text { Mount Griggs, Mount Katmai, } \\
\text { Mount Mageik and Mount } \\
\text { Martin, Novarupta, Snowy } \\
\text { Mountain, and Trident Volcano }\end{array}$ \\
\hline Korovin & ko & Korovin Volcano \\
\hline Little Sitkin & ls & Little Sitkin Volcano \\
\hline Makushin & ma & Makushin Volcano \\
\hline Okmok & ok & Okmok Caldera \\
\hline Pavlof & $\mathrm{pv}$ & Pavlof Volcano \\
\hline Peulik & $\mathrm{pl}$ & Ugashik-Peulik and Ukinrek Maars \\
\hline Redoubt & rd & Redoubt Volcano \\
\hline Shishaldin & $\mathrm{sh}$ & $\begin{array}{l}\text { Fisher Caldera, Isanotski Peaks, and } \\
\text { Shishaldin Volcano }\end{array}$ \\
\hline Spurr & $\mathrm{sp}$ & Mount Spurr \\
\hline Tanaga & ta & Tanaga Volcano \\
\hline Veniaminof & vn & Mount Veniaminof \\
\hline Westdahl & we & Fisher Caldera, and Westdahl Peak \\
\hline Wrangell & wa & Mount Wrangell \\
\hline
\end{tabular}


database. All triggered data are stored in mini-SEED format (SEED Manual, 2010). Prior to February 2012, all data are saved in Seismic Analysis Code (SAC) format (Goldstein and others, 1999).

Event triggers were processed daily in 2012. Each event trigger was visually inspected and false triggers were deleted. Earthquakes with a P-wave and S-wave separation of greater than 5 seconds on the closest station were assumed to come from non-volcanic sources and typically were not located but the triggered data were preserved. Each hypocenter meets the following minimum parameters: three P-phases, two S-phases, and standard hypocentral errors less than $15 \mathrm{~km}$. If upon reevaluation, the minimum parameters could not be met, the event was removed from the final catalog listing. The average root-mean-square (RMS) travel-time error for earthquakes located in 2012 was 0.15 seconds and the average vertical and horizontal hypocentral errors were 1.2 and $2.1 \mathrm{~km}$, respectively. For the earthquakes appearing in the 2012 AVO catalog, 95 percent of the earthquakes had an average rootmean-square travel-time error less than 0.36.

At the time of this report's publication, all hypocentral locations of earthquakes in the AVO seismic catalog have been made available as part of the Advanced National Seismic System (ANSS) catalog (Advanced National Seismic System, 2013) ) and are currently being added on a daily basis to the ANSS catalog. Continuous waveform data for the majority of AVO seismograph stations, whose availability is displayed using IRIS's Gap/Overlap Analysis Tool (appendix D), are archived and available through IRIS (http://www.iris.edu/ hq/). All continuous data are available for in-house use on WINSTON and ANTELOPE systems. Archives of waveform data for 2002-10 are maintained on DVD-ROM at AVO offices.

The AVO seismograph station data are used by both the $\mathrm{AVO}$ and the Alaska Earthquake Information Center (AEIC). Twenty percent of the earthquakes located by AVO also are located by AEIC. Any earthquake that is co-located by both AVO and AEIC is assigned the AEIC location in the ANSS catalog.

Additional data from seismograph stations operated by AEIC, Global Seismograph Network (GSN), and West Coast and Alaska Tsunami Warning Center (WCATWC) were routinely utilized in event detection and location. Station parameters for the AEIC, GSN, and WCATWC stations used by AVO in 2012 are provided in appendix B.

\section{Seismic Velocity Models}

During 2012, AVO used 13 local volcano-specific seismic velocity models and a regional seismic velocity model to locate earthquakes at Alaskan volcanoes. All velocity models were one-dimensional models utilizing horizontal layers to approximate the local seismic velocity structure. Each model, with one exception, assumed a series of constant velocity layers. The single exception was the Akutan velocity model (Power and others, 1996), which had a velocity gradient in a layer overlying a half-space of constant velocity.

One or more vertical cylindrical volumes were used to model the volcanic source zones for all volcanoes where a local velocity model was used. Earthquakes within these cylindrical volumes were located using a local model and earthquakes outside of the cylindrical volumes were located using the regional model. The top of each cylinder was set at $3 \mathrm{~km}$ above sea level and the bottom was set at a depth of $50 \mathrm{~km}$ below sea level. All cylindrical volumes had a radius of $20 \mathrm{~km}$ with the exception of the cylinders centered on Shishaldin and Mount Veniaminof. The cylinder centered on Shishaldin had a radius of $30 \mathrm{~km}$ in order to encompass Fisher Caldera and Isanotski Peaks. The cylinder centered on Veniaminof also had a radius of $30 \mathrm{~km}$ because of the large size of the volcanic edifice.

The Akutan, Augustine (Power, 1988), Iliamna (Roman and others, 2001), Makushin (Searcy, written commun., 2010), Okmok (Masterlark and others, 2010), Tanaga (J.A. Power, written commun., 2005), Veniaminof (Sánchez, 2005) and Westdahl (Dixon and others, 2005) velocity models were used to locate hypocenters that fell within cylindrical volumes described above, centered on each respective volcano. Five overlapping cylinders defined the volume in which the Spurr velocity model (Jolly and others, 1994) was used, four overlapping cylinders defined the volume for the Redoubt velocity model (Lahr and others, 1994), and four overlapping cylinders defined the volume for the Katmai model (Searcy, 2003). The Andreanof velocity model, modified from that in Toth and Kisslinger (1984), was used to locate earthquakes within a volume defined by three cylinders centered on Kanaga Volcano, Mount Moffet, and Great Sitkin Volcano. The Cold Bay velocity model (McNutt and Jacob, 1986) was used to locate earthquakes that fell within cylindrical volumes centered on Mount Dutton, Pavlof Volcano, and Shishaldin Volcano. Earthquakes located at Fisher and Isanotski fell within the cylindrical volume centered on Shishaldin Volcano. Specific velocity models for Aniakchak Crater, Mount Cerberus, Fourpeaked Mountain, Mount Gareloi, Korovin Volcano, Little Sitkin Volcano, Mount Peulik, and Mount Wrangell were not available in 2012 and the regional velocity model (Fogleman and others, 1993) was used to locate earthquakes near these volcanoes. The cylindrical model parameters, regional velocity model, and volcanospecific models used to locate earthquakes in this report are summarized in appendix F. Figures showing the volcanic source zones modeled by multiple cylinders are shown in appendix G. HYPOINVERSE was modified to allow for the identical implementation of these velocity models as they had been in HYPOELLIPSE. 


\section{Seismicity}

In 2012, the AVO located 4,787 earthquakes at the 33 volcanic centers with seismograph subnetworks (fig. 5, appendix A), which represents an increase from the 4,364 earthquakes located in 2011 (Dixon and others, 2012). Of the earthquakes located in 2012, 87 percent (4,211 earthquakes) were located within $20 \mathrm{~km}$ of a monitored volcanic center. The numbers of located earthquakes associated with volcanic centers during the last 2 years are shown in table 4 . The numbers of located earthquakes in the AVO catalog by year are shown in figure 5 and table 5.

Using the 2012 earthquake catalog, the magnitude of completeness (Mc) for each subnetwork was calculated with the exception of four subnetworks (table 4). The Gareloi, Pavlof, Veniaminof, and Wrangell subnetworks had insufficient numbers of located earthquakes to calculate a Mc. $\mathrm{Mc}$ is the magnitude threshold above which we are reasonably certain that an event of Mc or greater was detected. The Mc was determined using a maximum likelihood estimate of the inflection point in the frequency magnitude distribution using the seismology analysis software ZMAP (Wiemer, 2001). The Mc ranged from -0.7 to 1.7 for the individual subnetworks.
The seismicity at the monitored volcanoes showed few deviations from the background level of seismicity. Aniakchak, Fourpeaked, Iliamna, and Little Sitkin were the only volcanic centers in which the number of located earthquake indicated increases over the background levels. A small explosive event at Kanaga and a short burst of seismicity at Mount Spurr did not have a corresponding increase in the number of located earthquakes compared to last year because the episodes of elevated seismicity were brief. The seismicity at the remainder of volcanoes monitored by seismograph networks was within background rates of seismicity for that network.

Starting in 2011, the located seismicity at Aniakchak increased over the established background seismicity as a result of small bursts of activity, typically composed of deep (greater than $10 \mathrm{~km}$ ) low-frequency earthquakes. This trend continued into 2012 with four bursts of activity (February 7, March 29-April 4, October 22, December 21). An additional dozen instances in which earthquakes occurred but were not located because of station failures were noted in daily seismicity reports. No migration of earthquake hypocenters was noted in 2012.

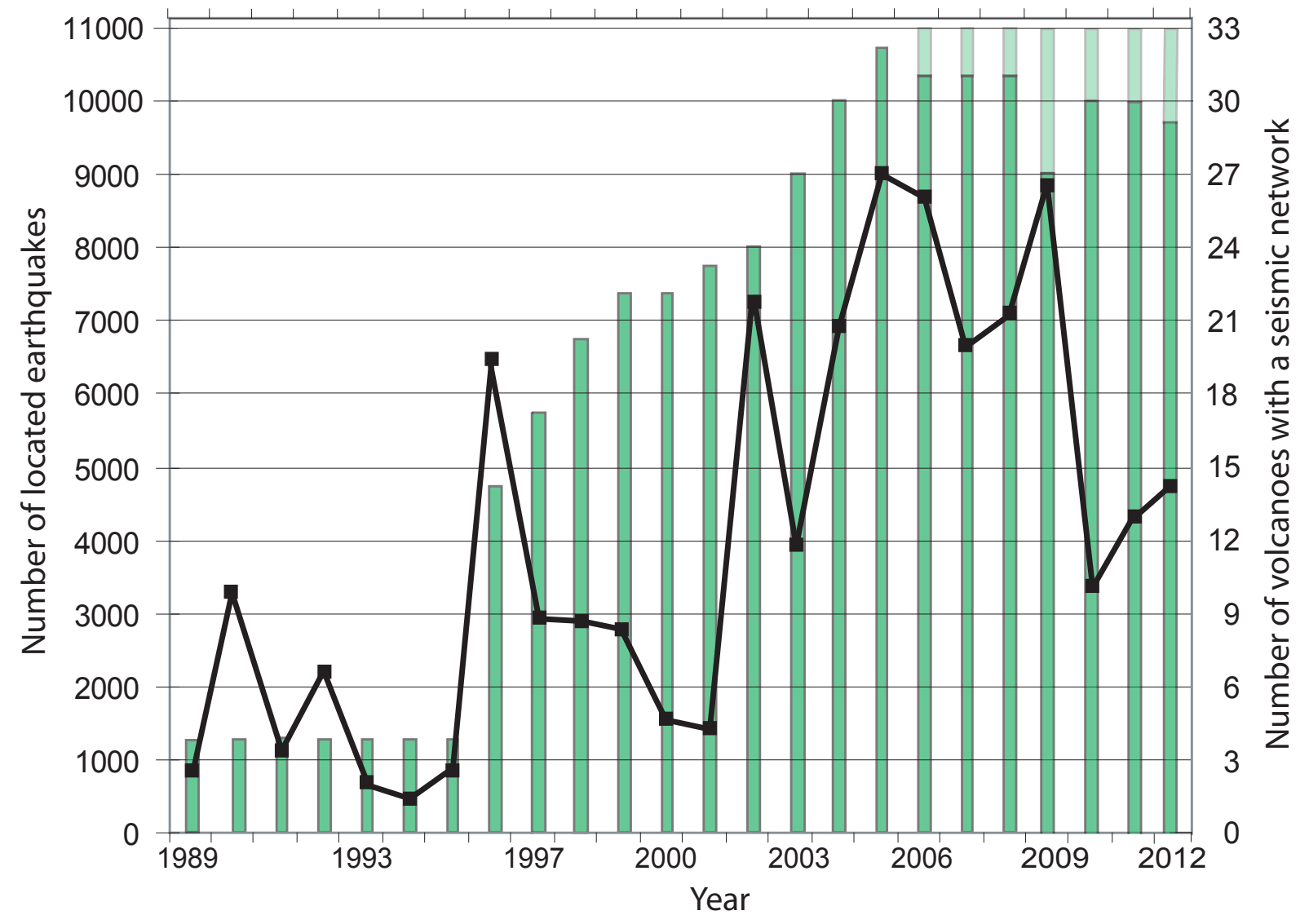

Figure 5. Number of earthquakes located per year in the AVO catalog (black line) and number of volcanoes with a seismic network per year (green bars). The lighter green color indicates the number of volcanoes with seismic networks and not included on the formal list of monitored volcanoes. 
Table 4. Number of earthquakes located for each seismograph subnetwork in 2012 within $20 \mathrm{~km}$ of the volcanic centers in each subnetwork.

[The totals for 2012 are broken into three event types: volcanic-tectonic (VT), low-frequency (LF) and other (all other possible event types shown in table 1 of appendix E). Magnitude of completeness (Mc) for AVO seismograph subnetworks using data from 2012 and the period March $2002-$ December 2012]

\begin{tabular}{|c|c|c|c|c|c|c|c|}
\hline $\begin{array}{c}\text { Volcano } \\
\text { subnetwork }\end{array}$ & $\begin{array}{l}\text { Earthquakes } \\
\text { located in } 2011\end{array}$ & $\begin{array}{l}\text { Earthquakes } \\
\text { located in } 2012\end{array}$ & $\begin{array}{c}2012 \\
\text { VT }\end{array}$ & $\begin{array}{c}2012 \\
\text { LF }\end{array}$ & $\begin{array}{l}2012 \\
\text { Other }\end{array}$ & $\begin{array}{c}2012 \\
\text { Mc }\end{array}$ & $\begin{array}{c}2002-2012 \\
\text { Mc }\end{array}$ \\
\hline Akutan & 77 & 42 & 24 & 18 & 0 & 1.1 & 0.3 \\
\hline Aniakchak & 55 & 40 & 8 & 32 & 0 & 0.5 & 1.4 \\
\hline Augustine & 48 & 54 & 54 & 0 & 0 & -0.1 & 0.0 \\
\hline Cerberus & 0 & 14 & 7 & 5 & 2 & 0.8 & 1.0 \\
\hline Dutton & 32 & 12 & 11 & 1 & 0 & 0.7 & 1.0 \\
\hline Fourpeaked & 90 & 123 & 120 & 2 & 1 & 1.5 & 0.4 \\
\hline Gareloi & 23 & 16 & 16 & 0 & 0 & - & 1.2 \\
\hline Great Sitkin & 25 & 24 & 24 & 0 & 0 & -0.7 & 0.6 \\
\hline Iliamna & 54 & 738 & 700 & 58 & 0 & 0.0 & -0.4 \\
\hline Kanaga & 21 & 52 & 45 & 7 & 0 & 0.1 & 1.2 \\
\hline Katmai Cluster & 1,288 & 824 & 804 & 19 & 1 & 0.3 & 0.5 \\
\hline Korovin & 117 & 22 & 16 & 6 & 0 & 0.9 & 0.7 \\
\hline Little Sitkin & 0 & 1,050 & 1,028 & 6 & 16 & 0.0 & 0.0 \\
\hline Makushin & 198 & 234 & 216 & 18 & 0 & 0.2 & 0.7 \\
\hline Okmok & 23 & 33 & 24 & 9 & 0 & 1.7 & 0.9 \\
\hline Pavlof & 13 & 4 & 1 & 3 & 0 & - & 1.0 \\
\hline Peulik & 34 & 59 & 57 & 2 & 0 & 1.2 & 0.9 \\
\hline Redoubt & 162 & 154 & 121 & 33 & 0 & 0.0 & 0.3 \\
\hline Shishaldin & 591 & 64 & 6 & 58 & 0 & 0.6 & 0.6 \\
\hline Spurr & 531 & 496 & 294 & 202 & 0 & 0.6 & 0.2 \\
\hline Tanaga & 106 & 65 & 65 & 0 & 0 & 1.1 & 1.1 \\
\hline Veniaminof & 7 & 13 & 1 & 12 & 0 & - & 1.3 \\
\hline Westdahl & 156 & 58 & 39 & 19 & 0 & 0.9 & 1.1 \\
\hline Wrangell & 0 & 0 & 0 & 0 & 0 & - & 0.9 \\
\hline Totals & 3,651 & 4,211 & 3,681 & 510 & 20 & - & - \\
\hline
\end{tabular}

The Fourpeaked network saw a substantial increase in number of earthquakes. A decrease in the located earthquakes would be expected because the magnitude of completeness increased from 0.6 in 2011 to 1.5 in 2012, but there was an increase by one-third in the number of located earthquakes. The increase in the magnitude of completeness is a direct result of substantial outages in the last 6 months of the year. Most of the detected activity occurred in the last 6 months of the year where there were four short swarms of activity lasting 3-5 days with an average of 17 earthquakes in each period (August 19-22, October 6-10, November 23-25, and December 12-16). The earthquakes located in 2012 occur in an area that has had little seismicity since the establishment of the Fourpeaked network. The network outages could have influenced the location of the hypocenters in an area with previously located earthquakes with a bias towards seismograph station CDD, north of Fourpeaked Mountain and northwest of Mount Douglas. Had the network outages not occurred, a much greater number of earthquakes would have been located.

The volcanic alert level for Kanaga was raised to ADVISORY on February 18 when volcanic tremor was noted in conjunction with a short earthquake swarm, resulting in a minor ash emission. The elevated seismicity died away by February 20, with a minor increase in seismicity on February 24. There was no other activity at Kanaga Volcano and the volcano alert level was reduced to NORMAL on March 2. On March 5, satellite imagery showed a new fracture on the south rim of the summit crater (fig. 6). 
Table 5. Number of earthquakes located per year in the AVO earthquake catalog.

\begin{tabular}{|c|c|c|c|}
\hline Year & $\begin{array}{l}\text { Number of earthquakes } \\
\text { located per year }\end{array}$ & $\begin{array}{l}\text { Number of earthquakes } \\
\text { located per year within } \\
20 \text { kilometers of a volcano }\end{array}$ & $\begin{array}{l}\text { Volcanoes with an AVO } \\
\text { seismograph network }\end{array}$ \\
\hline 1989 & 911 & 892 & 4 \\
\hline 1990 & 3,285 & 3,148 & 4 \\
\hline 1991 & 1,119 & 1,064 & 4 \\
\hline 1992 & 2,184 & 2,104 & 4 \\
\hline 1993 & 697 & 592 & 4 \\
\hline 1994 & 441 & 407 & 4 \\
\hline 1995 & 850 & 760 & 4 \\
\hline 1996 & 6,466 & 4,259 & 14 \\
\hline 1997 & 2,930 & 1,783 & 17 \\
\hline 1998 & 2,873 & 1,886 & 20 \\
\hline 1999 & 2,769 & 2,343 & 22 \\
\hline 2000 & 1,551 & 1,225 & 22 \\
\hline 2001 & 1,427 & 1,122 & 23 \\
\hline 2002 & 7,242 & 6,578 & 24 \\
\hline 2003 & 3,911 & 3,264 & 27 \\
\hline 2004 & 6,928 & 6,105 & 30 \\
\hline 2005 & 9,012 & 8,146 & 32 \\
\hline 2006 & 8,666 & 7,782 & 33 \\
\hline 2007 & 6,664 & 5,660 & 33 \\
\hline 2008 & 7,097 & 5,318 & 33 \\
\hline 2009 & 8,829 & 7,438 & 33 \\
\hline 2010 & 3,405 & 2,846 & 33 \\
\hline 2011 & 4,364 & 3,651 & 33 \\
\hline 2012 & 4,787 & 4,211 & 33 \\
\hline
\end{tabular}

14 January 2012

05 March 2012

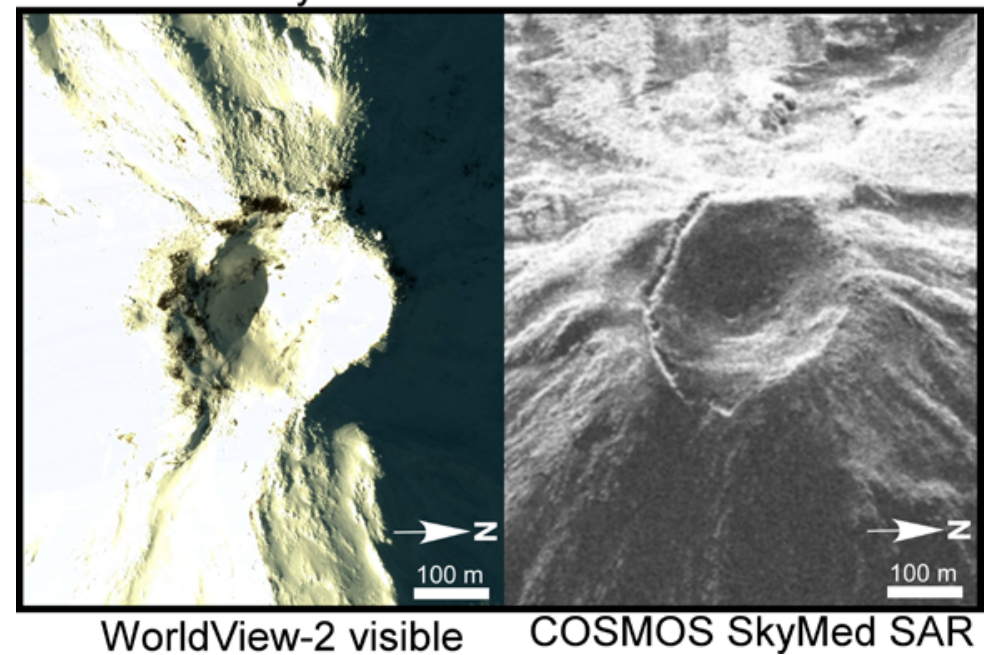

Figure 6. Satellite views of the summit crater of Kanaga Volcano (north is rotated to the right). The left visible WorldView-2 view shows the crater with a few steaming fumaroles along the southern edge before the explosive activity in February. The right view shows COSMOS SkyMed SAR data revealing a recent fracture along the southern edge of the crater after the February activity. 
In the first months of the year, the earthquake rate at Iliamna Volcano steadily increased and at the end of February the number of located earthquakes was about ten times the annual rate. The located volcanic-tectonic earthquake rate showed an additional four-fold increase in March with a corresponding increase in observed low frequency events. This high seismicity rate corresponded with increased magmatic degassing based on gas studies and suggests a magmatic intrusion was likely (Prejean and others, 2012). In response to this activity, the volcano alert level was raised to ADVISORY on March 9. By April, the number of located events was down significantly but remained slightly above background through the end of the year. Station outages in the summer months, reduced the number of earthquakes located but there was no indication that the seismicity approached that of early March. The seismicity was similar to a swarm in 1996-97, which was interpreted to be driven by magmatic intrusion (Roman and others, 2004) although the earlier swarm did not include the low-frequency earthquakes seen in the 2012 swam.

A volcano-tectonic earthquake swarm began at Little Sitkin on August 29 following a week-long period of lowlevel anomalous seismic activity. This anomalous seismicity consisted of 2-3 Hz monochromatic signals, $0.6 \mathrm{~Hz}$ monochromatic signals, and tremor episodes. The volcano alert level was raised to ADVISORY in response to this increase in activity on August 30. The $0.6 \mathrm{~Hz}$ monochromatic signals occurred prior to the swarm, between August 23-25, and were clearly observed over $80 \mathrm{~km}$ away at Amchitka and Semisopochnoi and are similar to earthquakes seen at Izu-Ooshima Volcano (Ukawa and Ohtake, 1987). Volcanotectonic events, $2-3 \mathrm{~Hz}$ monochromatic signals and spasmodic bursts [a series of closely spaced earthquakes lasting 5-10 minutes as described by Hill and others (1990)] characterized this anomalous seismicity. The seismicity during the next 3 months consisted of increasingly less frequent $2-3 \mathrm{~Hz}$ monochromatic signals with several brief swarms of volcanictectonic events and spasmodic bursts. The final observation of anomalous seismicity was on December 22 and the volcano alert level for Little Sitkin was reduced to NORMAL on January 9, 2013.

A minor increase in seismicity occurred on June 25 at Mount Spurr, resulting in the release of an information statement. The character of the seismicity recorded was consistent with the seismic energy generated by an energetic flow of water, possibly a glacier outburst. Within hours of onset, seismic levels decreased to near background and no additional flowage signals were observed in 2012.

\section{Summary}

Between January 1 and December 31, 2012, the Alaska Volcano Observatory (AVO) located 4,787 earthquakes, of which 4,211 occurred within 20 kilometers of the 33 volcanoes with seismograph subnetworks. There was significant seismic activity at three volcanoes in 2012-Iliamna, Kanaga, and Little Sitkin volcanoes. Instrumentation highlights for 2012 were the implementation of the AQMS hardware and software in February and the continuation of the American Recovery and Reinvestment Act work in the summer of 2012. The operational highlight was the removal of Mount Wrangell from the list of monitored volcanoes. This catalog includes locations, magnitudes, and statistics of the earthquakes located in 2012 with the station parameters, velocity models, and other files used to locate these earthquakes.

Available for download with this report is a compressed file containing a summary listing of earthquake hypocenters and all necessary files to recalculate the hypocenters including station locations and calibrations, seismic velocity models, and phase information. A metadata file in the form of a dataless SEED volume for the AVO Seismograph network is included in the data supplement. The reader should refer to Lahr (1999) and Klein (2002) for information on file formats and instructions for configuring and running the location programs HYPOELLIPSE and HYPOINVERSE, respectively. Continuous waveform data for the majority of AVO seismograph stations, whose availability is displayed using IRIS's Gap/Overlap Analysis Tool (appendix D), are archived and available through IRIS (http://www.iris.edu/hq/). Archives of waveform data for 2002-10 are maintained on DVD-ROM at AVO offices.

AVO earthquake catalogs for 1989-2011 are listed in appendix H. Selected papers published in 2012 that utilized AVO seismic data are listed in appendix I.

\section{Acknowledgments}

The contents of this report reflect a great deal of hard work by a large number of people including AVO, Alaska Earthquake Information Center (AEIC), and USGS personnel and various students, interns, and volunteers. We thank the AEIC and the West Coast and Alaska Tsunami Warning Center for the use of their data. We thank Helena Buurman of the University of Alaska Fairbanks, John Lyons of the U.S. Geological Survey, and Ken Macpherson of the University of Alaska Fairbanks for formal reviews of the text and figures. 


\section{References Cited}

Advanced National Seismic System, 2013, Composite earthquake catalog: website, accessed June 5, 2013, at http:/quake.geo.berkeley.edu/cnss/.

Dixon, J.P., Power, J.A., and Stihler, S.D., 2005, Seismic observations of Westdahl Volcano and Western Unimak Island, Alaska: 1999-2005 [abs.]: American Geophysical Union Transactions, v. 86, Fall Meeting Supplement, Abstract S11b-0169.

Dixon, J.P., and Stihler, S.D., Power, J.A., and Searcy, Cheryl, 2012, Catalog of earthquake hypocenters at Alaskan Volcanoes: January 1 through December 31, 2010: U.S. Geological Survey Data Series 645, 82 p.

Fogleman, K.A., Lahr, J.C., Stephens, C.D., and Page, R.A., 1993, Earthquake locations determined by the southern Alaska seismograph network for October 1971 through May 1989: U.S. Geological Survey Open-File Report 93-309, $54 \mathrm{p}$.

Goldstein, P., Dodge, D., and Firpo, M., 1999, SAC2000: Signal processing and analysis tools for seismologists and engineers, in Lee, W.H.K., Kanamori, H., Jennings, P.P., Kisslinger, C., eds., International Handbook of Engineers and Engineering Seismology, v. 81B, San Diego, Calif., Academic Press, p. 1613-1614.

Hill, D.P., Ellsworth, W.L., Johnston, M.J.S., Langbein, J.O., Oppenheimer, D.H., Pitt, A.M., Reasenberg, P.A., Sorey, M.L., and McNutt, S.R., 1990, The 1989 earthquake swarm beneath Mammoth Mountain, California; an initial look at the 4 May through 30 September activity, Bulletin of the Seismological Society of America, v. 80, no. 2, p. 325- 339.

Johnson, C.E., Bittenbinder, A., Bogaert, D., Dietz, L., and Kohler, W., 1995, EARTHWORM: A flexible approach to seismograph network processing: Incorporated Research Institutions for Seismology Newsletter, v. 14, no. 2, p. 1-4.

Jolly, A.D., Page, R.A., and Power, J.A., 1994, Seismicity and stress in the vicinity of Mt. Spurr volcano, south-central Alaska: Journal of Geophysical Research, v. 99, p. 1530515318.

Klein, F.W., 2002, User's Guide to HYPOINVERSE-2000, a Fortran program to solve for earthquake locations and magnitudes: U.S. Geological Survey Open-File Report 02-171, $123 \mathrm{p}$.

Lahr, J.C., 1999, HYPOELLIPSE: A computer program for determining local earthquake hypocentral parameters, magnitude, and first motion pattern: U.S. Geological Survey Open-File Report 99-23, 116 p.
Lahr, J.C., Chouet, B.A., Stephens, C.D., Power, J.A., and Page, R.A., 1994, Earthquake classification, location, and error analysis in a volcanic environment: Implications for the magmatic system of the 1989-90 eruptions at Redoubt Volcano, Alaska: Journal of Volcanology and Geothermal Research, v. 62, p. 137-152.

Masterlark, T., Haney, M., Dickinson, H., Fournier, T., and Searcy, C., 2010, Rheological and structural controls on the deformation of Okmok Volcano, Alaska: FEM's InSAR, and ambient noise tomography: Journal of Geophysical Research, v. 115, B2, doi:10.1029/2009JB006324.

McChesney, P.J., 1999, McVCO Handbook 1999: U.S. Geological Survey Open-File Report 99-361, 48 p.

McNutt, S.R., and Jacob, K.H, 1986, Determination of largescale velocity structure of the crust and upper mantle in the vicinity of Pavlof Volcano, Alaska: Journal of Geophysical Research, v. 91, p. 5013-5022.

Power, J.A., 1988, Seismicity associated with the 1986 eruption of Augustine Volcano, Alaska: Fairbanks, University of Alaska Fairbanks, M.S. Thesis, 149 p.

Power, J.A., Paskievitch, J.F., Richter, D.H., McGimsey, R.G., Stelling, P., Jolly, A.D., and Fletcher, H.J., 1996, 1996 seismicity and ground deformation at Akutan Volcano: American Geophysical Union Transactions, v. 77, p. F514.

Prejean, S.G., Werner, C.A., Buurman, H., Doukas, M.P., Kelly, P.J., Kern, C., Ketner, D., Stihler, S., Thurber, C.H., and West, M.E., 2012 Seismic and gas analyses imply magmatic intrusion at Iliamna Volcano, Alaska in 2012 [abs]: American Geophysical Union, Fall Meeting, Abstract V53B-2826 San Francisco, Calif. December 3-7, 2012.

Robinson, M., 1990, XPICK user manual, version 2.7: University of Alaska Fairbanks, Seismology Lab, Geophysical Institute, $93 \mathrm{p}$.

Rogers, J.A., Maslak, S., and Lahr, J.C., 1980, A seismic electronic system with automatic calibration and crystal reference: U.S. Geological Survey Open-File Report 80-324, 48 p.

Roman, D.C., Power, J.A., Moran, S.C., Cashman, K.V., and Stihler, S.D., 2001, Unrest at Iliamna Volcano, Alaska in 1996, Evidence for a magmatic intrusion: [abs.]: American Geophysical Union Transactions, v. 82, p. F1329.

Roman, D.C., Power, J.A., Moran, S.C., Cashman, K.V., Doukas, M.P., Neal, C.A., and Gerlach, T.M, 2004, Evidence for dike emplacement beneath Iliamna volcano, Alaska in 1996: Journal of Volcanology and Geothermal Research, v. 130, p. 265-284. 
Sánchez, J.J., 2005, Volcano seismology from around the World: Case studies from Mount Pinatubo (Philippines), Galeras (Columbia), Mount Wrangell and Mount Veniaminof (Alaska): Fairbanks, University of Alaska Fairbanks, Ph.D. dissertation, 208 p.

Schaefer, J.R., Cameron, C.E., and Nye, C.J., 2009, Historically active volcanoes of Alaska: Alaska Division of Geological and Geophysical Surveys Miscellaneous Publication 133, 1 sheet, scale 1:3,000,000.

Searcy, C.K., 2003, Station corrections for the Katmai Region seismograph network: U.S. Geological Survey Open-File Report 03-403, $16 \mathrm{p}$.

SEED Manual, 2010, Standard for the Exchange of Earthquake Data, Reference Manual: SEED Format Version 2.4, Incorporation Research Institution for Seismology, $212 \mathrm{p}$.

Stromme, Sandy, 2000, Gap/Overlap Analysis Tool (GOAT): Incorporated Research Institutions for Seismology DMS Newsletter, v. 2, no. 1.
Toth, T., and Kisslinger, C., 1984, Revised focal depths and velocity model for local earthquakes in the Adak seismic zone: Bulletin of the Seismological Society of America, v. 74 , p. $1349-1360$.

Ukawa, M., and Ohtake, M., 1987, A monochromatic earthquake suggesting deep-seated magmatic activity beneath the Izu-Ooshima Volcano: Journal of Geophysical Research, v. 92, p. 12649-12663.

U.S. Geological Survey, 2013, Jiggle-A graphical earthquake analysis tool: website, accessed June 5, 2013, at http:// pasadena.wr.usgs.gov/jiggle/.

Wiemer, S., 2001, A software package to analyze seismicity: ZMAP: Seismological Research Letters, v. 72, p. 373-382. 
This page left intentionally blank 


\section{Appendix A. Maps of Monitored Volcanoes with Earthquake Hypocenters Calculated in 2012.}
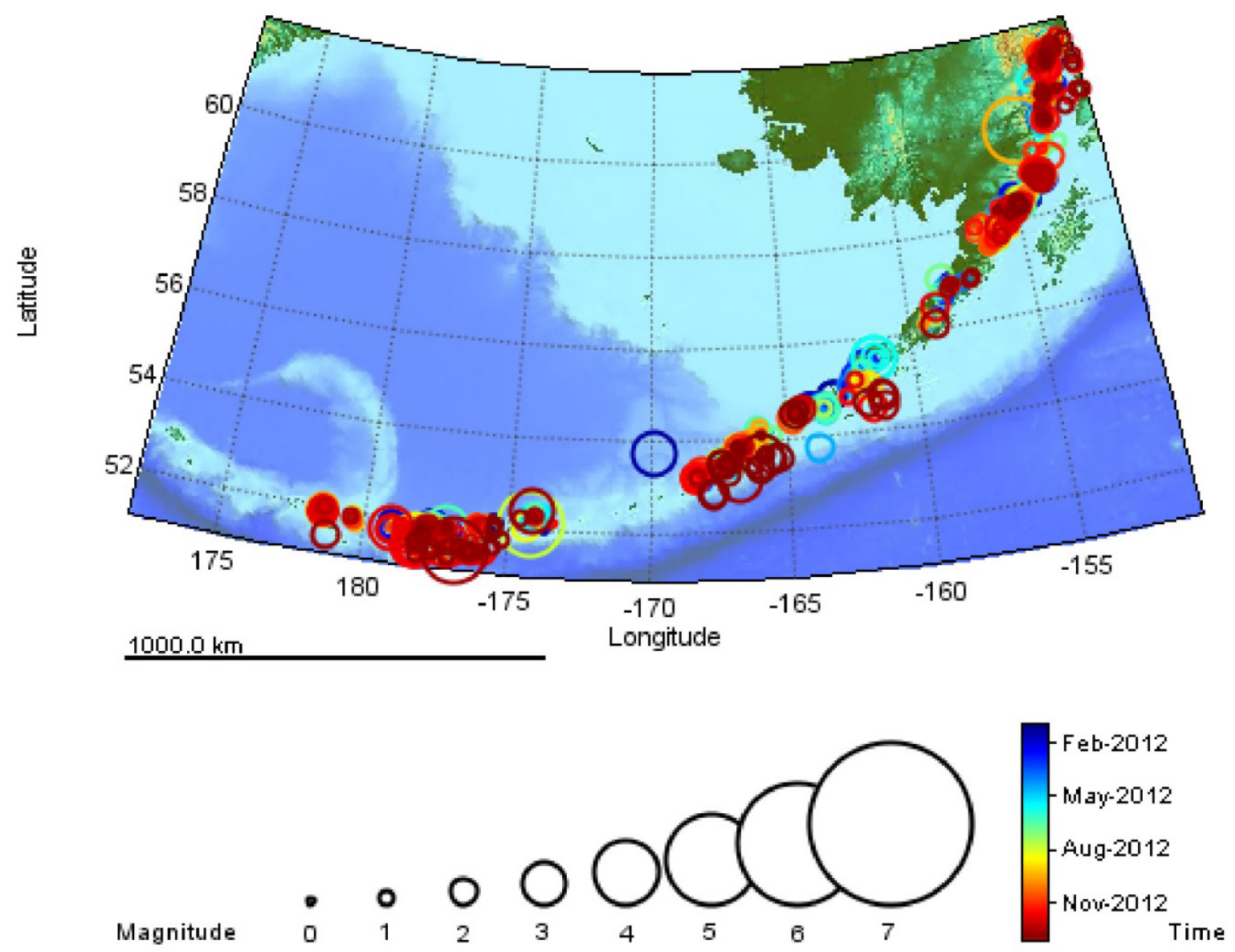

Figure A1. Map of the Aleutian arc and the earthquakes (open circles) located by AVO in 2012. Earthquakes are scaled by magnitude and the color of the symbols varies with date. 


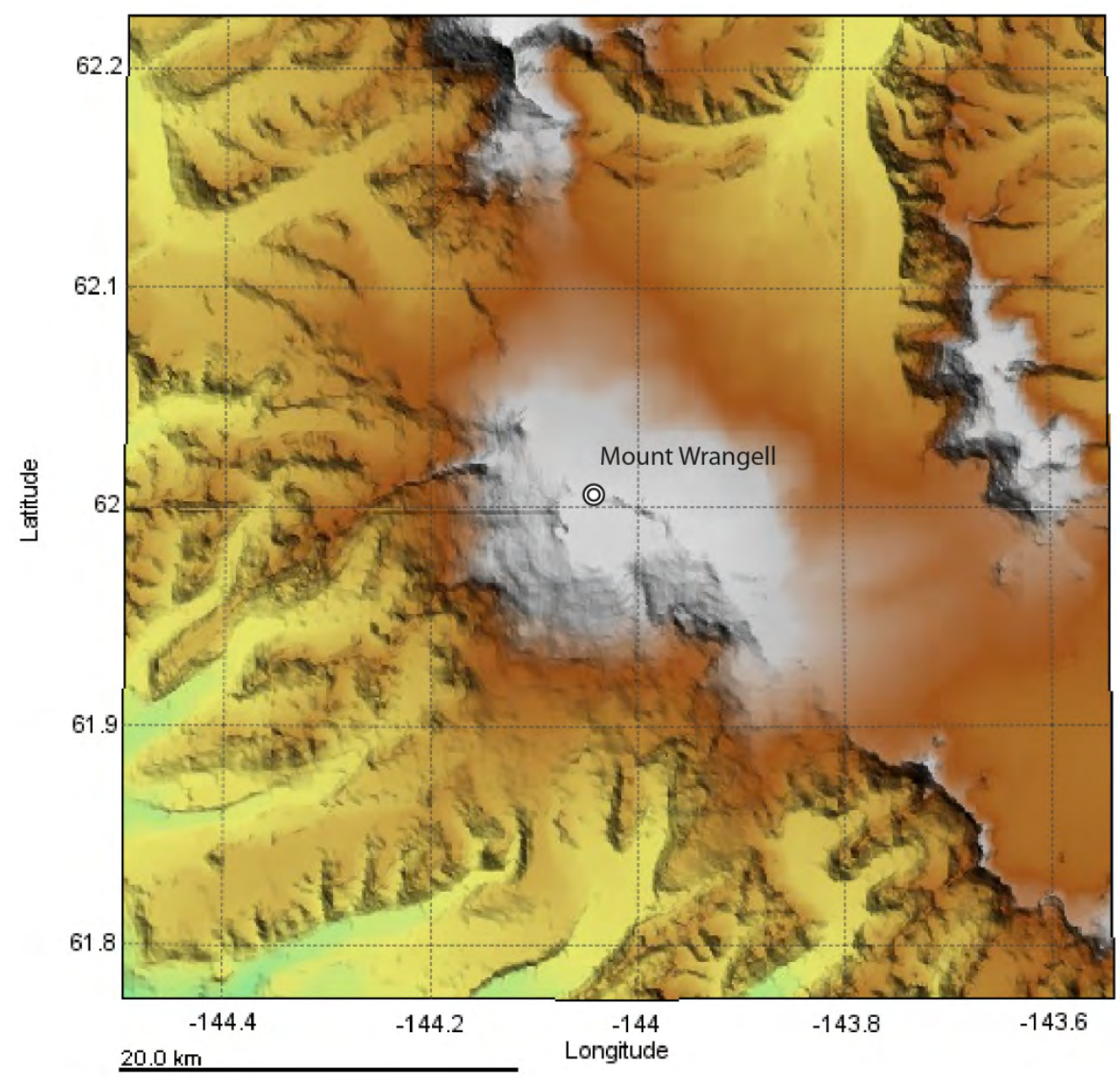

Figure A2. Summary plots of earthquakes located near Mount Wrangell in 2012. No earthquakes were located at Mount Wrangell in 2012. Volcanic centers are shown by black circles. 

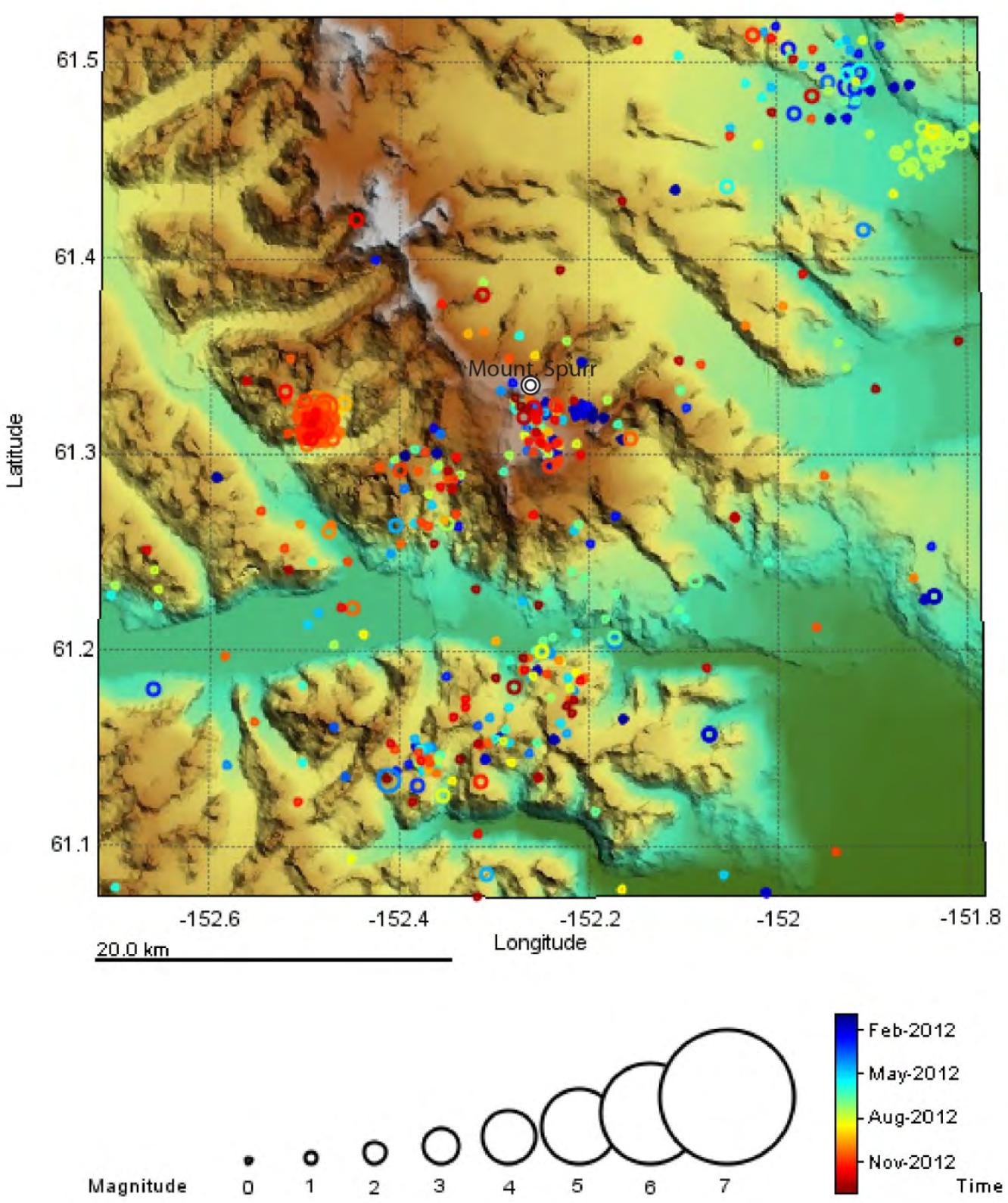

Figure A3. Summary plots of earthquakes located near Mount Spurr in 2012. Earthquakes are shown by open circles and are scaled by magnitude. Volcanic centers are shown by black circles. 


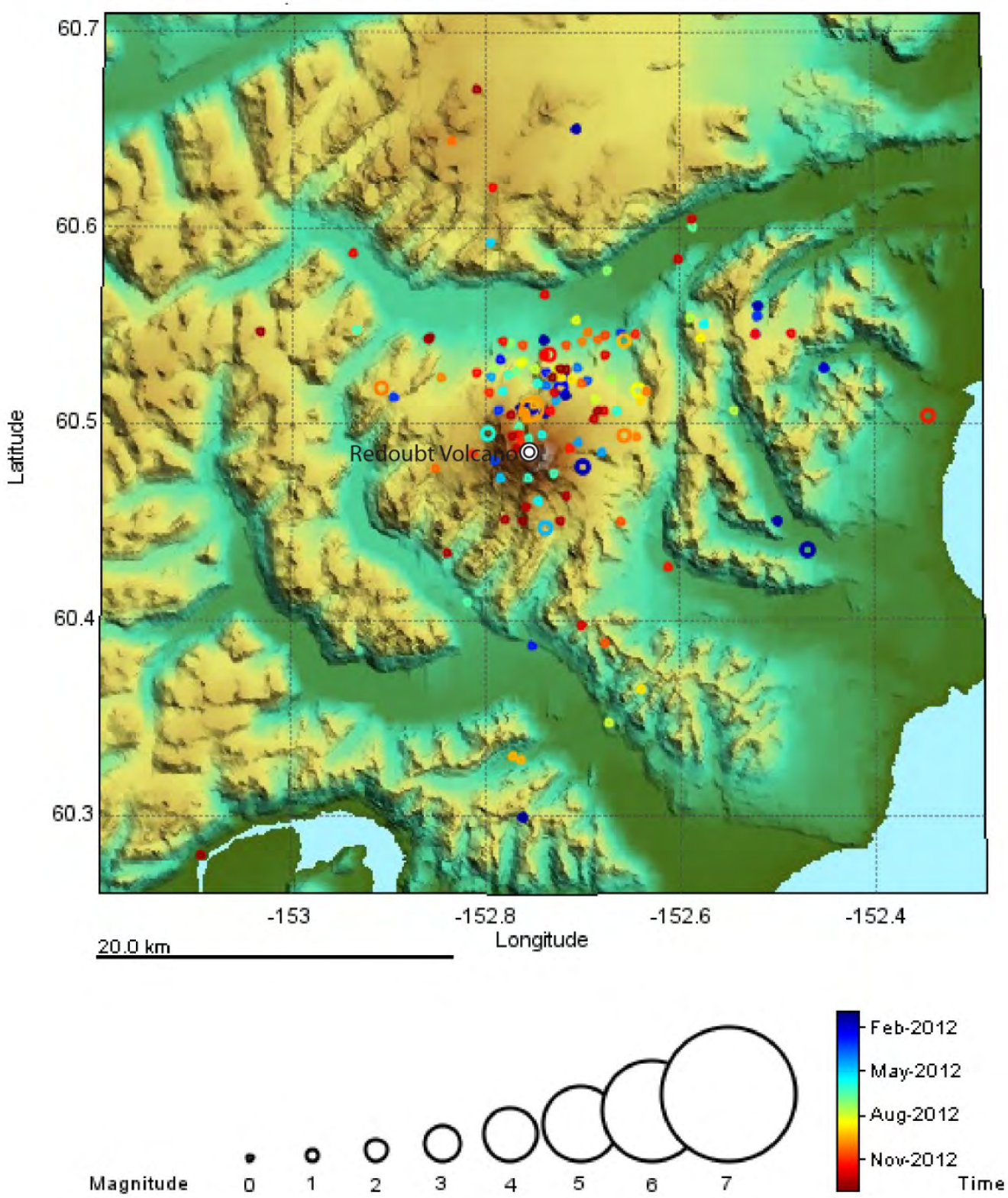

Figure A4. Summary plots of earthquakes located near Redoubt Volcano in 2012. Earthquakes are shown by open circles and are scaled by magnitude. Volcanic centers are shown by black circles. 

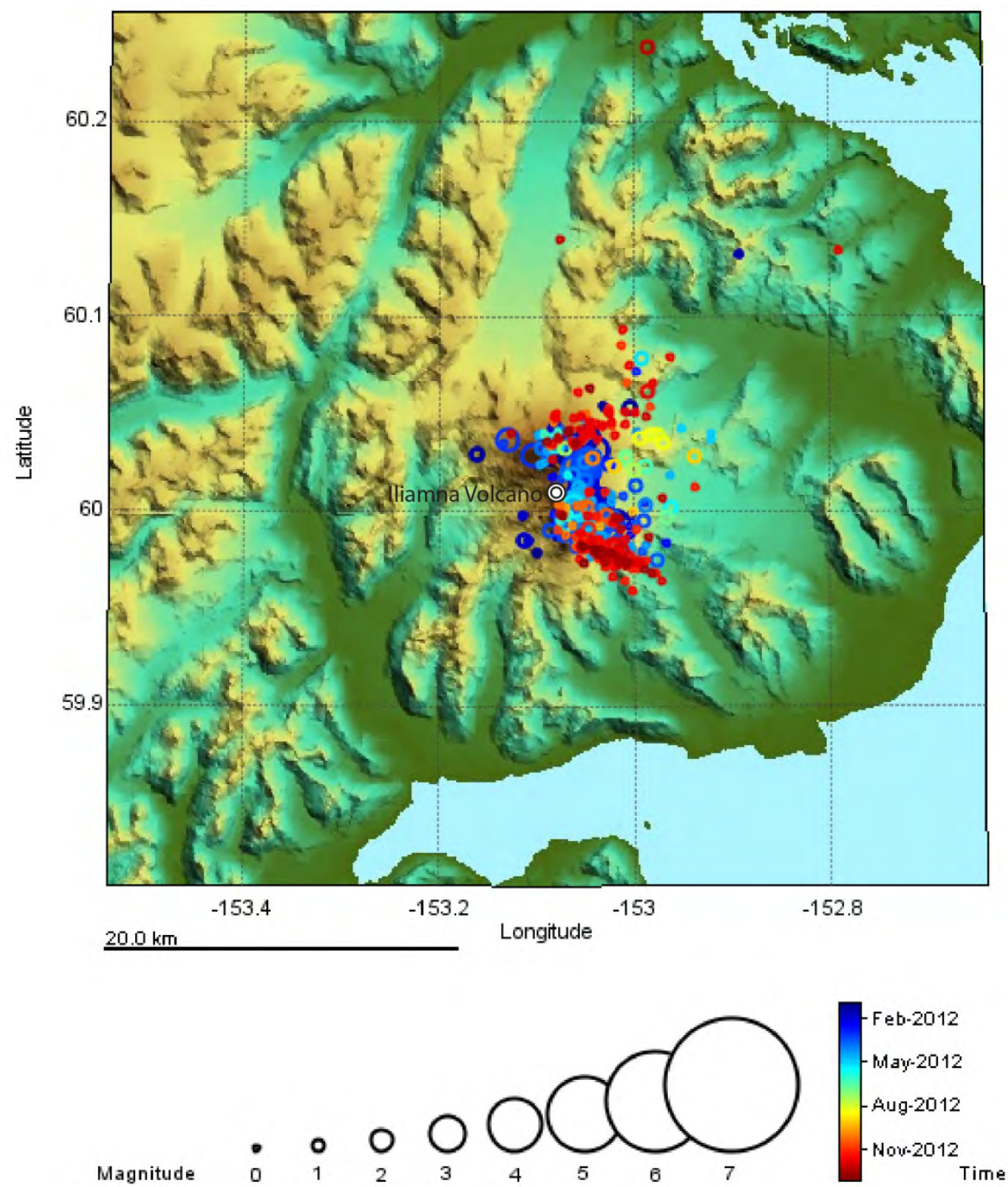

Figure A5. Summary plots of earthquakes located near lliamna Volcano in 2012. Earthquakes are shown by open circles and are scaled by magnitude. Volcanic centers are shown by black circles. 

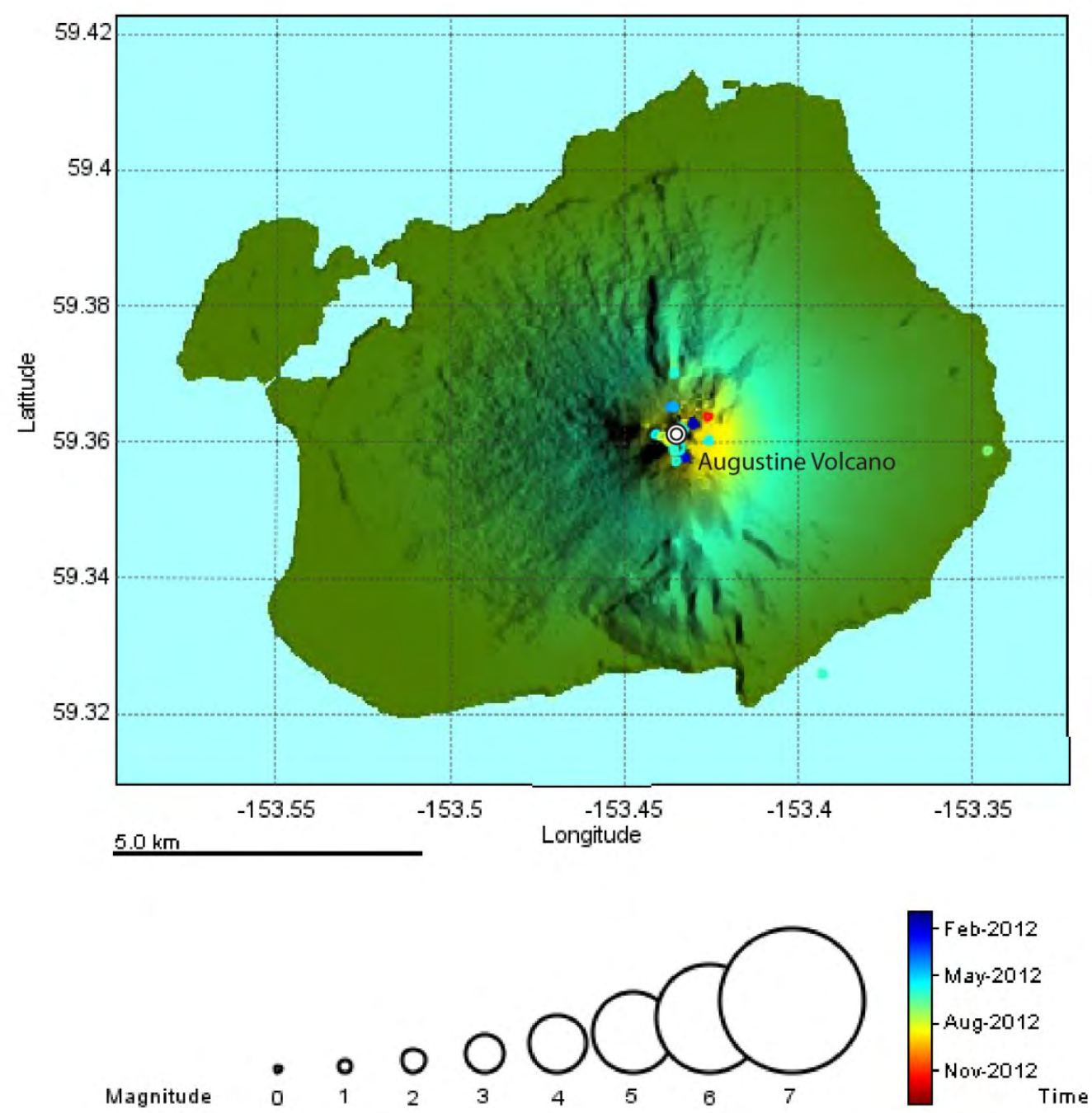

Figure A6. Summary plots of earthquakes located near Augustine Volcano in 2012. Earthquakes are shown by open circles and are scaled by magnitude. Volcanic centers are shown by black circles. 

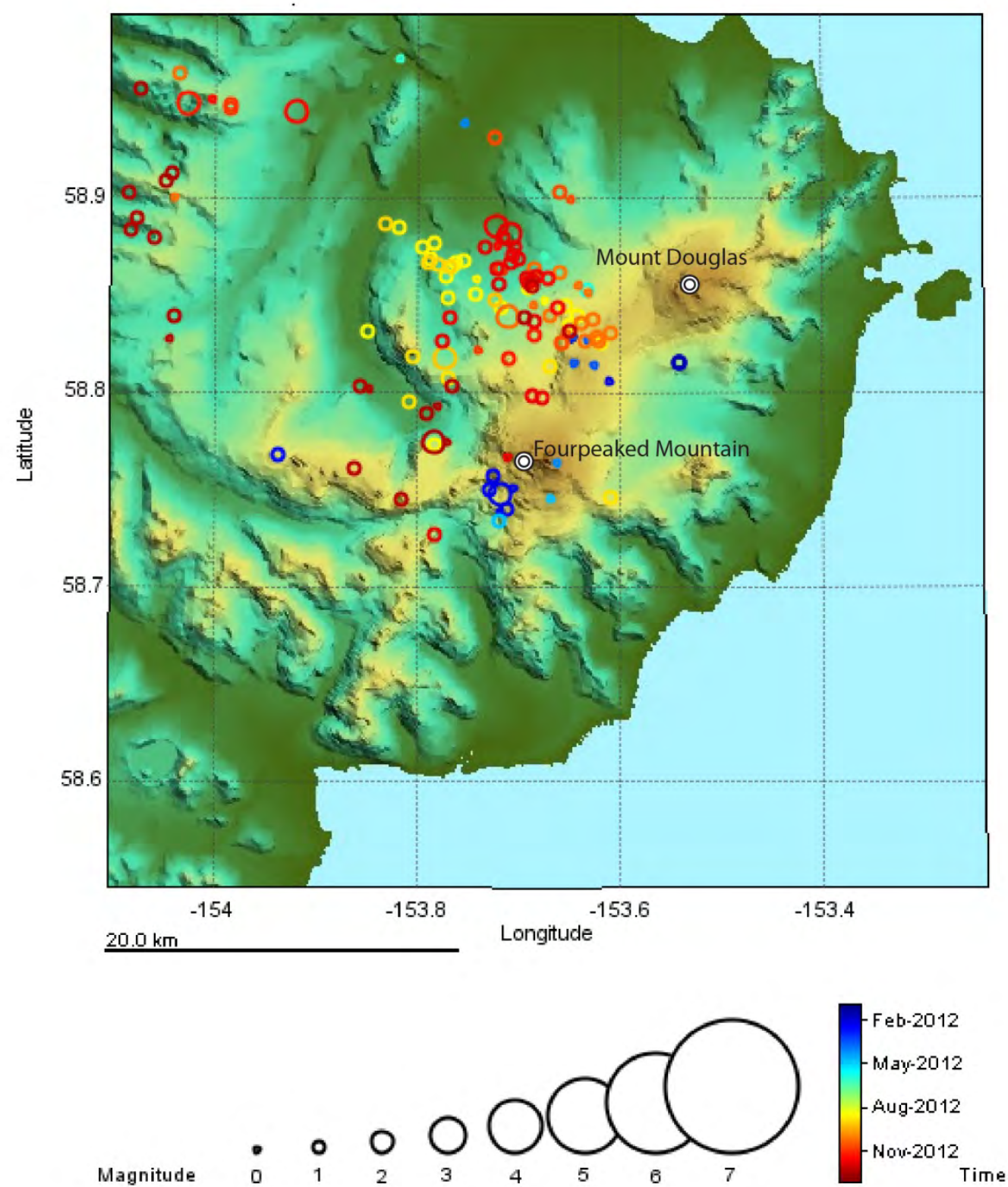

Figure A7. Summary plots of earthquakes located near Fourpeaked Mountain in 2012. Earthquakes are shown by open circles and are scaled by magnitude. Volcanic centers are shown by black circles. 

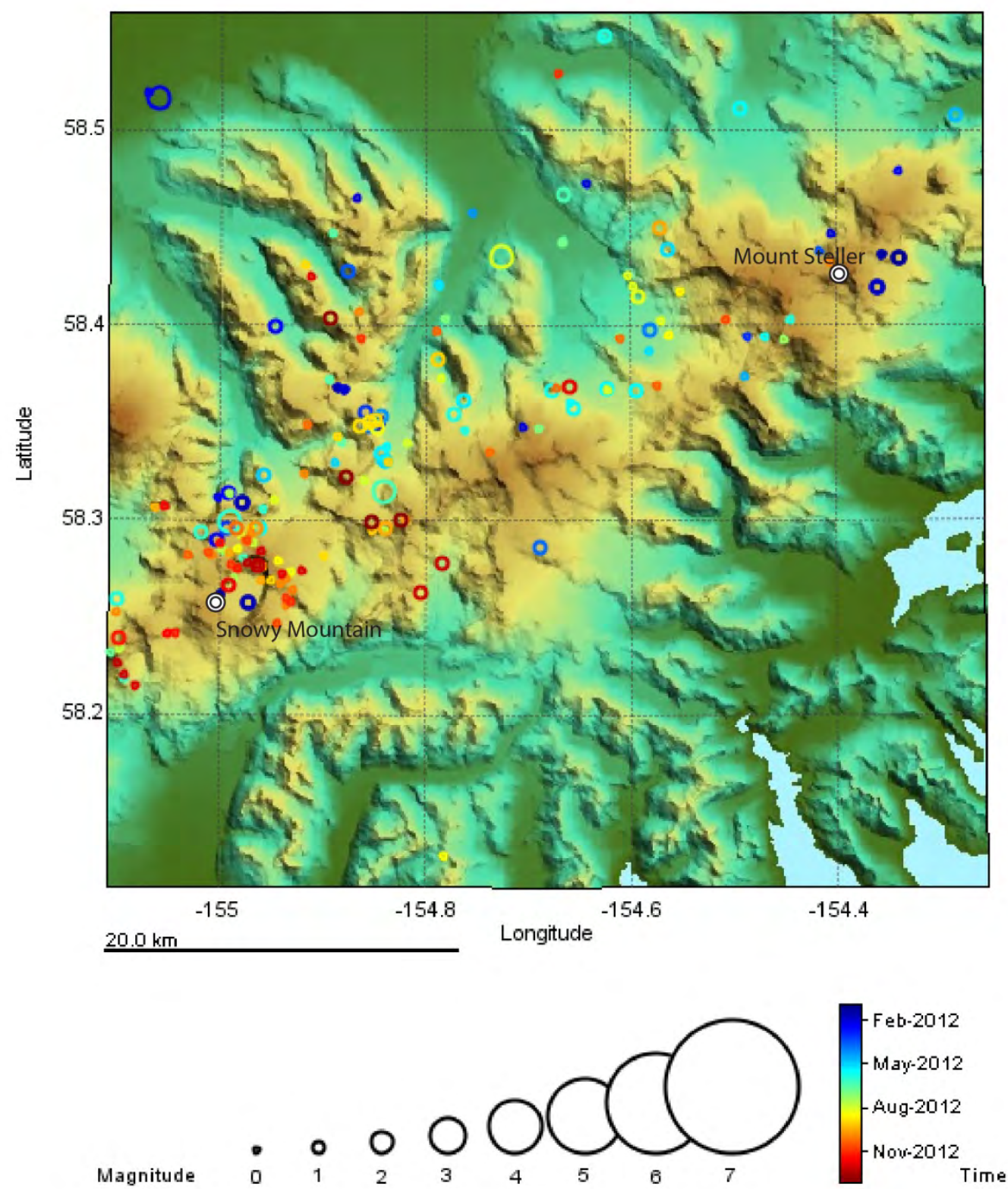

Figure A8. Summary plots of earthquakes located near Mount Steller and Snowy Mountain in 2012. Earthquakes are shown by open circles and are scaled by magnitude. Volcanic centers are shown by black circles. 

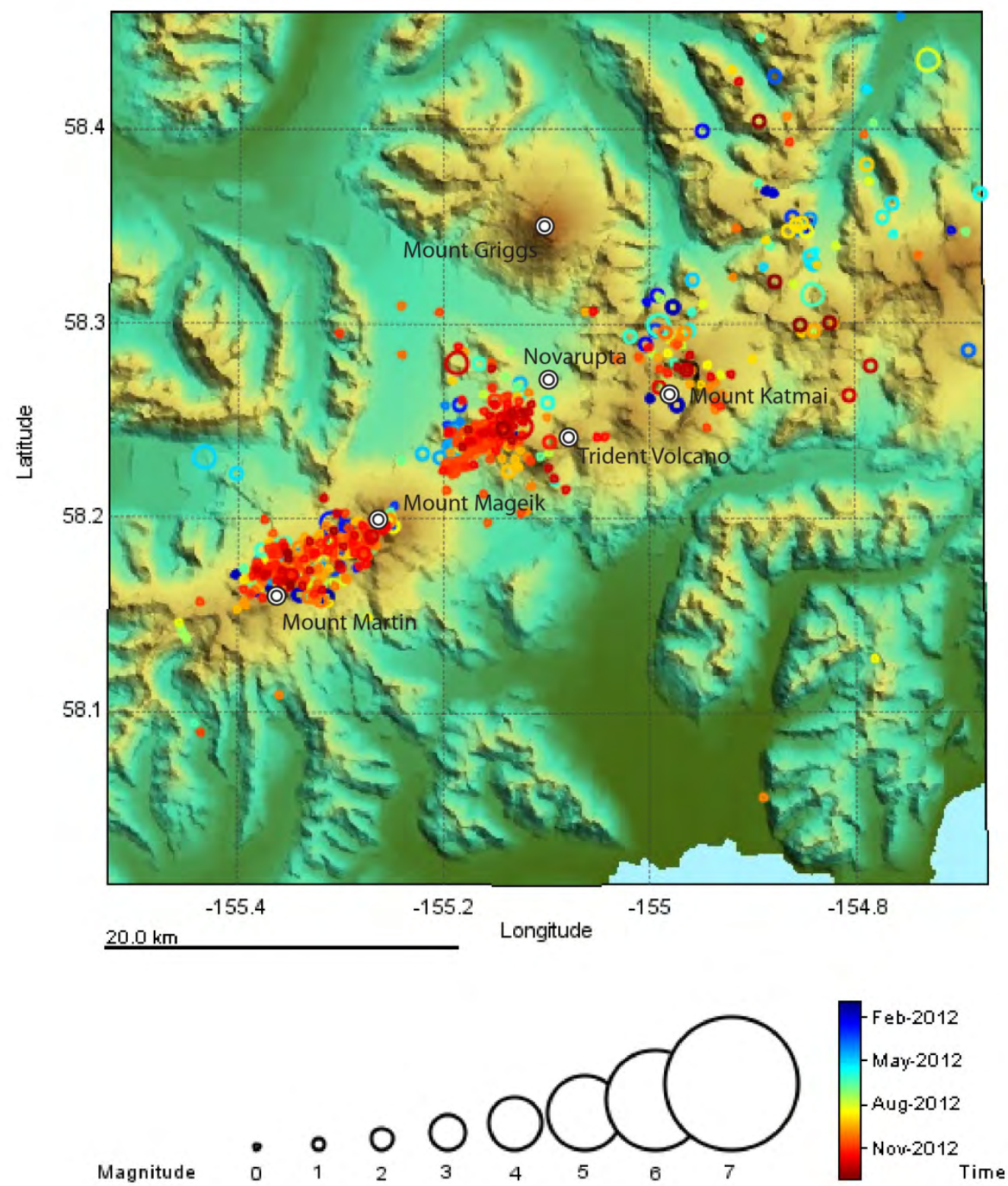

Figure A9. Summary plots of earthquakes located near Mount Griggs, Mount Katmai, Mount Martin, Mount Mageik, Novarupta, and Trident Volcano in 2012. Earthquakes are shown by open circles and are scaled by magnitude. Volcanic centers are shown by black circles. 


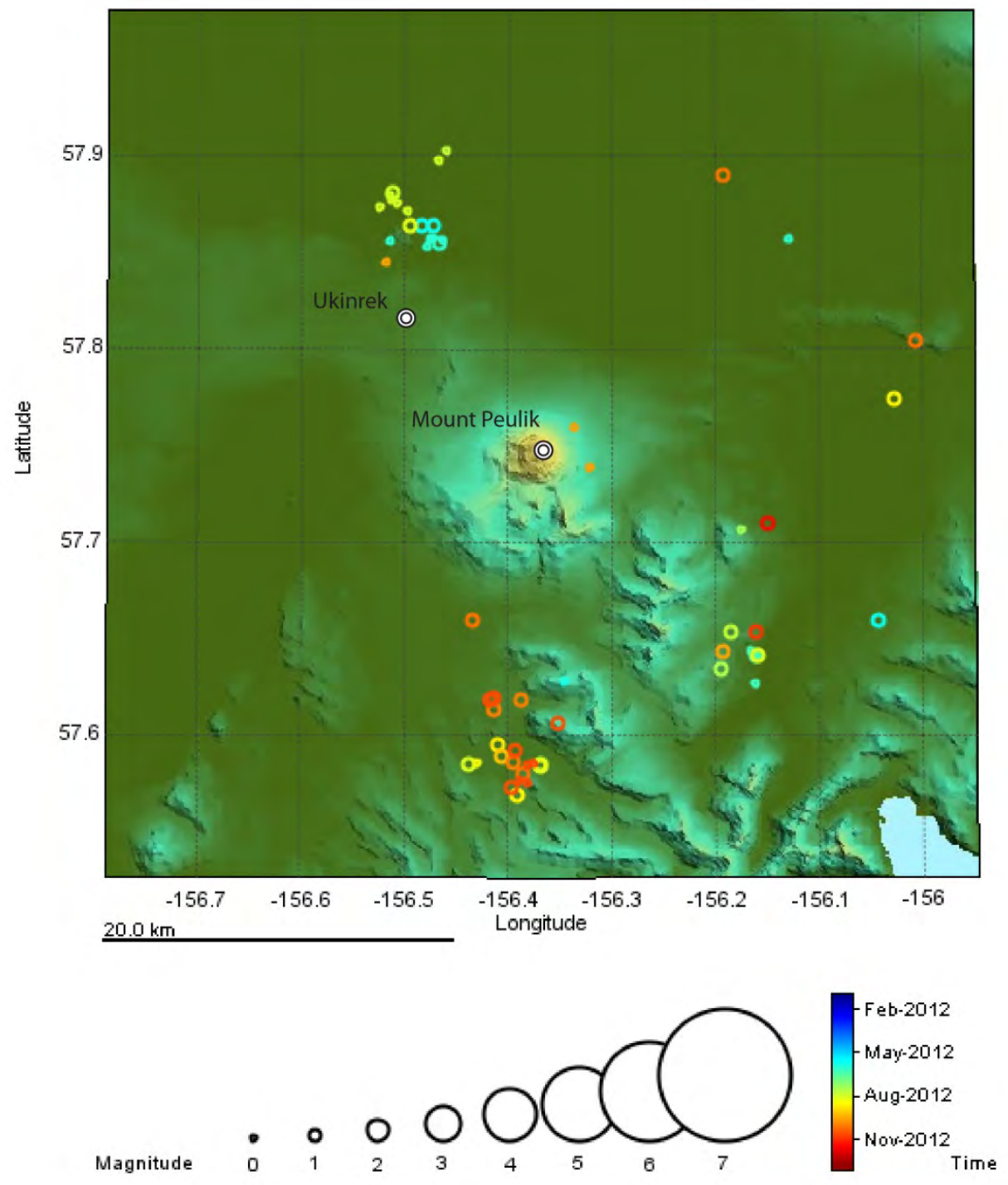

Figure A10. Summary plots of earthquakes located near Mount Peulik in 2012. Earthquakes are shown by open circles and are scaled by magnitude. Volcanic centers are shown by black circles. 


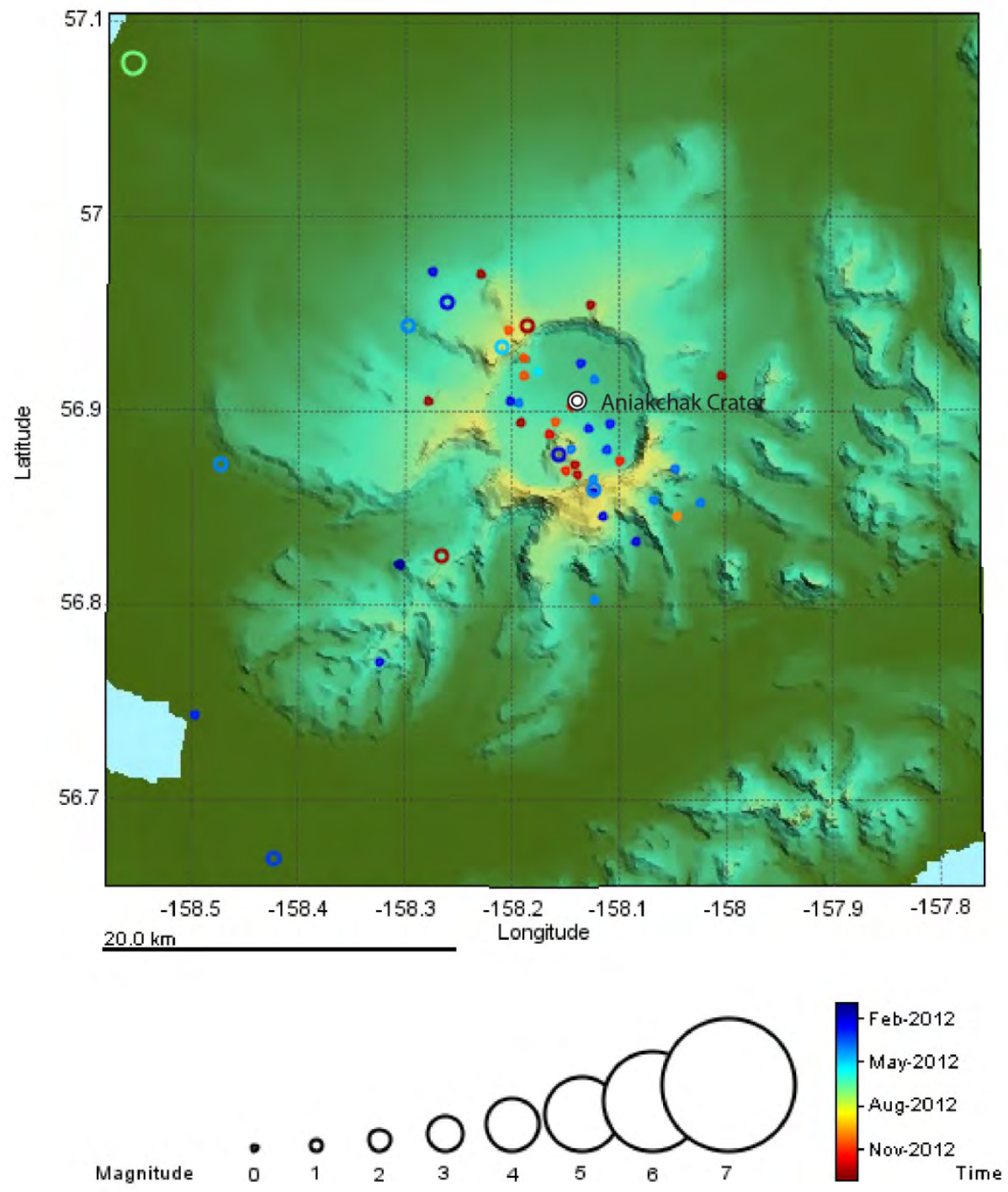

Figure A11. Summary plots of earthquakes located near Aniakchak Crater in 2012. Earthquakes are shown by open circles and are scaled by magnitude. Volcanic centers are shown by black circles. 


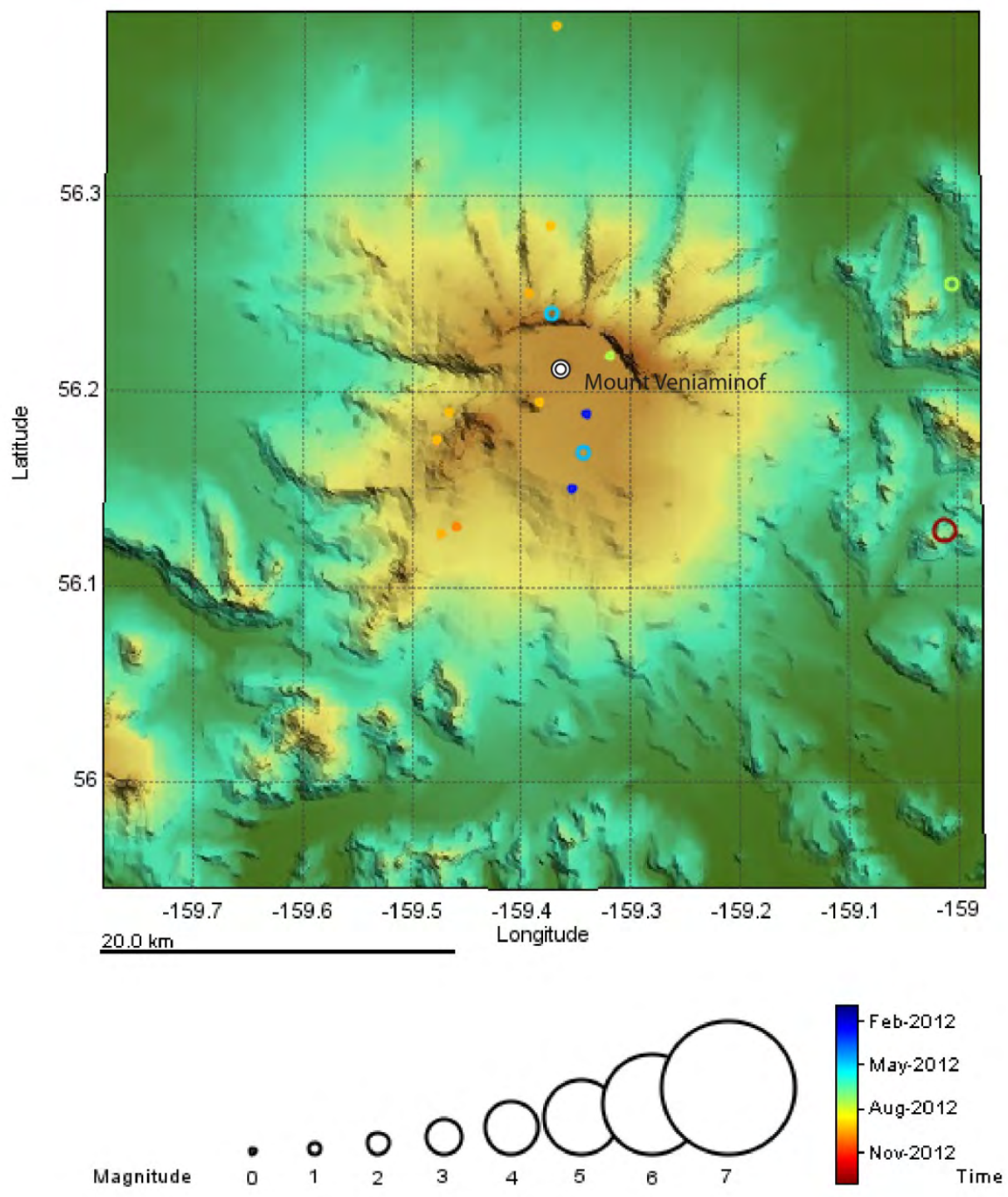

Figure A12. Summary plots of earthquakes located near Mount Veniaminof in 2012. Earthquakes are shown by open circles and are scaled by magnitude. Volcanic centers are shown by black circles. 


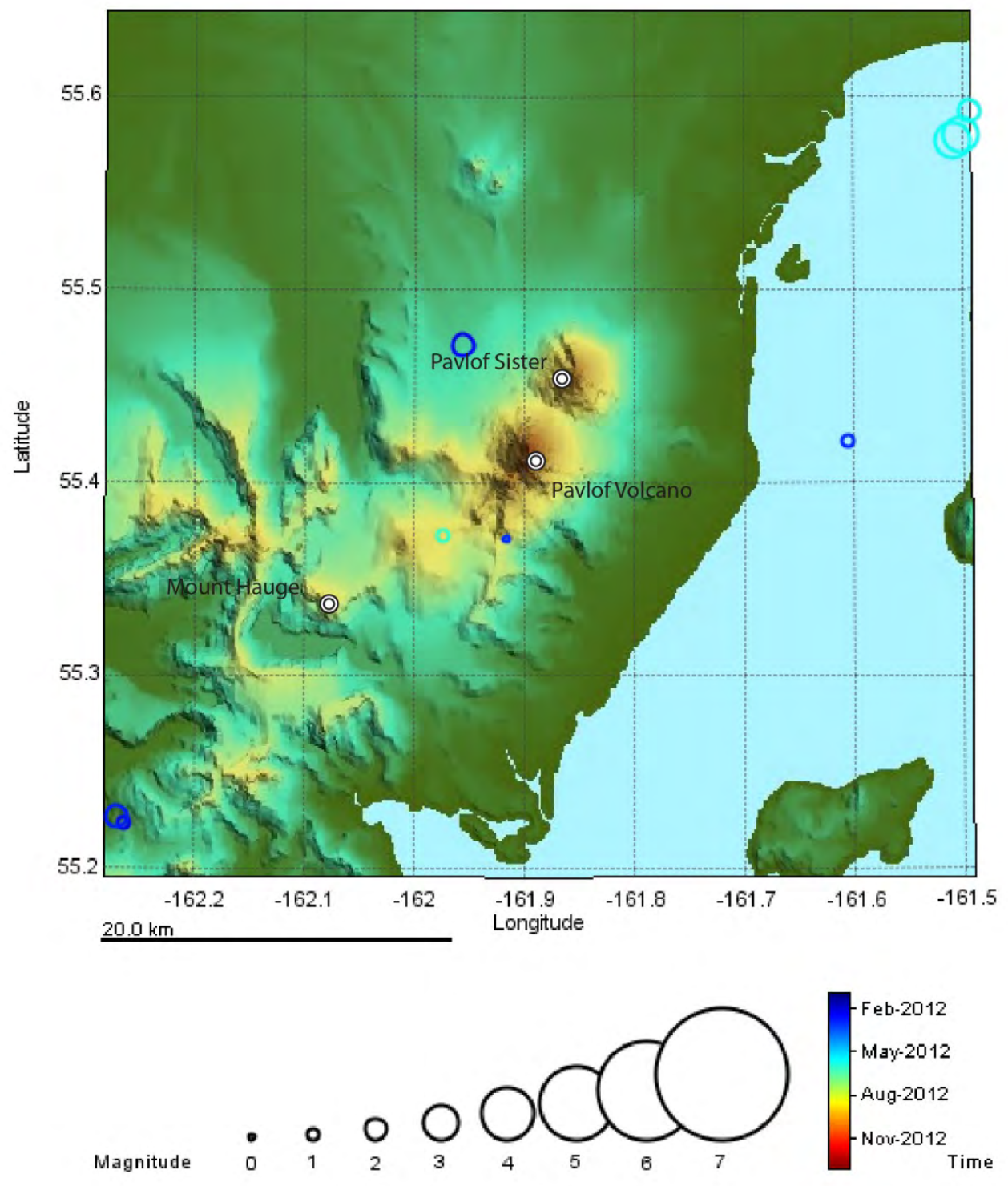

Figure A13. Summary plots of earthquakes located near Pavlof Volcano in 2012. Earthquakes are shown by open circles and are scaled by magnitude. Volcanic centers are shown by black circles. 


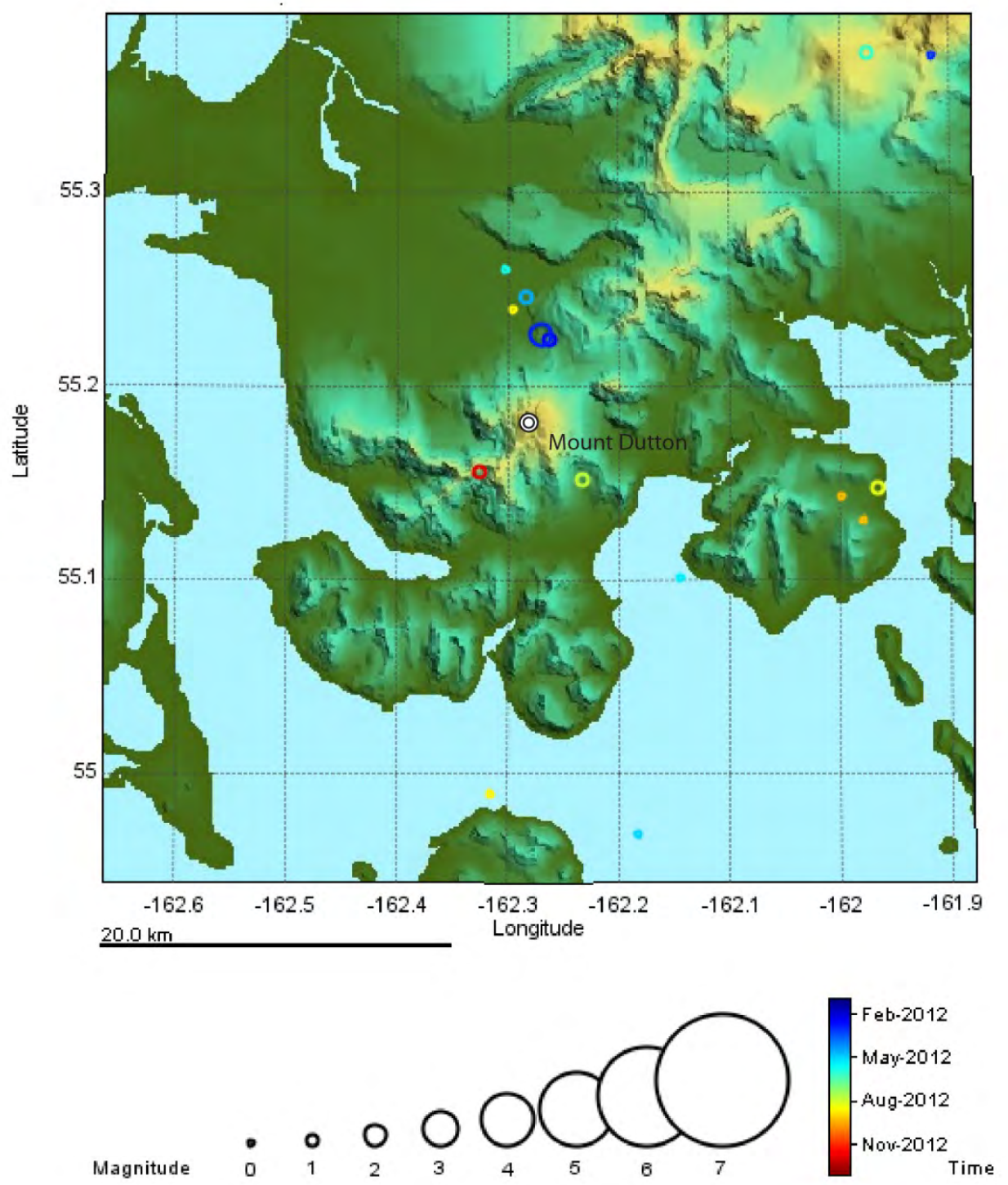

Figure A14. Summary plots of earthquakes located near Mount Dutton in 2012. Earthquakes are shown by open circles and are scaled by magnitude. Volcanic centers are shown by black circles. 


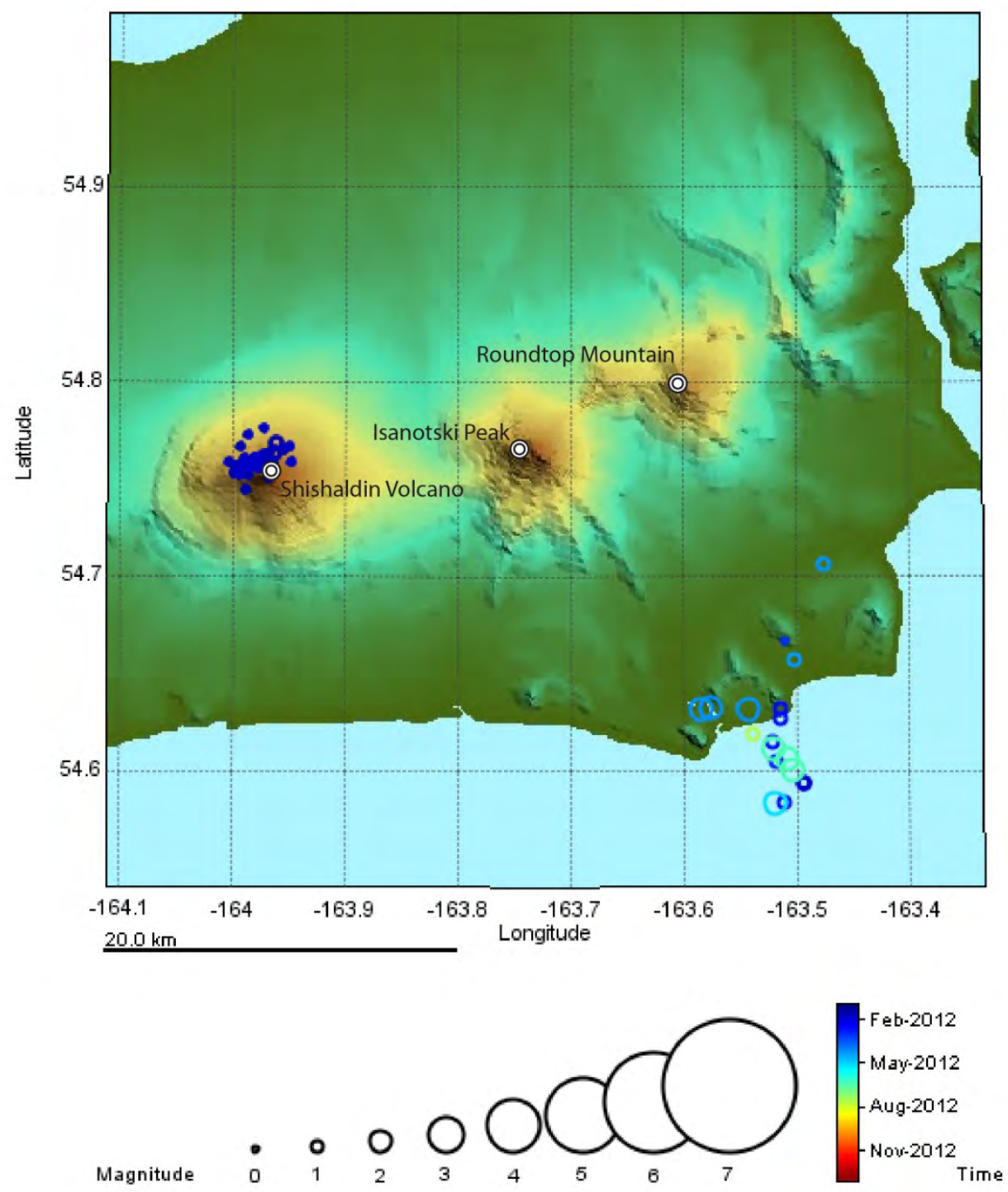

Figure A15. Summary plots of earthquakes located near Isanotski Peaks and Shishaldin Volcano in 2012.

Earthquakes are shown by open circles and are scaled by magnitude. Volcanic centers are shown by black circles. 

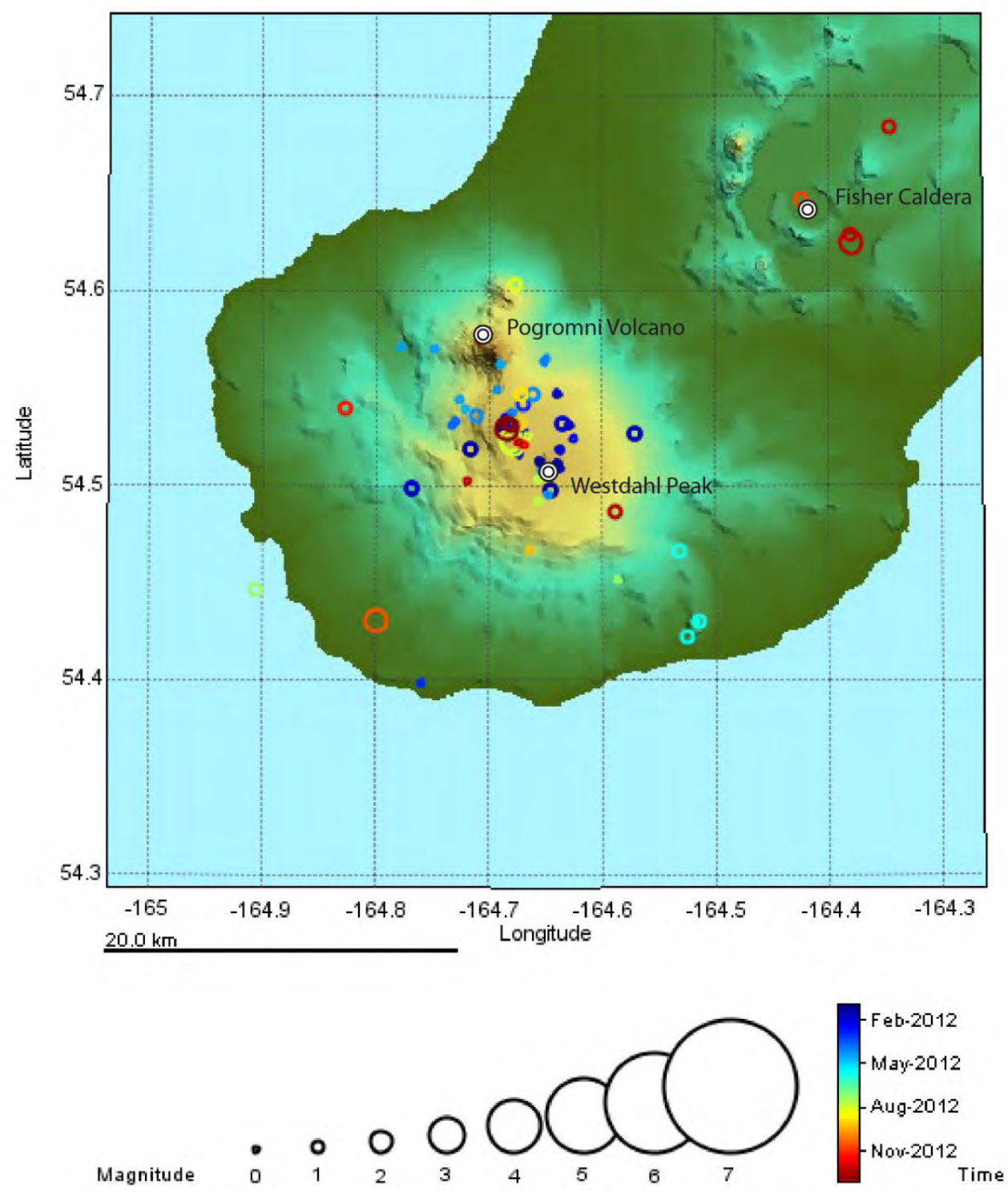

Figure A16. Summary plots of earthquakes located near Fisher Caldera and Westdahl Peak in 2012. Earthquakes are shown by open circles and are scaled by magnitude. Volcanic centers are shown by black circles. 


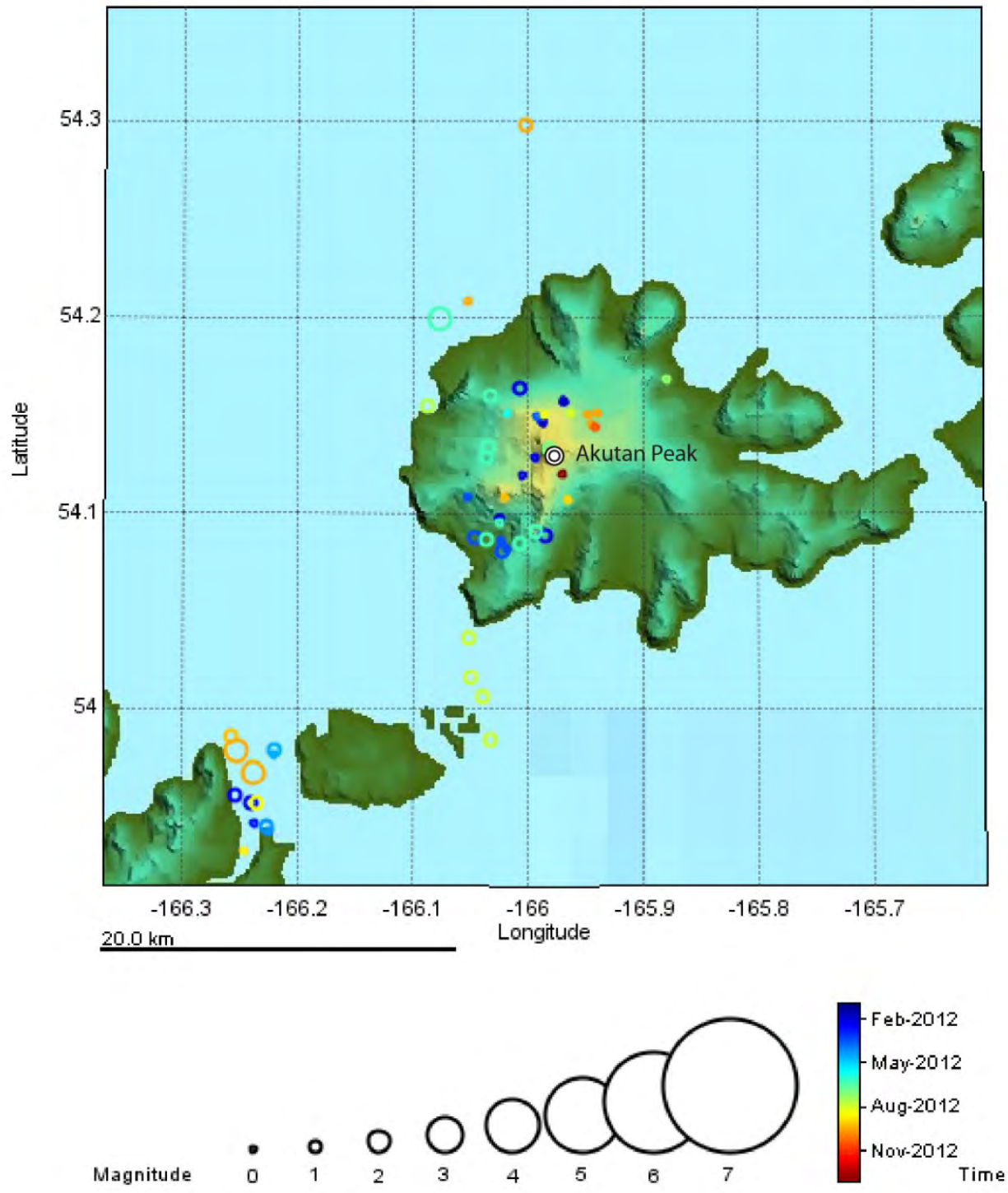

Figure A17. Summary plots of earthquakes located near Akutan Peak in 2012. Earthquakes are shown by open circles and are scaled by magnitude. Volcanic centers are shown by black circles. 

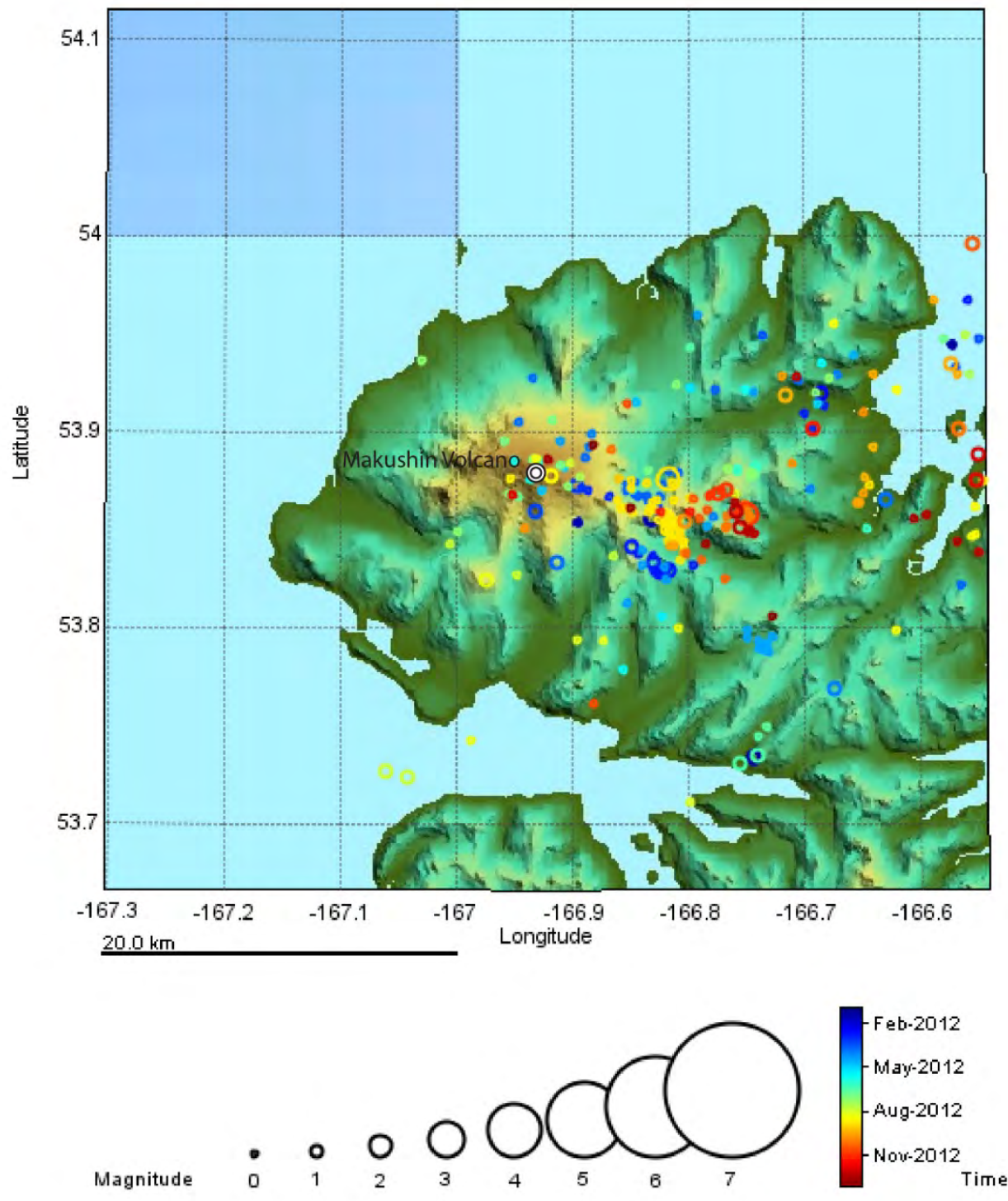

Figure A18. Summary plots of earthquakes located near Makushin Volcano in 2012. Earthquakes are shown by open circles and are scaled by magnitude. Volcanic centers are shown by black circles. 


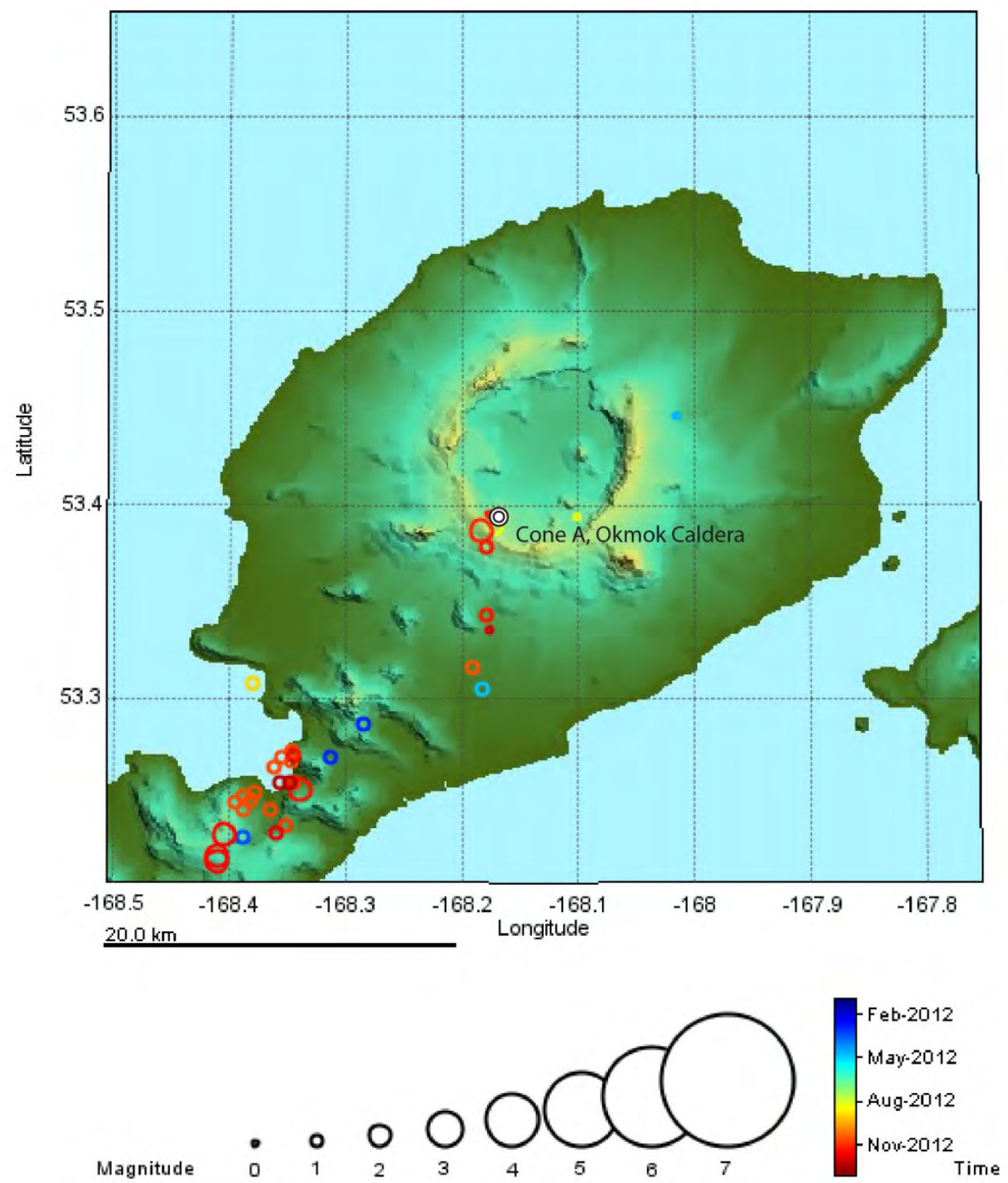

Figure A19. Summary plots of earthquakes located near Okmok Caldera in 2012. Earthquakes are shown by open circles and are scaled by magnitude. Volcanic centers are shown by black circles. 


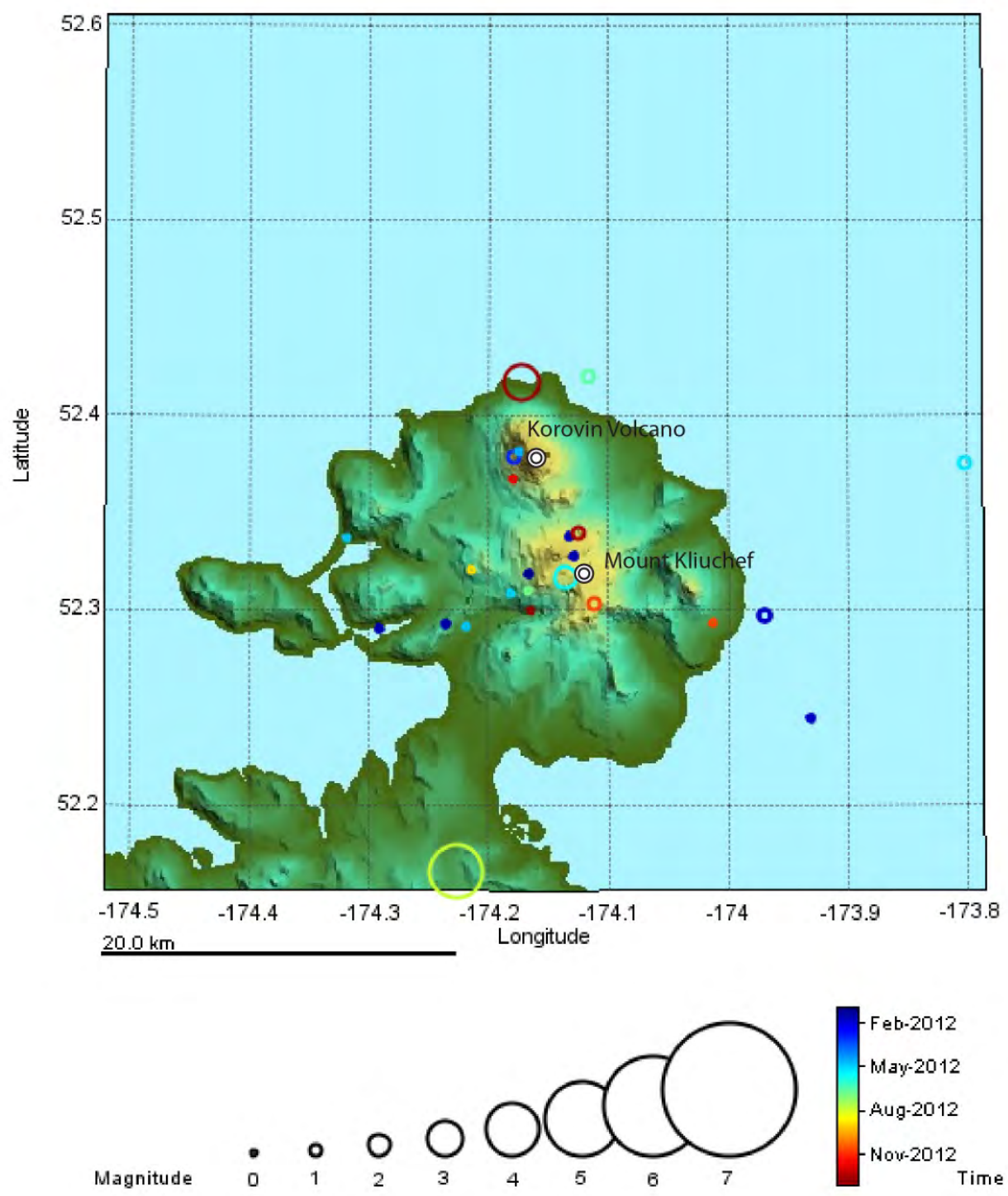

Figure A20. Summary plots of earthquakes located near Mount Kliuchef and Korovin Volcano in 2012. Earthquakes are shown by open circles and are scaled by magnitude. Volcanic centers are shown by black circles. 

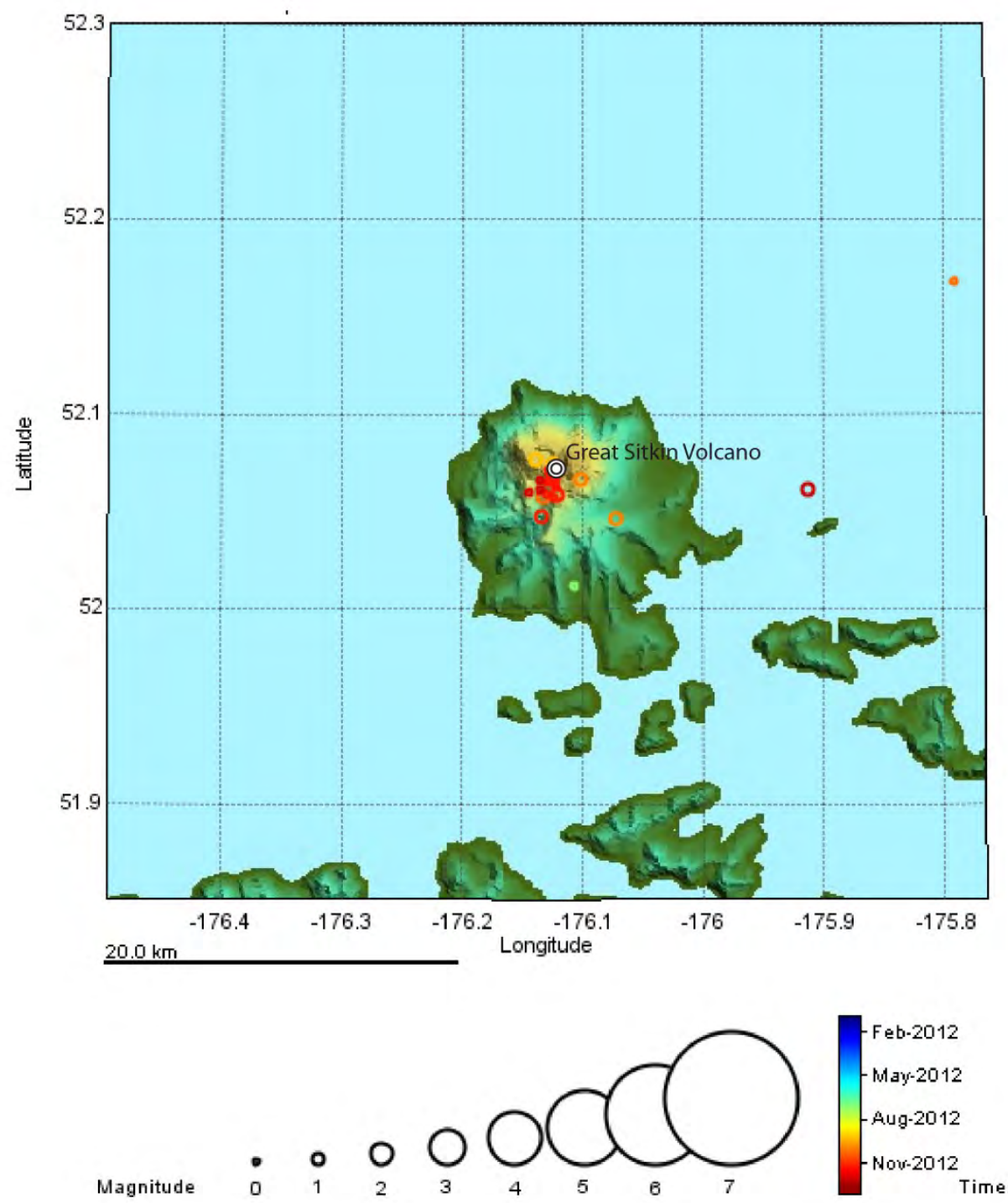

Figure A21. Summary plots of earthquakes located near Great Sitkin Volcano in 2012. Earthquakes are shown by open circles and are scaled by magnitude. Volcanic centers are shown by black circles. 


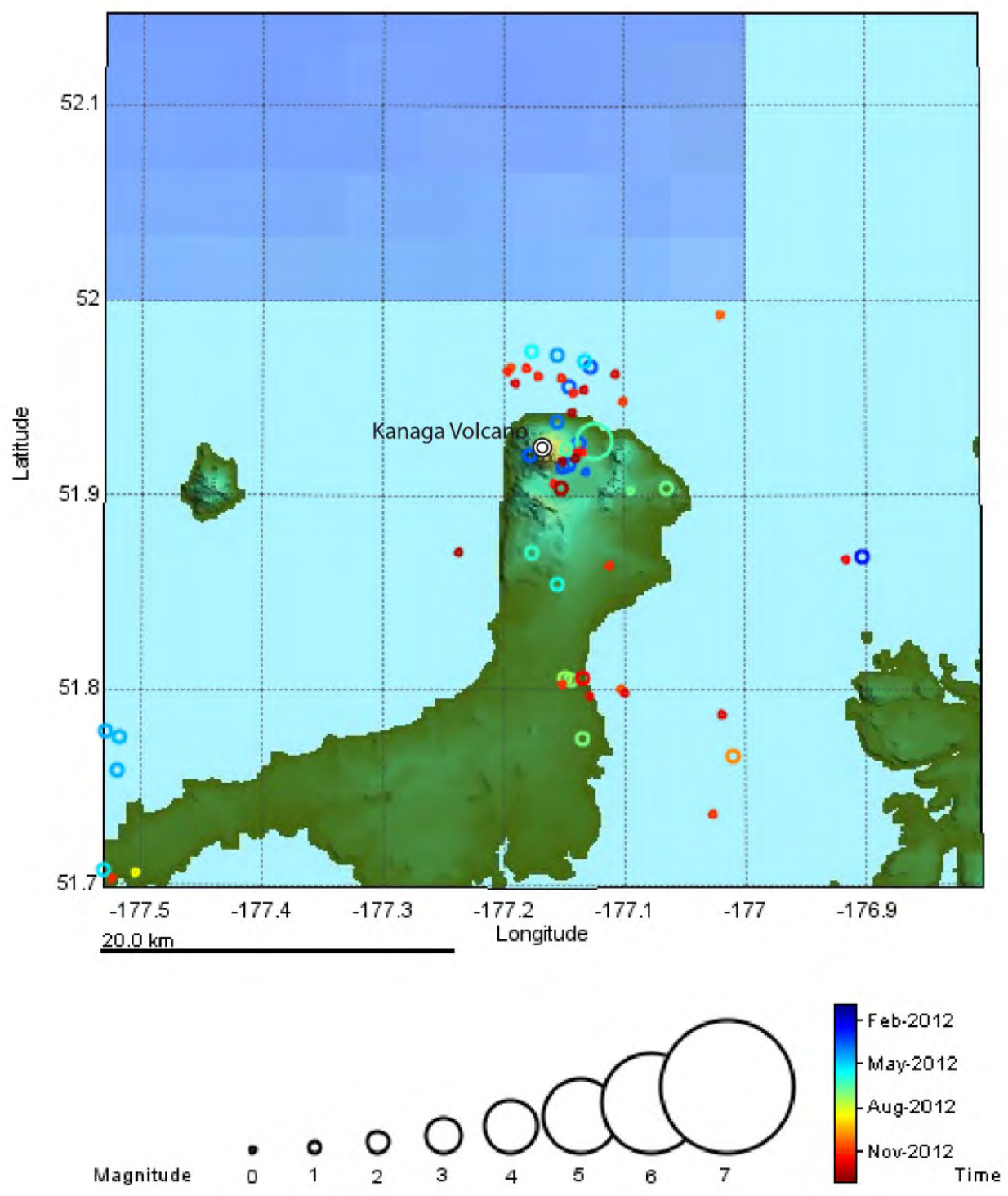

Figure A22. Summary plots of earthquakes located near Kanaga Volcano in 2012. Earthquakes are shown by open circles and are scaled by magnitude. Volcanic centers are shown by black circles. 


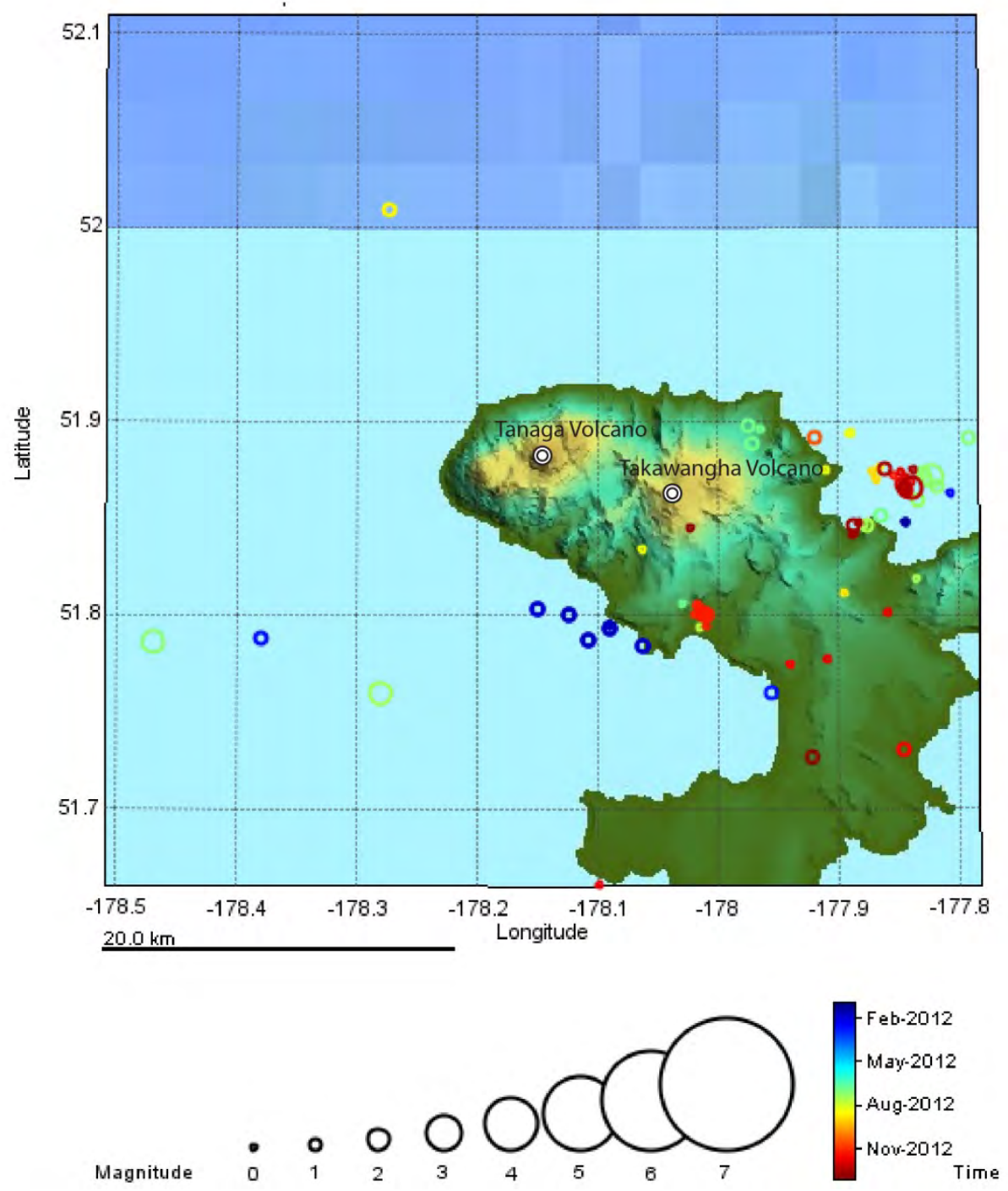

Figure A23. Summary plots of earthquakes located near Tanaga Volcano and Takawangha Volcano in 2012. Earthquakes are shown by open circles and are scaled by magnitude. Volcanic centers are shown by black circles. 

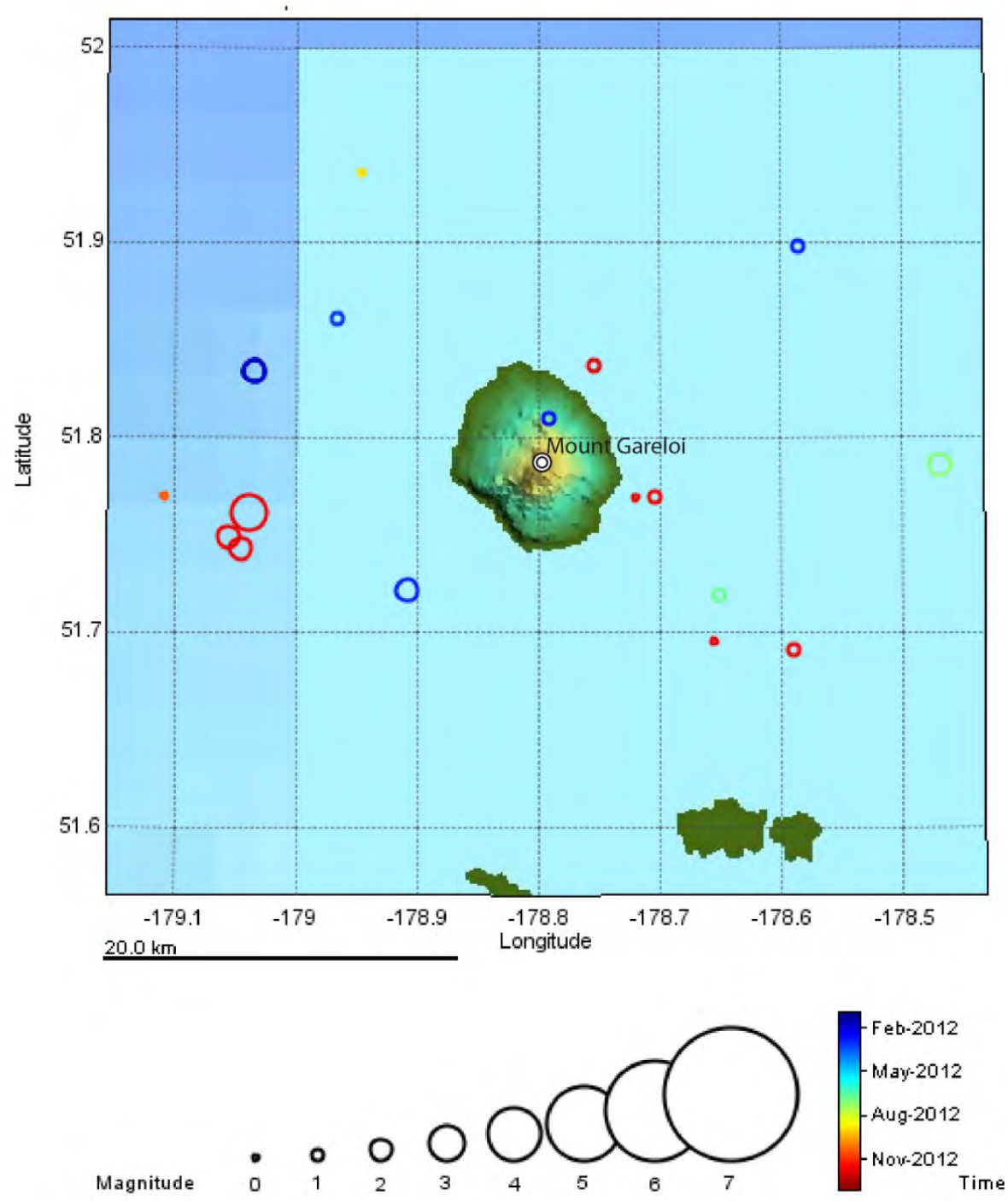

Figure A24. Summary plots of earthquakes located near Mount Gareloi in 2012. Earthquakes are shown by open circles and are scaled by magnitude. Volcanic centers are shown by black circles. 

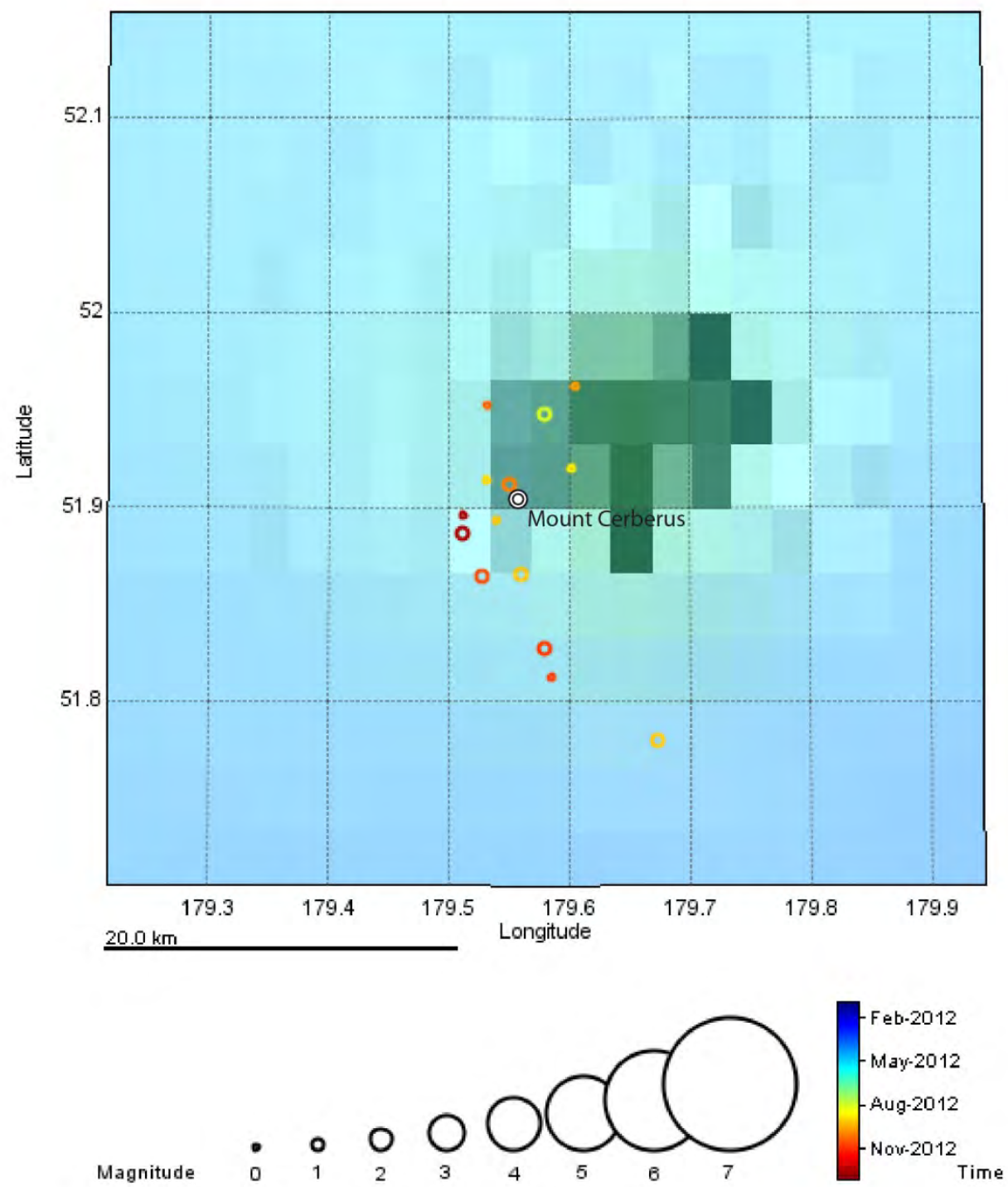

Figure A25. Summary plots of earthquakes located near Mount Cerberus in 2012. Earthquakes are shown by open circles and are scaled by magnitude. Volcanic centers are shown by black circles. 

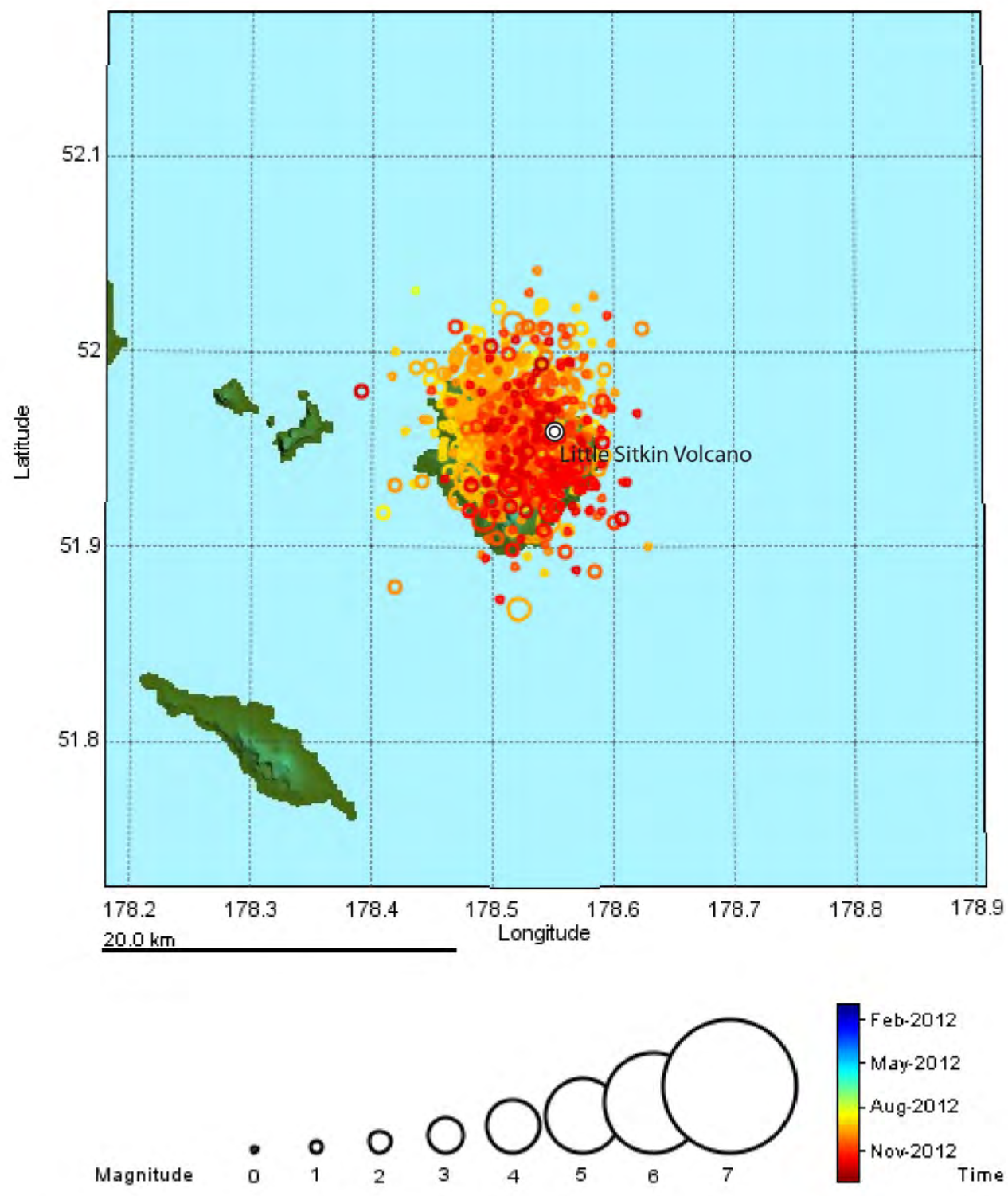

Figure A26. Summary plots of earthquakes located near Little Sitkin Volcano in 2012. Earthquakes are shown by open circles and are scaled by magnitude. Volcanic centers are shown by black circles. 


\section{Appendix B. Parameters for AVO Seismograph Stations (datum WGS84) in 2012.}

This list includes station parameters for seismograph stations operated by the Alaska Volcano Observatory (AVO), Alaska Earthquake Information Center (AEIC) and the West Coast-Alaska Tsunami Warning Center (WC-ATWC) that were used to locate earthquakes in the AVO catalog. The open date is the date that data were first recorded and the close date is the date that recording was stopped. Discounting temporary data outages, data are available for each listed station between the open and close date. Stations still in operation are indicated by a dash in the close date column.

\begin{tabular}{|c|c|c|c|c|c|c|}
\hline \multicolumn{7}{|c|}{ Akutan Peak subnet } \\
\hline$\underline{\text { Station }}$ & Latitude (N) & Longitude (E) & Elevation (m) & $\underline{\text { Seismometer }}$ & Open date & Close date \\
\hline$\overline{\mathrm{AHB}}$ & 54.1144 & -165.8177 & 447 & $\overline{\mathrm{L} 4}$ & $\overline{1996 / 07 / 24}$ & - \\
\hline $\mathrm{AKBB}^{\mathrm{B}}$ & 54.0975 & -165.9338 & 310 & CMG-6TD & $2005 / 07 / 05$ & - \\
\hline $\mathrm{AKGG}^{\mathrm{B}}$ & 54.1979 & -165.9936 & 326 & CMG-6TD & $2003 / 06 / 27$ & - \\
\hline $\mathrm{AKLV}^{\mathrm{B}}$ & 54.1618 & -16.9576 & 551 & CMG-6TD & $2003 / 07 / 02$ & - \\
\hline $\mathrm{AKMO}^{\mathrm{B}}$ & 54.0903 & -166.0126 & 277 & CMG-6TD & $2003 / 06 / 25$ & - \\
\hline $\mathrm{AKRB}^{\mathrm{B}}$ & 54.1292 & -166.0708 & 334 & CMG-6TD & $2003 / 06 / 29$ & - \\
\hline $\mathrm{AKS}^{3 \mathrm{P}}$ & 54.1095 & -165.6987 & 213 & $\mathrm{~L} 22$ & $1996 / 07 / 24$ & - \\
\hline $\mathrm{AKSA}^{\mathrm{B}}$ & 54.1095 & -165.6987 & 213 & CMG-6TD & 2011/07/14 & - \\
\hline $\mathrm{AKT}^{\mathrm{B}}$ & 54.1349 & -165.7720 & 12 & CMG-40T & $1996 / 03 / 18$ & - \\
\hline $\mathrm{AKV}$ & 54.1253 & -165.9647 & 863 & L4 & $1996 / 07 / 24$ & - \\
\hline HSB & 54.1859 & -165.9144 & 497 & L4 & $1996 / 07 / 24$ & - \\
\hline LVA & 54.1600 & -166.0358 & 457 & L4 & $1996 / 07 / 24$ & - \\
\hline ZRO & 54.0907 & -165.9800 & 446 & L4 & $1996 / 07 / 24$ & - \\
\hline \multicolumn{7}{|c|}{ Aniakchak Crater subnet } \\
\hline Station & Latitude (N) & Longitude (E) & Elevation (m) & $\underline{\text { Seismometer }}$ & Open date & Close date \\
\hline$\overline{\mathrm{ANNE}}$ & 56.9119 & -158.0610 & 705 & $\overline{\mathrm{L} 4}$ & $\overline{1997 / 07 / 18}$ & - \\
\hline ANNW & 56.9656 & -158.2170 & 816 & L4 & $1997 / 07 / 18$ & - \\
\hline $\mathrm{ANON}^{3}$ & 56.9190 & -158.1737 & 445 & L22 & 2000/07/09 & - \\
\hline ANPB & 56.8016 & -158.2829 & 658 & L4 & $1997 / 07 / 18$ & - \\
\hline ANPK & 56.8409 & -158.1283 & 972 & L4 & $1997 / 07 / 18$ & - \\
\hline AZAC & 56.8947 & -158.2328 & 1,057 & L4 & 2003/07/12 & - \\
\hline \multicolumn{7}{|c|}{ Augustine Volcano subnet } \\
\hline Station & Latitude (N) & Longitude (E) & Elevation (m) & $\underline{\text { Seismometer }}$ & Open date & Close date \\
\hline $\mathrm{AU} 22^{\mathrm{S}}$ & 59.3702 & -153.3573 & 105 & $130-\mathrm{ANSS} / 02$ & $2007 / 09 / 01$ & - \\
\hline AUE* $*^{P}$ & 59.3711 & -153.3773 & 168 & S13 & $1980 / 10 / 29$ & - \\
\hline AUH & 59.3632 & -153.4454 & 890 & S13 & 1978/12/01 & - \\
\hline $\mathrm{AUI}^{3}$ & 59.3345 & -153.4299 & 293 & $\mathrm{~S} 13$ & $1978 / 04 / 06$ & - \\
\hline AUJK & 59.3493 & -153.4106 & 377 & L4 & 2011/08/16 & - \\
\hline AUL & 59.3816 & -153.4379 & 360 & S13 & $1980 / 10 / 29$ & - \\
\hline $\mathrm{AUL}^{\mathrm{B}}$ & 59.3816 & -153.4379 & 360 & CMG-6TD & $1997 / 08 / 27$ & - \\
\hline AUNW* & 59.3775 & -153.4790 & 160 & L4 & 2006/03/15 & - \\
\hline AUP & 59.3627 & -153.4226 & 1,033 & L4 & $1977 / 09 / 22$ & - \\
\hline AUW & 59.3694 & -153.4730 & 276 & S13 & 1976/10/17 & - \\
\hline \multicolumn{7}{|c|}{ Mount Cerberus Subnet } \\
\hline Station & Latitude (N) & Longitude (E) & Elevation (m) & $\underline{\text { Seismometer }}$ & Open date & Close date \\
\hline CEAP & 52.0012 & 179.5758 & 244 & L4 & $2005 / 09 / 17$ & - \\
\hline CEPE & 51.9646 & 179.6472 & 335 & L4 & 2005/09/17 & - \\
\hline CERA & 51.9058 & 179.6826 & 305 & L4 & $2005 / 09 / 26$ & - \\
\hline $\mathrm{CERB}^{3}$ & 51.9302 & 179.6277 & 305 & L4-3D & $2005 / 09 / 18$ & - \\
\hline CESW & 51.8998 & 179.5613 & 238 & L4 & 2005/09/18 & - \\
\hline CETU & 51.9649 & 179.4922 & 335 & L4 & 2005/09/22 & - \\
\hline
\end{tabular}


Dutton subnet

\begin{tabular}{|c|c|c|c|c|c|c|}
\hline Station & Latitude (N) & Longitude (E) & Elevation (m) & $\underline{\text { Seismometer }}$ & Open date & Close date \\
\hline$\overline{\text { BLDY }}$ & 55.1936 & -162.7856 & 259 & $\overline{\mathrm{L} 4}$ & $\overline{1996 / 07 / 11}$ & - \\
\hline DOL & 55.1488 & -161.8638 & 439 & L4 & 1996/07/11 & - \\
\hline DRR3 & 54.9660 & -162.2631 & 457 & L4 & 1996/07/11 & - \\
\hline DT1 & 55.1062 & -162.2830 & 198 & L4 & $1991 / 06 / 21$ & - \\
\hline DTN & 55.1448 & -162.2590 & 396 & S13 & 1988/07/16 & - \\
\hline
\end{tabular}

Fourpeaked subnet

Station $\quad$ Latitude (N)

FONW $^{* \mathrm{P}} \quad 58.8341$

FOPK* $\quad 58.7574$

FOSS ${ }^{* \mathrm{P}} \quad 58.7987$

Mount Gareloi subnet

$\underline{\text { Station } \quad \text { Latitude (N) }}$

GAEA

51.7819

GAKI $\quad 51.5534$

GALA $\quad 51.7606$

GANE $\quad 51.8178$

GASW $^{3}$

51.7778
GANO $\quad 51.8192$

\begin{tabular}{c} 
Longitude (E) \\
\hline-153.6449 \\
-153.9204 \\
-153.4762 \\
-153.6971
\end{tabular}

Longitude (E)

$-178.7488$

$-178.8140$

$-178.7735$

$-178.7787$

$-178.8058$

$-178.8566$

\begin{tabular}{cll} 
Elevation (m) & & Seismometer \\
\cline { 1 - 1 } 622 & & S13 \\
905 & L-4 \\
546 & L4 \\
1,268 & L-4
\end{tabular}

Elevation (m)

326

99

315

325

451

248
Seismometer

L4

L4

L4

L4

L4

L22
Open date

1981/08/17

2006/10/19

2006/09/25

2006/10/19

Open date

2003/08/30

2003/09/01

2003/08/30

2003/09/02

2003/09/02

2003/08/30
Close date

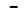

-

-

Close date

-

-

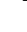

$-$

Great Sitkin Volcano subnet

\begin{tabular}{|c|c|c|}
\hline Station & Latitude $(\mathrm{N})$ & Longitude (E) \\
\hline GSCK & 52.0108 & -176.1640 \\
\hline GSIG & 51.9853 & -175.9270 \\
\hline GSMY & 52.0421 & -176.0583 \\
\hline GSSP & 52.0917 & -176.1777 \\
\hline GSTD $^{3}$ & 52.0548 & -176.1468 \\
\hline GSTR & 52.0932 & -176.0611 \\
\hline
\end{tabular}

Iliamna Volcano subnet

\begin{tabular}{|c|c|c|}
\hline Station & Latitude (N) & Longitude (E) \\
\hline$\overline{\mathrm{ILI}}$ & 60.0807 & -152.9606 \\
\hline ILS & 59.9570 & -153.0703 \\
\hline ILW & 60.0592 & -153.1392 \\
\hline INE & 60.0599 & -153.0644 \\
\hline $\operatorname{IVE}^{3}$ & 60.0163 & -153.0185 \\
\hline IVS & 60.0086 & -153.0830 \\
\hline
\end{tabular}

Kanaga Volcano subnet

Station Latitude (N) Longitude (E)

KICM $\quad 51.9178$

KIMD $\quad 51.7605$

KINC $\quad 51.9303$

KIRH

51.8985 $1996 / 07 / 25$
$-177.1973$

$-177.1724$

$-177.2369$

$-177.1296$

$-177.0955$

$-177.1528$

\begin{tabular}{cl} 
Elevation $(\mathbf{m})$ & Seismometer \\
\cline { 1 - 2 } 771 & L4 \\
1,125 & S13 \\
1,646 & S13 \\
1,634 & S13 \\
1,173 & S13,L22 \\
2,332 & S13
\end{tabular}

Open date

1987/09/15

$1996 / 08 / 28$

$1994 / 09 / 09$

$1990 / 08 / 29$

$1996 / 08 / 29$

$1990 / 08 / 29$

\begin{tabular}{cl} 
Elevation $(\mathbf{m})$ & Seismometer \\
\cline { 1 - 2 } 183 & L4 \\
411 & L4 \\
183 & L4 \\
198 & L4 \\
309 & L4 \\
244 & L4
\end{tabular}

Open date 1999/09/15 1999/09/15 $1999 / 09 / 15$ 1999/09/15 1999/09/03 1999/09/03

\begin{tabular}{cll} 
Elevation $(\mathbf{m})$ & Seismometer \\
\cline { 1 - 2 } 960 & & L22 \\
869 & L4 \\
807 & L4 \\
1,158 & L4 \\
940 & L4 \\
1,065 & CMT-6TD \\
1,250 & L4
\end{tabular}

Open date 1996/07/25 $1996 / 07 / 25$ $1996 / 07 / 25$ $1998 / 08 / 12$ 2004/08/01 $1998 / 10 / 12$

Close date

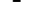

Close date

Close date

$-155.8858$

$-153.9716$

$-155.2843$

$-155.0081$
1,250

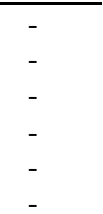

KABU

58.2702

58.6483 lose date 
Katmai Volcanic Cluster subnet (continued)

\begin{tabular}{|c|c|c|c|c|}
\hline Station & Latitude (N) & Longitude (E) & Elevation (m) & Seismometer \\
\hline KAHG & 58.4933 & -154.5484 & 923 & $\mathrm{~L} 4$ \\
\hline KAIC & 58.4843 & -155.0479 & 734 & L4 \\
\hline $\mathrm{KAKN}^{\mathrm{B}}$ & 58.2963 & -155.0623 & 1,049 & CMG-6TD \\
\hline $\mathrm{KAPH}^{3}$ & 58.5961 & -154.3489 & 907 & L22 \\
\hline KARR & 58.4971 & -154.7054 & 610 & L4 \\
\hline KAWH & 58.3830 & -154.8013 & 777 & L4 \\
\hline KBM & 58.2743 & -155.2038 & 732 & L4 \\
\hline $\mathrm{KCE}$ & 58.2426 & -155.1854 & 777 & L4 \\
\hline $\mathrm{KCG}^{3}$ & 58.3069 & -155.1135 & 762 & L22 \\
\hline KEL & 58.4393 & -155.7428 & 975 & L4 \\
\hline KJL & 58.0533 & -155.5753 & 792 & L4 \\
\hline KVT & 58.3810 & -155.2971 & 457 & L4 \\
\hline MGLS & 58.1336 & -155.1629 & 472 & L4 \\
\hline
\end{tabular}

Open date 1998/10/12 $1998 / 10 / 12$ $2004 / 08 / 01$ $1998 / 10 / 12$ $1998 / 10 / 12$ $1998 / 10 / 12$ $1991 / 07 / 22$ $1991 / 07 / 22$ $1988 / 08 / 01$ $1988 / 08 / 01$ $1996 / 07 / 25$ $1988 / 08 / 01$ $1996 / 07 / 25$

Open date 2004/07/02 $2004 / 07 / 05$ $2004 / 07 / 05$ $2004 / 07 / 10$ $2004 / 07 / 04$ 2004/07/07 2004/07/06

$-174.0992$

$-174.2022$

$-174.1673$

$-174.1213$

$-174.2125$

$-174.0505$

$-174.2527$

$\begin{array}{ll}\text { KOSE } & 52.3447 \\ \text { KOWE } & 52.3646\end{array}$

Little Sitkin subnet

$\begin{array}{lccc}\text { Station } & & \text { Latitude (N) } & \text { Longitude (E) } \\ \text { LSNW }^{3} & & 51.9693 & 178.5148 \\ \text { LSPA } & 51.9557 & 178.5714 \\ \text { LSSA } & 51.9484 & 178.5112 \\ \text { LSSE } & 51.9320 & 178.5670\end{array}$

Elevation (m)

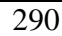

335

549

335

\begin{tabular}{l} 
Seismometer \\
\hline L4 \\
L4 \\
L22 \\
L4 \\
L4 \\
L4 \\
L4
\end{tabular}

Seismometer L4 L4-3D L4 L4

Open date 2005/09/30 $2005 / 09 / 30$ $2005 / 09 / 28$ $2005 / 09 / 27$

Makushin Volcano subnet

\begin{tabular}{|c|c|c|}
\hline Station & Latitude (N) & Longitude ( $\mathrm{E}$ \\
\hline$\overline{\text { MAPS }}^{\mathrm{B}}$ & 53.8082 & -166.9407 \\
\hline MCIR & 53.9505 & -166.8942 \\
\hline MGOD & 53.7938 & -166.8780 \\
\hline MGOD $^{\mathrm{B}}$ & 53.7938 & -166.8780 \\
\hline MNAT & 53.8829 & -166.6856 \\
\hline MNAT $^{\mathrm{B}}$ & 53.8829 & -166.6856 \\
\hline MREP & 53.8096 & -166.7476 \\
\hline $\mathrm{MSOM}^{\mathrm{R}}$ & 53.8154 & -166.9485 \\
\hline $\mathrm{MSW}^{3}$ & 53.9148 & -166.7880 \\
\hline $\mathrm{MSW}^{\mathrm{B}}$ & 53.9148 & -166.7880 \\
\hline MTBL & 53.9680 & -166.6813 \\
\hline
\end{tabular}

Elevation (m)

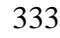

800

650

650

390

390

785

146

423

423

810

Seismometer
CMG-6TD
L4
L4
CMG-6TD
L4
CMG-6TD
L4
L4
L22
CMG-6TD
L4

Open date 2012/08/03 $1996 / 07 / 25$ $1996 / 07 / 25$ 2012/08/03 $1996 / 07 / 25$ 2002/01/01 $1996 / 07 / 25$ $1996 / 07 / 25$ 2011/08/04 $1996 / 07 / 25$ 2012/08/03

Close date

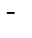

Close date

Close date

Close date

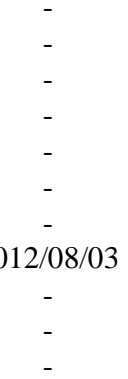

Okmok Caldera subnet

\begin{tabular}{|c|c|c|c|c|c|}
\hline$\underline{\text { Station }}$ & Latitude (N) & Longitude (E) & Elevation (m) & $\underline{\text { Seismometer }}$ & $\underline{\text { Open date }}$ \\
\hline$\overline{\mathrm{OKAK}}$ & 53.4113 & -168.3600 & 165 & $\overline{\mathrm{L} 4}$ & $\overline{2005 / 07 / 11}$ \\
\hline $\mathrm{OKCE}^{\mathrm{B}}$ & 53.4260 & -168.1663 & 515 & CMG-6TD & 2003/01/09 \\
\hline OKCF & 53.3948 & -168.1382 & 685 & L4 & 2003/01/09 \\
\hline OKER & 53.4536 & -168.0513 & 956 & L4 & 2003/01/09 \\
\hline $\mathrm{OKFG}^{\mathrm{B}}$ & 53.4107 & -167.9115 & 201 & CMG-6TD & 2003/01/09 \\
\hline OKID & 53.4764 & -167.8182 & 437 & L4 & 2003/01/09 \\
\hline OKIF $^{\mathrm{I}}$ & 53.4108 & -167.9143 & 221 & $25 \mathrm{Vx}$ & 2010/09/01 \\
\hline $\mathrm{OKNC}^{\mathrm{B}}$ & 53.4559 & -168.1257 & 404 & CMG-6TD & 2010/09/01 \\
\hline OKRE & 53.5192 & -168.1661 & 422 & L4 & 2003/01/09 \\
\hline $\mathrm{OKSO}^{\mathrm{B}}$ & 53.3565 & -168.1619 & 460 & CMG-6TD & 2004/09/01 \\
\hline OKSP & 53.2516 & -168.2925 & 608 & $\mathrm{~L} 4$ & 2003/01/09 \\
\hline
\end{tabular}

Close date

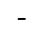

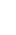


Okmok Caldera subnet (continued)

\begin{tabular}{|c|c|c|c|c|c|c|}
\hline Station & Latitude (N) & Longitude (E) & Elevation (m) & $\underline{\text { Seismometer }}$ & Open date & $\underline{\text { Close date }}$ \\
\hline$\overline{\mathrm{OKTU}}$ & 53.3829 & -168.0431 & 646 & $\overline{\mathrm{L} 4}$ & $\overline{2003 / 01 / 09}$ & - \\
\hline OKWE & 53.4711 & -168.2418 & 445 & L4 & 2003/01/09 & - \\
\hline OKWR & 53.4337 & -16.2076 & 1,017 & L4 & 2003/01/09 & - \\
\hline
\end{tabular}

\section{Pavlof Volcano subnet}

$\underline{\text { Station } \quad \text { Latitude (N) }}$

BLHA $\quad 55.7038$

HAG

55.7038
55.3170

Longitude (E)

$-162.0611$

$-161.9045$

PN7A $^{\mathrm{P}}$

55.4329

$-161.9973$

$-161.7437$

PS4A

55.4201

PV6 $^{3}$

55.3460

$-161.8567$

$-161.9205$

PVV

55.3732

$-161.7919$

\begin{tabular}{|c|c|}
\hline Elevation (m) & Seismometer \\
\hline 411 & L4 \\
\hline 516 & L4 \\
\hline 838 & L4 \\
\hline 283 & L4 \\
\hline 322 & L4 \\
\hline 747 & L22 \\
\hline 173 & L4 \\
\hline
\end{tabular}

Open date

1996/07/11

$1996 / 07 / 11$

$1996 / 07 / 11$

$1996 / 07 / 11$

$1996 / 07 / 11$

$1996 / 07 / 11$

$1996 / 07 / 11$

Mount Peulik subnet

\begin{tabular}{|c|c|c|}
\hline$\underline{\text { Station }}$ & Latitude (N) & Longitude (E) \\
\hline$\overline{\text { PLBL }}$ & 57.6991 & -156.8210 \\
\hline PLK1 & 57.8012 & -156.6093 \\
\hline PLK2 & 57.7635 & -156.3264 \\
\hline $\mathrm{PLK3}^{3}$ & 57.6880 & -156.2695 \\
\hline PLK4 & 57.6314 & -156.3598 \\
\hline PLK5 & 57.9970 & -156.8798 \\
\hline PLWL & 58.0442 & -156.3434 \\
\hline
\end{tabular}

Elevation (m) Seismometer

$\frac{\text { Open date }}{2004 / 08 / 01}$
$2004 / 08 / 01$
$2004 / 08 / 01$
$2004 / 08 / 01$
$2004 / 08 / 01$
$2004 / 08 / 01$
$2004 / 08 / 01$

Close date

$\begin{array}{ccl}461 & & \text { L4 } \\ 78 & & \text { L4 } \\ 401 & & \text { L4 } \\ 494 & & \text { L22 } \\ 1,031 & & \text { L4 } \\ 49 & & \text { L4 } \\ 585 & & \text { L4 }\end{array}$

Redoubt Volcano subnet

\begin{tabular}{|c|c|c|}
\hline Station & Latitude (N) & Longitude (E) \\
\hline$\overline{\mathrm{DFR}^{\mathrm{P}}}$ & 60.5913 & -152.6882 \\
\hline NCT & 60.5615 & -152.9316 \\
\hline $\mathrm{NCT}^{\mathrm{B}}$ & 60.5621 & -152.9293 \\
\hline $\mathrm{RDDF}^{\mathrm{B}}$ & 60.5912 & -152.6883 \\
\hline RDDR & 60.5843 & -152.5887 \\
\hline $\mathrm{RDJH}^{\mathrm{B}}$ & 60.5905 & -152.8058 \\
\hline RDN & 60.5224 & -152.7401 \\
\hline $\mathrm{RDSO}^{\mathrm{B}}$ & 60.4536 & -152.7453 \\
\hline RDT & 60.5726 & -152.4075 \\
\hline $\mathrm{RDWB}^{\mathrm{B}}$ & 60.4875 & -152.8424 \\
\hline $\mathrm{RED}^{3}$ & 60.4196 & -152.7742 \\
\hline $\mathrm{RED}^{\mathrm{B}}$ & 60.4196 & -152.7742 \\
\hline $\mathrm{REF}^{3 *}$ & 60.4888 & -152.6940 \\
\hline RSO & 60.4616 & -152.7560 \\
\hline
\end{tabular}

\begin{tabular}{|c|c|}
\hline Elevation (m) & Seismometer \\
\hline 1,090 & L4 \\
\hline 1,120 & L4 \\
\hline 1,136 & CMG-6TD \\
\hline 1,134 & CMG-6TD \\
\hline 905 & L4 \\
\hline 1,414 & CMG-6TD \\
\hline 1,400 & L4 \\
\hline 1,557 & CMG-6TD \\
\hline 930 & L4 \\
\hline 1,546 & CMG-6TD \\
\hline 1,071 & L4 \\
\hline 1,071 & CMG-6TD \\
\hline 1,641 & L22 \\
\hline 1,921 & L4 \\
\hline
\end{tabular}

Open date 1988/08/15 $1988 / 08 / 14$ $2011 / 08 / 24$ $2010 / 01 / 11$

$2009 / 07 / 01$ 2009/02/04 $1988 / 08 / 13$ $2011 / 08 / 29$ $1971 / 08 / 09$ $2009 / 02 / 24$ $1990 / 08 / 30$ $2011 / 08 / 24$ $1990 / 03 / 14$ 1990/03/01

\section{Shishaldin Volcano subnet}

\begin{tabular}{lccc} 
Station & Latitude (N) & Longitude (E) \\
\cline { 2 - 2 } BRPK & 54.6446 & & -163.7428 \\
ISLZ & 54.7251 & -163.7130 \\
ISNN & 54.8314 & -163.7804 \\
SSBA $^{\text {B }}$ & 54.7718 & -164.1265 \\
SSLN $^{\text {P }}$ & 54.8109 & -163.9979 \\
SSLS $^{3}$ & 54.7111 & -164.0008 \\
SSLW & 54.7709 & -164.1234
\end{tabular}

Mount Spurr subnet

\begin{tabular}{|c|c|c|}
\hline$\underline{\text { Station }}$ & Latitude (N) & Longitude (E) \\
\hline$\overline{\mathrm{BGL}}$ & 61.2663 & -152.3913 \\
\hline BKG & 61.0696 & -152.2650 \\
\hline CGL & 61.3071 & -152.0090 \\
\hline CKL & 61.1958 & -152.3400 \\
\hline $\mathrm{CKN}$ & 61.2234 & -152.1838 \\
\hline CKT & 61.2002 & -152.2085 \\
\hline СР2 & 61.2636 & -152.2441 \\
\hline
\end{tabular}

\begin{tabular}{cll} 
Elevation $(\mathbf{m})$ & & Seismometer \\
\cline { 1 - 2 } 393 & & L4 \\
631 & L4 \\
466 & L4 \\
766 & CMG-6TD \\
637 & L4 \\
817 & L22 \\
636 & L4
\end{tabular}

\begin{tabular}{l} 
Open date \\
\hline $1997 / 07 / 27$ \\
$2008 / 08 / 17$ \\
$1997 / 07 / 27$ \\
$2008 / 08 / 01$ \\
$1997 / 07 / 27$ \\
$1997 / 07 / 27$ \\
$1997 / 07 / 27$
\end{tabular}

Close date
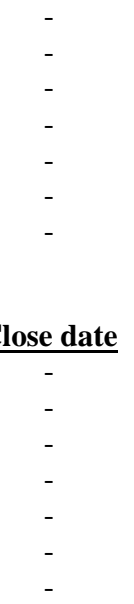

Close date

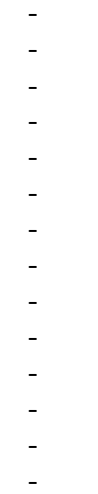

Close date

\begin{tabular}{|c|c|}
\hline Elevation (m) & $\underline{\text { Seismometer }}$ \\
\hline 1,127 & $\mathrm{~L} 4$ \\
\hline 1,009 & L4 \\
\hline 1,082 & L4 \\
\hline 1,281 & L4 \\
\hline 735 & L4 \\
\hline 975 & L4 \\
\hline 1,981 & L4 \\
\hline
\end{tabular}

$\frac{\text { Open date }}{1989 / 08 / 13}$
$1991 / 07 / 01$
$1981 / 09 / 22$
$1989 / 08 / 05$
$1991 / 09 / 19$
$1992 / 09 / 16$
$1992 / 10 / 23$

Close date 
Mount Spurr subnet (continued)

\begin{tabular}{|c|c|c|c|c|}
\hline Station & Latitude (N) & Longitude (E) & Elevation (m) & Seismometer \\
\hline$\overline{\mathrm{CRP}^{3}}$ & 61.2664 & -152.1578 & $\begin{array}{c}1,622 \\
\end{array}$ & $\overline{\mathrm{L} 4}$ \\
\hline NCG & 61.4031 & -152.1590 & 1,244 & L4 \\
\hline $\mathrm{SPBG}^{\mathrm{B}}$ & 61.2591 & -152.3722 & 1,087 & CMG-6TD \\
\hline $\mathrm{SPCG}^{\mathrm{B}}$ & 61.2913 & -152.0228 & 1,329 & CMG-6TD \\
\hline $\mathrm{SPCN}^{\mathrm{B}}$ & 61.2244 & -152.1854 & 735 & CMG-6TD \\
\hline $\mathrm{SPCP}^{\mathrm{B}}$ & 61.2655 & -152.1550 & 1,616 & CMG-6TD \\
\hline $\mathrm{SPCR}^{\mathrm{B}}$ & 61.2003 & -152.2091 & 984 & CMG-6TD \\
\hline SPNN $^{B}$ & 61.3662 & -152.7012 & 1,666 & CMG-6TD \\
\hline SPU & 61.1811 & -152.0566 & 800 & L4 \\
\hline SPWE & 61.2728 & -152.5614 & 1,327 & L4 \\
\hline
\end{tabular}

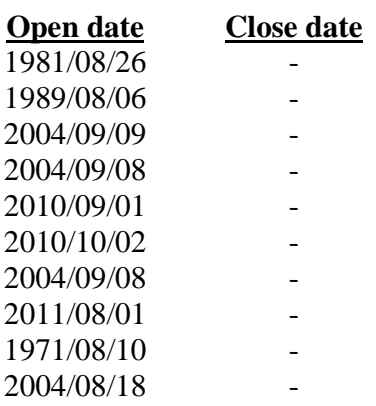

Tanaga Volcano subnet

TAFL $\quad 51.7555$

Station $\quad$ Latitude (N)

TACS 51.8621

TAFP $^{3} \quad 51.8990$

TANO $\quad 51.9146$

TAPA $\quad 51.8144$

TASE

51.8339

Longitude (E)

$-178.1414$

$-177.8998$

$-177.9853$

$-178.1228$

$-177.8148$

$-178.0390$

Mount Veniaminof subnet

$\frac{\text { Station }}{\mathrm{BPBC}} \quad \frac{\text { Latitude (N) }}{56.5889}$

BPBC

VNFG

VNHG

VNKR

VNNF

VNSG

VNSS

VNSW

VNWF

56.2849

56.2203

56.0304

56.2829

56.1250

56.2259

56.0712

56.1509

Westdahl Peak subnet

Station $\quad$ Latitude (N)

WEBT

WECS

WESE

WESN

WESP $^{3}$

WTUG

54.5902

54.5300

54.4723

54.5761

54.4926

\begin{tabular}{c} 
Longitude (E) \\
\hline-158.4547 \\
-159.5532 \\
-159.1663 \\
-159.3699 \\
-159.3181 \\
-159.0875 \\
-159.4569 \\
-159.5606 \\
-159.5643
\end{tabular}

Longitude (E) $-164.7550$

$-164.7796$

$-164.5860$

$-164.5804$

$-164.7233$

$-164.3873$
54.8466

Mount Wrangell subnet

$\frac{\text { Station }}{\text { WACK }^{3}} \quad \frac{\text { Latitude (N) }}{61.9858}$

WANC $\quad 62.0027$

WASW $\quad 61.9277$

WAZA

62.0746

\section{AVO Regional stations}

$\begin{array}{lcc}\text { Station } & \text { Latitude }(\mathbf{N}) & \text { Longitude (E) } \\ \text { ADAG } & 51.9791 & -176.6037 \\ \text { AMKA }^{\text {B }} & 51.3771 & 179.3000 \\ \text { BGM } & 59.3920 & -155.2315 \\ \text { BGR } & 60.7569 & -152.4199 \\ \text { ETKA } & 51.8608 & -176.4079 \\ \text { MMN } & 59.1845 & -154.3389 \\ \text { OPT } & 59.6526 & -153.2321 \\ \text { PDB } & 59.7841 & -154.1917 \\ \text { STLK } & 61.4982 & -151.8349 \\ \text { SYI } & 58.6094 & -152.3935\end{array}$

\begin{tabular}{cll} 
Elevation (m) & & Seismometer \\
\cline { 1 - 2 } 918 & L4 \\
186 & L4 \\
440 & L22 \\
269 & L4 \\
640 & L4 \\
682 & L4
\end{tabular}

\begin{tabular}{cll} 
Elevation $(\mathbf{m})$ & & Seismometer \\
\cline { 1 - 1 } 584 & & L4 \\
1,068 & L4 \\
966 & L4 \\
620 & L4 \\
1,153 & L4 \\
761 & L4 \\
1,733 & L4 \\
716 & L4 \\
1,095 & L4
\end{tabular}

Elevation (m) 467

642

953

549

937

636

\begin{tabular}{l} 
Seismometer \\
\hline L4 \\
L4 \\
L4 \\
L4 \\
L22 \\
L4
\end{tabular}

Open date 2008/08/02 2008/08/04 $1998 / 08 / 28$ $1998 / 10 / 17$ 2008/07/31 $1998 / 10 / 17$

\begin{tabular}{|c|c|}
\hline Elevation (m) & Seismometer \\
\hline 2,280 & $\overline{\mathrm{L} 22}$ \\
\hline 4,190 & L4 \\
\hline 2,196 & L4 \\
\hline 2,531 & L4 \\
\hline
\end{tabular}

Open date 2000/07/31 $2000 / 07 / 31$ 2001/08/03 2001/08/03

\begin{tabular}{cll} 
Elevation $(\mathbf{m})$ & Seismometer \\
\cline { 1 - 2 } 286 & L4 \\
116 & Tri-40 \\
625 & L4 \\
985 & L4 \\
290 & L4 \\
442 & S13 \\
602 & S13 \\
360 & L4 \\
945 & L4 \\
149 & L4
\end{tabular}

$\frac{\text { Open date }}{1999 / 09 / 15}$
$2005 / 10 / 14$
$1978 / 09 / 08$
$1991 / 07 / 01$
$1999 / 09 / 15$
$1981 / 08 / 22$
$1974 / 01 / 01$
$1978 / 09 / 09$
$1997 / 09 / 01$
$1997 / 09 / 01$
Close date

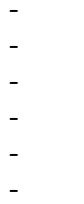

Close date

Close date

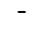

Close date

-

Close date

-

- 


\begin{tabular}{|c|c|c|c|c|c|c|}
\hline \multicolumn{7}{|c|}{ Previously Closed AVO Stations } \\
\hline$\underline{\text { Station }}$ & Latitude (N) & Longitude (E) & Elevation (m) & $\underline{\text { Seismometer }}$ & Open date & Close date \\
\hline AJAX & 56.8887 & -158.2238 & 967 & $\overline{\mathrm{L}-4}$ & $2000 / 07 / 10$ & $2002 / 07 / 12$ \\
\hline AK1 & 54.1350 & -165.7720 & 12 & L-4 & 1996/03/18 & 1997/08/08 \\
\hline AK2 & 54.1233 & -165.7803 & 90 & L-4 & $1996 / 03 / 18$ & 1997/08/08 \\
\hline AK1 & 54.1350 & -165.7720 & 12 & L-4 & $1996 / 03 / 18$ & 1997/08/08 \\
\hline AK3 & 54.1233 & -165.7803 & 12 & L-4 & 1996/03/18 & 1997/08/08 \\
\hline AK4 & 54.1091 & -165.7337 & 135 & L-4 & 1996/03/17 & 1997/08/08 \\
\hline AK5 & 54.1543 & -165.8670 & 225 & L-4 & $1996 / 03 / 21$ & 1997/08/08 \\
\hline ANIA & 56.9048 & -158.2316 & 930 & L-4 & 1997/07/18 & $2000 / 07 / 10$ \\
\hline ANSL & 56.9316 & -158.1385 & 344 & L-22 & 1997/07/18 & 2000/07/09 \\
\hline AU11 & 59.3590 & -153.4826 & 324 & CMG-6TD & $2005 / 12 / 20$ & 2006/02/12 \\
\hline AU12 & 59.3829 & -153.4542 & 210 & CMG-6TD & $2005 / 12 / 20$ & 2006/01/30 \\
\hline AU13 & 59.3458 & -153.4364 & 518 & CMG-6TD & $2005 / 12 / 20$ & 2006/05/30 \\
\hline AU14 & 59.3705 & -153.3992 & 303 & CMG-6TD & $2005 / 12 / 21$ & 2006/08/07 \\
\hline AU15 & 59.3501 & -153.4879 & 168 & CMG-6TD & $2005 / 12 / 21$ & 2006/08/10 \\
\hline AU20 & 59.3696 & -153.3563 & 102 & ANSS130-02/3 & $2006 / 01 / 09$ & 2006/09/01 \\
\hline AU31 & 59.3683 & -153.2534 & -49 & MP-L28 & 2006/02/09 & 2006/03/26 \\
\hline AU32 & 59.4683 & -153.4016 & -25 & MP-L28 & 2006/02/09 & $2006 / 03 / 26$ \\
\hline AU33 & 59.4247 & -153.5652 & -27 & MP-L28 & $2006 / 02 / 09$ & $2006 / 03 / 26$ \\
\hline AU34 & 59.2735 & -153.5471 & -32 & MP-L28 & 2006/02/09 & $2006 / 03 / 26$ \\
\hline AU35 & 59.2298 & -153.3960 & -49 & MP-L28 & 2006/02/09 & $2006 / 03 / 26$ \\
\hline AUC & 59.3593 & -153.4268 & 1,175 & L-4 & $1995 / 09 / 13$ & 2003/10/06 \\
\hline AUD & 59.3620 & -153.4288 & 1,208 & L-4 & 1994/09/06 & 1996/08/07 \\
\hline AUR & 59.3621 & -153.4335 & 1,225 & L-4 & 1995/11/01 & 2006/01/11 \\
\hline AUS & 59.3593 & -153.4329 & 1,226 & S13 & 1990/09/01 & 2006/01/11 \\
\hline AUSE & 59.3407 & -153.3997 & 152 & L-4 & 2006/02/03 & 2011/08/16 \\
\hline CPA & 61.2542 & -152.1436 & 1,622 & L-22 & $1992 / 10 / 29$ & $1994 / 01 / 01$ \\
\hline CPK & 61.2627 & -152.2354 & 2,017 & L-4 & 1991/10/01 & 1994/01/01 \\
\hline CRB & 61.2664 & -152.1578 & 1,622 & CMG-40T & 1991/10/01 & 1995/08/18 \\
\hline CH05 & 57.1575 & -157.0313 & 617 & CMG-6TD & $2005 / 08 / 26$ & $2005 / 09 / 25$ \\
\hline DRE & 60.5826 & -152.5891 & 489 & L-4 & 1990/02/01 & 1994/01/01 \\
\hline FP01 & 58.8129 & -153.7581 & 844 & CMG-6TD & 2006/09/24 & 2006/10/08 \\
\hline INW & 60.0670 & -153.1347 & 1,219 & L-4 & $1990 / 08 / 29$ & $1994 / 01 / 01$ \\
\hline ISTK & 54.7312 & -163.7083 & 704 & $\mathrm{~L}-4$ & $1997 / 07 / 27$ & 2008/08/12 \\
\hline $\mathrm{KA} 1^{\#}$ & 58.3136 & -155.0937 & 810 & CMG-6TD & $2008 / 07 / 20$ & $2010 / 07 / 10$ \\
\hline $\mathrm{KA} 2^{\#}$ & 58.2512 & -155.1543 & 999 & CMG-3ESP & $2008 / 07 / 20$ & 2009/08/15 \\
\hline $\mathrm{KA03}^{\#}$ & 58.2595 & -155.1336 & 1,015 & CMG-6TD & $2008 / 07 / 20$ & $2010 / 07 / 10$ \\
\hline${\mathrm{KA} 04^{\#}}^{\#}$ & 58.2219 & -155.1465 & 994 & CMG-6TD & $2008 / 07 / 20$ & 2010/07/10 \\
\hline $\mathrm{KA}^{\circ} 5^{\#}$ & 58.2150 & -155.0870 & 935 & CMG-6TD & $2008 / 07 / 20$ & $2010 / 07 / 10$ \\
\hline $\mathrm{KA} 6^{\#}$ & 58.2103 & -155.0213 & 1,003 & CMG-6TD & $2008 / 07 / 20$ & 2009/08/15 \\
\hline KA11 ${ }^{\#}$ & 58.2827 & -155.1416 & 1,098 & CMG-6TD & $2008 / 07 / 20$ & $2010 / 07 / 10$ \\
\hline KA12 & 58.2311 & -155.2690 & 884 & CMG-6TD & 2008/07/20 & 2009/08/15 \\
\hline $\mathrm{KA} 3^{\#}$ & 58.2204 & -155.1941 & 899 & CMG-3ESP & $2008 / 07 / 20$ & $2009 / 08 / 15$ \\
\hline KA15 & 58.1922 & -155.1880 & 926 & CMG-6TD & $2008 / 07 / 20$ & $2010 / 07 / 10$ \\
\hline KA16 & 58.1793 & -155.1023 & 714 & CMG-6TD & $2008 / 07 / 20$ & $2009 / 08 / 15$ \\
\hline OKAS & 53.4043 & -168.3634 & 270 & L-4 & 2003/01/09 & $2005 / 07 / 10$ \\
\hline OKCВ & 53.4559 & -168.1257 & 404 & CMG-6TD & $2010 / 07 / 25$ & 2008/09/01 \\
\hline OKCD & 53.4293 & -168.1143 & 459 & CMG-6TD & $2003 / 01 / 09$ & 2008/07/12 \\
\hline PV01 & 55.4390 & -161.9414 & 852 & CMG-6TD & 2007/09/23 & 2008/07/18 \\
\hline PV02 & 55.4061 & -161.8050 & 458 & CMG-6TD & $2007 / 09 / 22$ & $2008 / 07 / 22$ \\
\hline PV03 & 55.3704 & -161.8676 & 601 & CMG-6TD & 2007/09/24 & $2008 / 07 / 21$ \\
\hline RD01 & 60.4885 & -152.7031 & 1,831 & CMG-6TD & 2009/03/21 & 2009/06/09 \\
\hline RD02 & 60.5208 & -152.7376 & 1,401 & CMG-6TD & $2009 / 03 / 20$ & $2009 / 06 / 10$ \\
\hline RD03 & 60.4705 & -152.8201 & 1,607 & CMG-6TD & 2009/03/20 & 2009/06/10 \\
\hline RDE & 60.5869 & -152.5925 & 571 & $\mathrm{~L}-4$ & 2009/02/04 & 2009/07/01 \\
\hline RDW & 60.5208 & -152.7376 & 1,401 & L-4 & 1990/09/07 & 1996/03/17 \\
\hline RDW & 60.5208 & -152.7376 & 1,401 & CMG-6TD & 2009/03/21 & 2009/07/01 \\
\hline RWS & 60.4874 & -152.7768 & 2,713 & $\mathrm{~L}-4$ & $1990 / 03 / 13$ & $1994 / 01 / 01$ \\
\hline
\end{tabular}




\begin{tabular}{|c|c|c|c|c|c|c|}
\hline \multicolumn{7}{|c|}{ Previously Closed AVO Stations (continued) } \\
\hline Station & Latitude (N) & Longitude (E) & Elevation (m) & $\underline{\text { Seismometer }}$ & Open date & Close date \\
\hline$\overline{\text { SP02 }}$ & 61.1763 & -152.0602 & 821 & $\overline{\text { CMG-6TD }}$ & $2005 / 06 / 16$ & $\overline{2005 / 09 / 14}$ \\
\hline SP03 & 61.1362 & -152.0491 & 882 & CMG-6TD & 2005/06/16 & 2005/09/14 \\
\hline SP04 & 61.1330 & -152.2588 & 946 & CMG-6TD & $2005 / 06 / 16$ & $2005 / 09 / 14$ \\
\hline SP05 & 61.3460 & -152.0906 & 893 & CMG-6TD & 2005/06/16 & 2005/09/14 \\
\hline SP06 & 61.2592 & -152.1865 & 1,192 & CMG-6TD & $2005 / 06 / 16$ & 2005/09/14 \\
\hline SP07 & 61.3458 & -151.9662 & 1,113 & CMG-6TD & 2005/06/16 & 2005/09/14 \\
\hline SP08 & 61.3320 & -152.4473 & 1,545 & CMG-6TD & $2005 / 06 / 16$ & 2005/09/14 \\
\hline SP09 & 61.2350 & -151.8009 & 814 & CMG-6TD & 2005/06/16 & 2005/09/14 \\
\hline SP10 & 61.3738 & -152.5187 & 1,429 & CMG-6TD & $2005 / 06 / 16$ & $2005 / 09 / 14$ \\
\hline SP11 & 61.1791 & -152.6232 & 921 & CMG-6TD & $2005 / 06 / 16$ & $2005 / 09 / 14$ \\
\hline SP12 & 61.3932 & -152.1352 & 1,034 & CMG-6TD & 2005/06/16 & 2005/09/14 \\
\hline SPNW & 61.3465 & -152.6062 & 1,040 & L-4 & $2004 / 08 / 17$ & 2011/08/01 \\
\hline WESS & 54.4796 & -164.7242 & 908 & L-22 & $1998 / 08 / 28$ & 2008/07/31 \\
\hline WFAR & 54.5329 & -164.7781 & 640 & L-4 & $1998 / 08 / 28$ & 2008/08/03 \\
\hline WPOG & 54.5964 & -164.7454 & 445 & L-4 & 1998/10/17 & 2008/08/02 \\
\hline
\end{tabular}

\begin{tabular}{|c|c|c|c|c|c|c|}
\hline Station & Latitude (N) & Longitude (E) & Elevation (m) & $\underline{\text { Seismometer }}$ & Open date & Close date \\
\hline$\overline{\mathrm{ADK}}$ & 51.8823 & -176.6842 & 130 & $\overline{\text { STS-1 }}$ & $\overline{1966 / 01 / 01}$ & - \\
\hline AKUT & 54.1340 & -165.7719 & 192 & TRI-40 & 2004/11/18 & - \\
\hline ATKA & 52.2016 & -174.1975 & 55 & CMG-3ESP & 2002/10/03 & - \\
\hline BAL & 61.0358 & -142.3462 & 1,341 & L4 & $1973 / 08 / 24$ & 2010/06/17 \\
\hline BAL & 61.0358 & -142.3462 & 1,341 & TRI-40 & 2010/06/18 & - \\
\hline BMR & 60.9677 & -144.6051 & 842 & CMG-40T & 2000/08/08 & - \\
\hline CHGN & 56.3006 & -159.4162 & 16 & L4 & $2004 / 10 / 20$ & 2011/08/09 \\
\hline CHGN & 56.3014 & -159.4142 & 170 & STS-2 & 2011/08/10 & - \\
\hline CHI & 55.8218 & -155.6225 & 203 & TRI-40 & 2008/09/17 & - \\
\hline CNP & 59.5253 & -155.2370 & 572 & L4 & 1983/07/01 & $2008 / 07 / 24$ \\
\hline CNP & 59.5251 & -155.2373 & 564 & TRI-40 & $2008 / 07 / 25$ & - \\
\hline CUT & 62.4061 & -150.2629 & 163 & L4 & 1986/07/18 & - \\
\hline DHY & 63.0752 & -147.3760 & 1,611 & L4 & $1993 / 07 / 06$ & 2008/07/09 \\
\hline DHY & 63.0753 & -147.3759 & 1,611 & TRI-40 & 2008/07/10 & - \\
\hline DIV & 61.1292 & -145.7749 & 941 & CMG-3ESP & 1999/01/07 & - \\
\hline FALS & 54.8564 & -163.4175 & 46 & CMG-3ESP & $2002 / 06 / 19$ & - \\
\hline FIB & 61.1656 & -150.1775 & 62 & CMG-40T & 1996/01/04 & - \\
\hline $\mathrm{GHO}$ & 61.7710 & -148.9260 & 1,041 & L4 & 1984/09/12 & $2011 / 05 / 29$ \\
\hline GHO & 61.7710 & -148.9260 & 1,041 & TRI-40 & 2011/05/30 & - \\
\hline GLB & 61.4417 & -143.8123 & 853 & L4 & $1973 / 08 / 25$ & 2010/09/11 \\
\hline GLB & 61.4417 & -143.8123 & 853 & L22 & 2010/09/12 & - \\
\hline HARP & 62.3986 & -145.1567 & 583 & CMG-40T & 2002/11/09 & - \\
\hline HOM & 59.6572 & -151.6525 & 221 & L4 & $1981 / 01 / 01$ & 2009/06/18 \\
\hline HOM & 59.6572 & -151.6525 & 221 & TRI-40 & 2009/06/19 & - \\
\hline KDAK & 57.7828 & -152.5835 & 152 & KS-54000 & 1997/06/09 & - \\
\hline KLU & 61.4925 & -145.9228 & 1,042 & L4 & $1972 / 07 / 23$ & 2008/09/13 \\
\hline KLU & 61.4925 & -145.9228 & 1,042 & TRI-40 & 2008/09/14 & - \\
\hline KNK & 61.4120 & -148.4578 & 595 & L4 & 1973/08/11 & 2010/06/12 \\
\hline KNK & 61.4120 & -148.4578 & 595 & TRI-40 & 2010/06/13 & - \\
\hline KTH & 63.5527 & -150.9232 & 1,172 & L4 & $1988 / 05 / 08$ & 2003/06/07 \\
\hline KTH & 63.5527 & -150.9232 & 1,172 & CMG-3T & 2003/06/08 & - \\
\hline MENT & 62.9376 & -143.7216 & 702 & L4 & $2004 / 10 / 20$ & 2010/12/01 \\
\hline MENT & 62.9380 & -143.7194 & 702 & TRI-40 & 2010/12/02 & - \\
\hline MSP & 60.4882 & -149.3633 & 168 & L4 & $1973 / 08 / 05$ & - \\
\hline NIKH & 52.9721 & -168.8550 & 199 & STS-2 & $2007 / 06 / 21$ & - \\
\hline NIKO & 52.9378 & -168.8687 & 80 & CMG-3ESP & $2002 / 11 / 22$ & $2009 / 05 / 22$ \\
\hline NKA & 60.7424 & -151.2401 & 100 & L4 & 1971/09/13 & $2012 / 09 / 20$ \\
\hline NKA & 60.7425 & -151.2395 & 448 & TRI-40 & 2012/09/21 & - \\
\hline PAX & 62.9699 & -145.4698 & 1,130 & S13 & 1969/07/01 & 2003/10/05 \\
\hline PAX & 62.9699 & -145.4699 & 1,150 & STS-2 & $2003 / 10 / 05$ & - \\
\hline PLR & 61.5917 & -149.1329 & 100 & L4 & $1984 / 09 / 21$ & 2009/02/25 \\
\hline
\end{tabular}




\section{AEIC, Global Seismograph Network and WCATWC stations (continued)}

\begin{tabular}{|c|c|c|c|c|c|c|}
\hline Station & Latitude (N) & Longitude (E) & Elevation (m) & $\underline{\text { Seismometer }}$ & Open date & Close date \\
\hline$\overline{\mathrm{PMR}}$ & 61.5922 & -149.1308 & 100 & $\overline{\text { STS-2 }}$ & $\overline{1999 / 08 / 11}$ & - \\
\hline RC01 & 61.0890 & -149.7390 & 383 & CMG-40T & $1998 / 08 / 07$ & - \\
\hline SAW & 61.8071 & -148.3317 & 782 & L4 & 1973/08/31 & 1999/11/06 \\
\hline SAW & 61.8070 & -148.3318 & 847 & CMG-3ESP & 1999/11/07 & - \\
\hline SCM & 61.8329 & -147.3296 & 1,039 & S13 & 1966/06/01 & 2008/07/17 \\
\hline SCM & 61.8329 & -147.3296 & 1,039 & TRI-40 & 2008/07/18 & - \\
\hline SDG & 62.5271 & -145.5483 & 634 & $\mathrm{~S} 13$ & $1986 / 01 / 01$ & $2008 / 10 / 29$ \\
\hline SDPT & 55.3485 & -160.4786 & 74 & STS-2 & $2002 / 08 / 28$ & - \\
\hline SKN & 61.9800 & -151.5315 & 603 & L4 & $1972 / 08 / 09$ & 2006/05/14 \\
\hline SKN & 61.9800 & -151.5317 & 581 & STS-2 & 2006/05/15 & - \\
\hline SLK & 60.5117 & -150.2231 & 655 & L4 & 1984/07/30 & - \\
\hline SSN & 61.4634 & -150.7467 & 1,293 & L4 & $1972 / 08 / 16$ & 2008/09/16 \\
\hline SSN & 61.4636 & -150.7467 & 1,306 & CMG-5T & 2008/09/17 & - \\
\hline SWD & 60.1031 & -149.4513 & 91 & L4 & $1972 / 08 / 23$ & 2001/06/02 \\
\hline SWD & 60.1043 & -149.4526 & 77 & CMG-40T & 2001/06/02 & - \\
\hline TRF & 63.4505 & -150.2896 & 1,717 & S13 & 1989/08/15 & 2003/06/05 \\
\hline TRF & 63.4505 & -150.2896 & 1,717 & CMG-3ESP & 2003/06/05 & - \\
\hline UNV & 53.8456 & -166.5040 & 67 & CMG-3ESP & 1999/02/19 & - \\
\hline
\end{tabular}

\begin{tabular}{|c|c|c|}
\hline Station Codes: & $\begin{array}{ll}3 & \text { Three-co } \\
\text { B } & \text { Three-co } \\
\text { I } & \text { Stand-alo } \\
\text { P } & \text { Infrasoun } \\
\text { R } & \text { Station re } \\
\text { S } & \text { Three-co } \\
\text { * } & \text { Seismic S } \\
\text { \# } & \text { Tempora }\end{array}$ & $\begin{array}{l}\text { mponent short-period station } \\
\text { mponent broadband station } \backslash \\
\text { one infrasound station } \\
\text { ad sensor collocated with seismometer } \\
\text { emoved in } 2012 \\
\text { mponent strong motion station } \\
\text { tation has a both a high-gain and low-gain vertical component } \\
\text { ry three-component broadband station }\end{array}$ \\
\hline Seismometer Codes: & $\begin{array}{l}\text { 130-ANSS/02: } \\
\text { 25Vx: } \\
\text { CMG-3T: } \\
\text { CMG-40T: } \\
\text { CMG-5T: } \\
\text { CMG-6TD: } \\
\text { CMG-3ESP: } \\
\text { KS-54000: } \\
\text { L4, L4-3D: } \\
\text { L22: } \\
\text { MP-L28: } \\
\text { S13: } \\
\text { STS-2: } \\
\text { Tri-40: }\end{array}$ & $\begin{array}{l}\text { Ref Tek 130-ANSS/02 strong motion seismometer } \\
\text { Chaparral Physics 25Vx infrasound sensor } \\
\text { Guralp CMG-3T three-component broadband seismometer } \\
\text { Guralp CMG-40T three-component broadband seismometer } \\
\text { Guralp CMG-5T three-component broadband seismometer } \\
\text { Guralp CMG-6TD three-component broadband seismometer } \\
\text { Guralp CMG-3ESP three-component broadband seismometer } \\
\text { three-component broadband seismometer } \\
\text { Mark Products L4 or L4-3D single-component short-period seismometer } \\
\text { Mark Products L22 three-component short-period seismometer } \\
\text { MP L28 ocean bottom seismometer } \\
\text { Teledyne Geotech S13 single-component short-period seismometer } \\
\text { Streckeisen STS-2 broadband seismometer } \\
\text { Nanometrics Trillium } 40 \text { three-component broadband seismometer }\end{array}$ \\
\hline
\end{tabular}




\section{Appendix C. Locations (datum NAD27) of the AVO Seismograph Stations in 2012.}

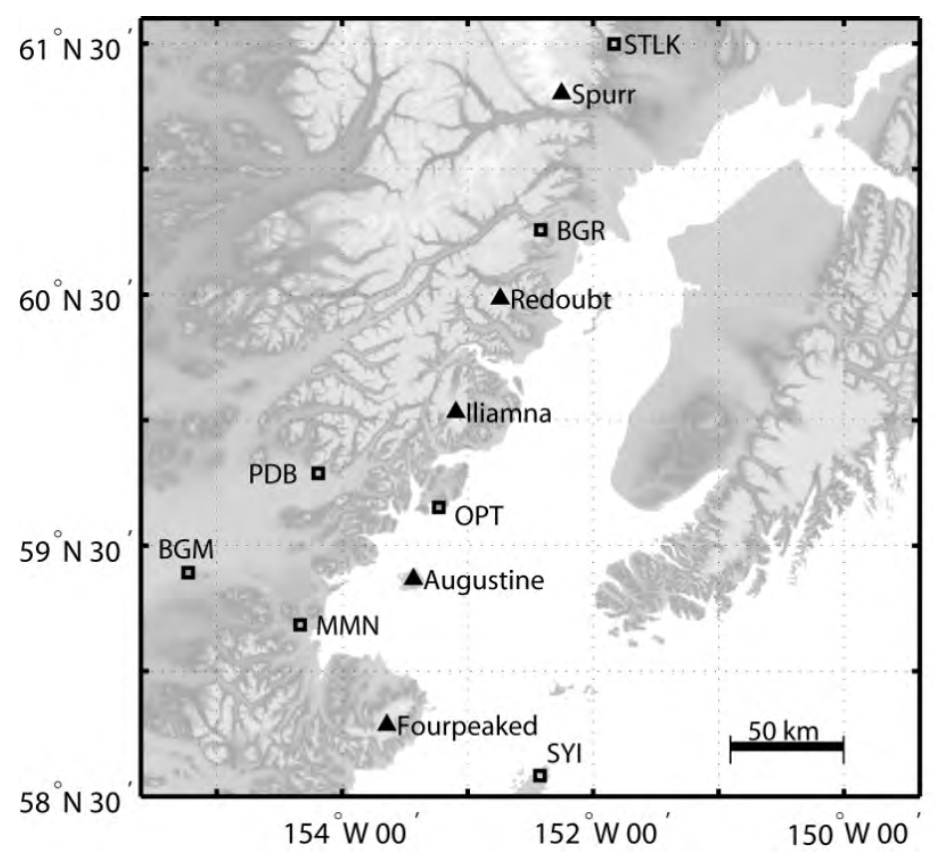

Figure C1. Regional AVO seismograph stations in Cook Inlet in 2012. Permanent stations are shown by open squares. Closed triangles show volcanic centers.

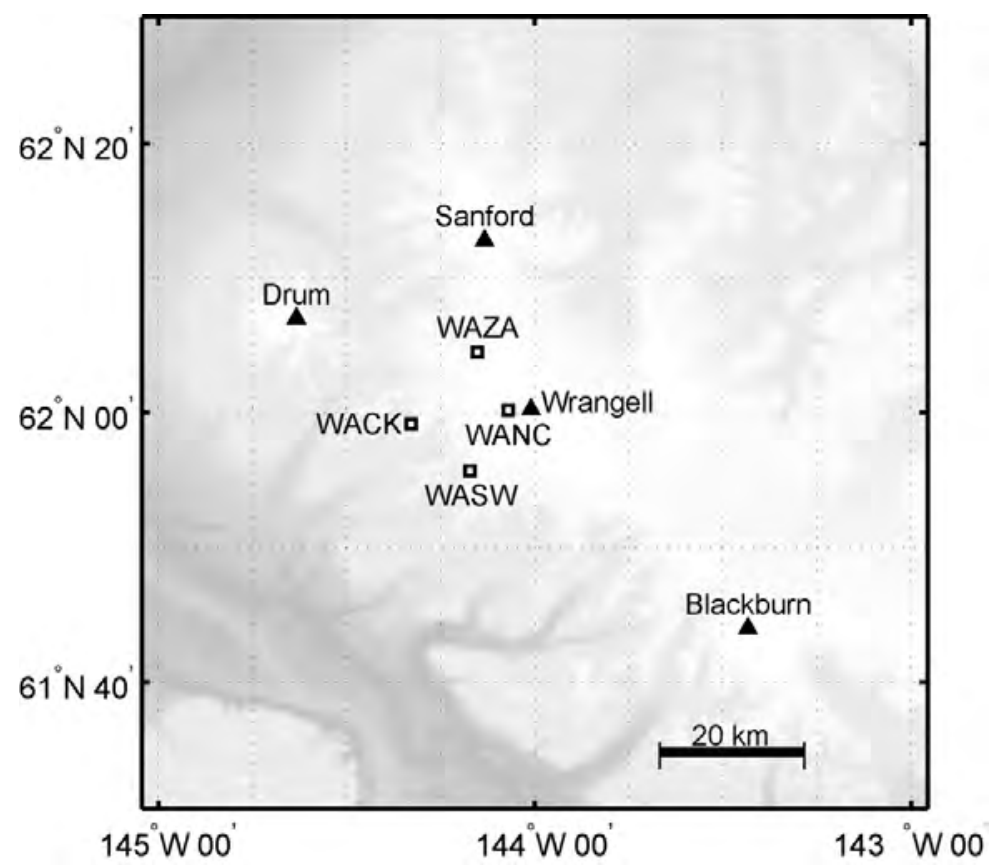

Figure C2. AVO seismograph stations near Mount Wrangell in 2012. Permanent stations are shown by open squares. Closed triangles show volcanic centers. 


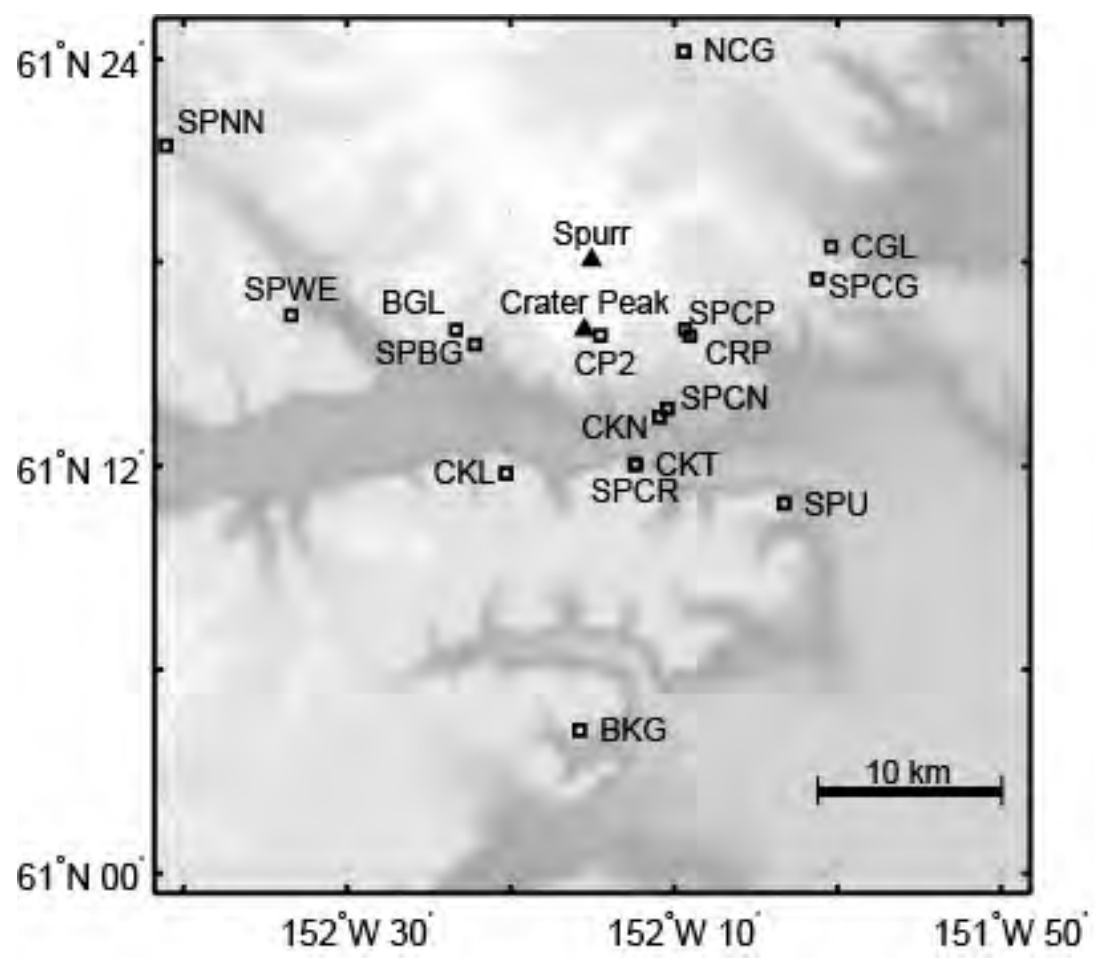

Figure C3. AVO seismograph stations near Mount Spurr in 2012. Permanent stations are shown by open squares. Closed triangles show volcanic centers.

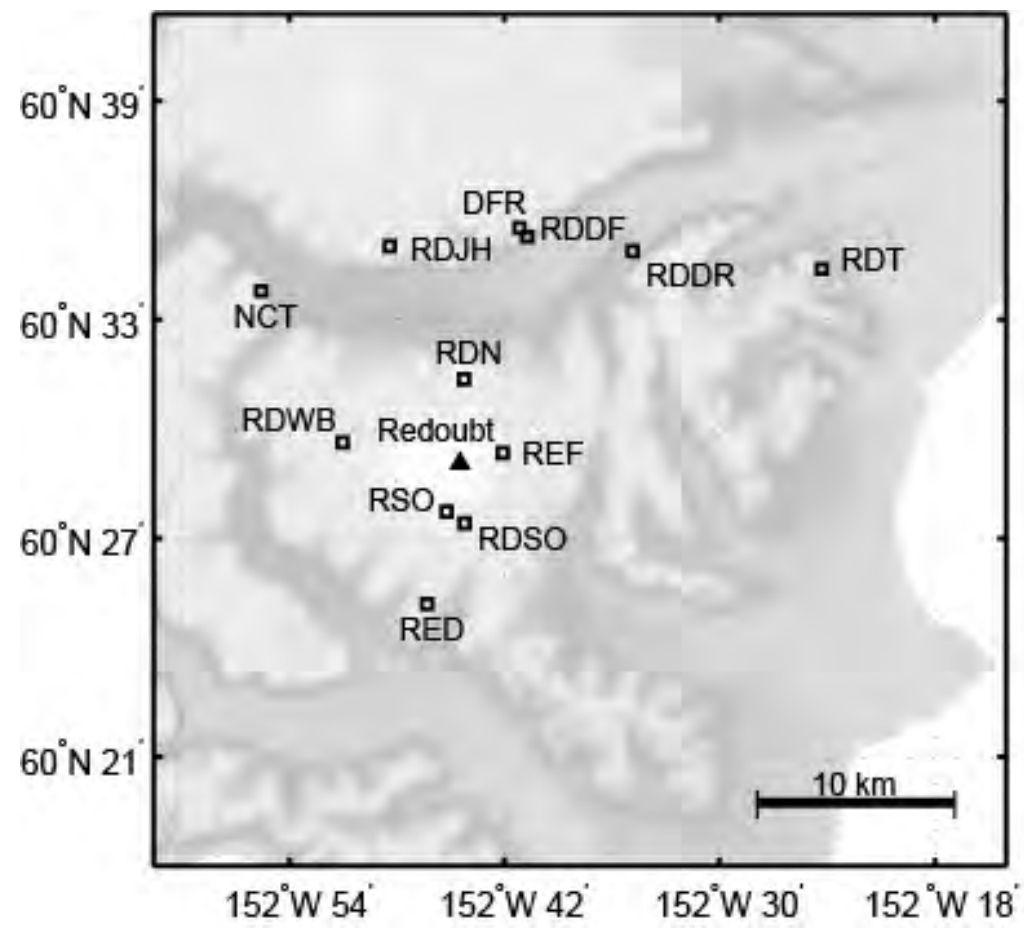

Figure C4. AVO seismograph stations near Redoubt Volcano in 2012. Permanent stations are shown by open squares. Closed triangles show volcanic centers. 


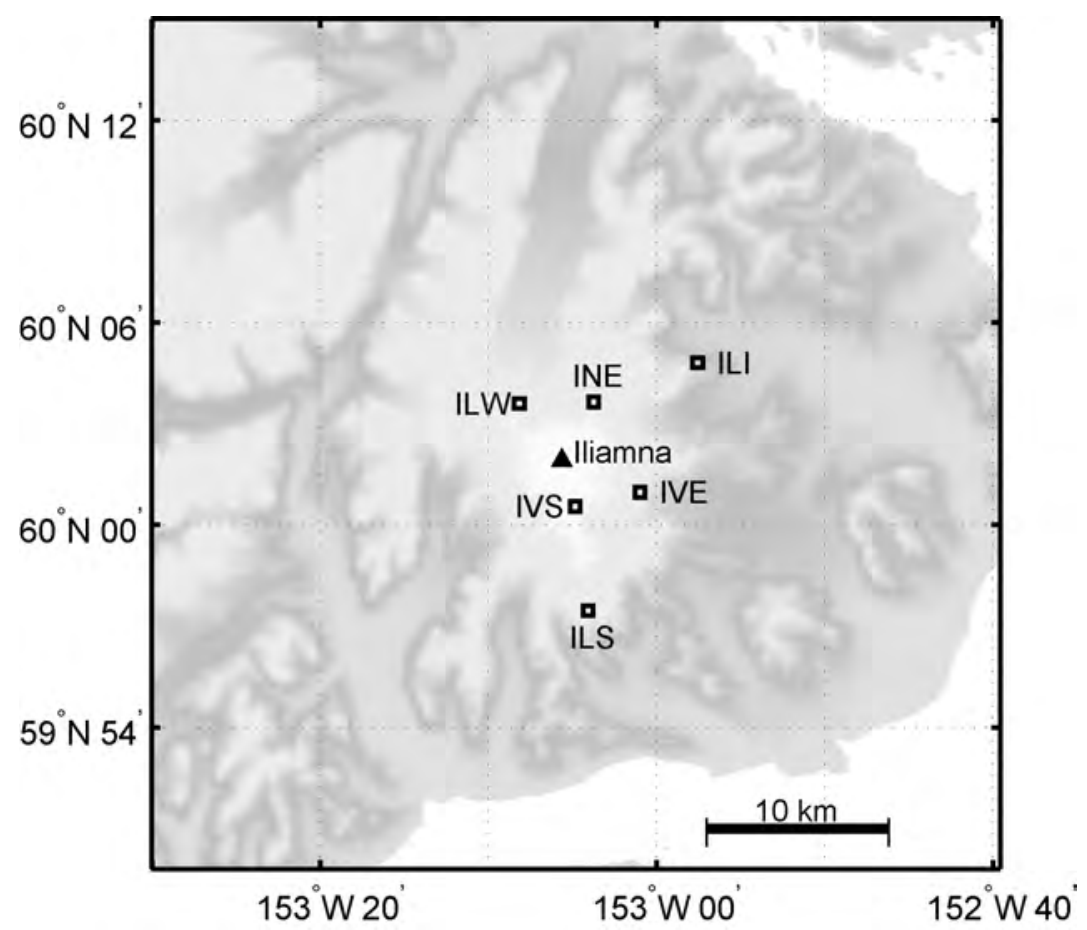

Figure C5. AVO seismograph stations near lliamna Volcano in 2012. Permanent stations are shown by open squares. Closed triangles show volcanic centers.

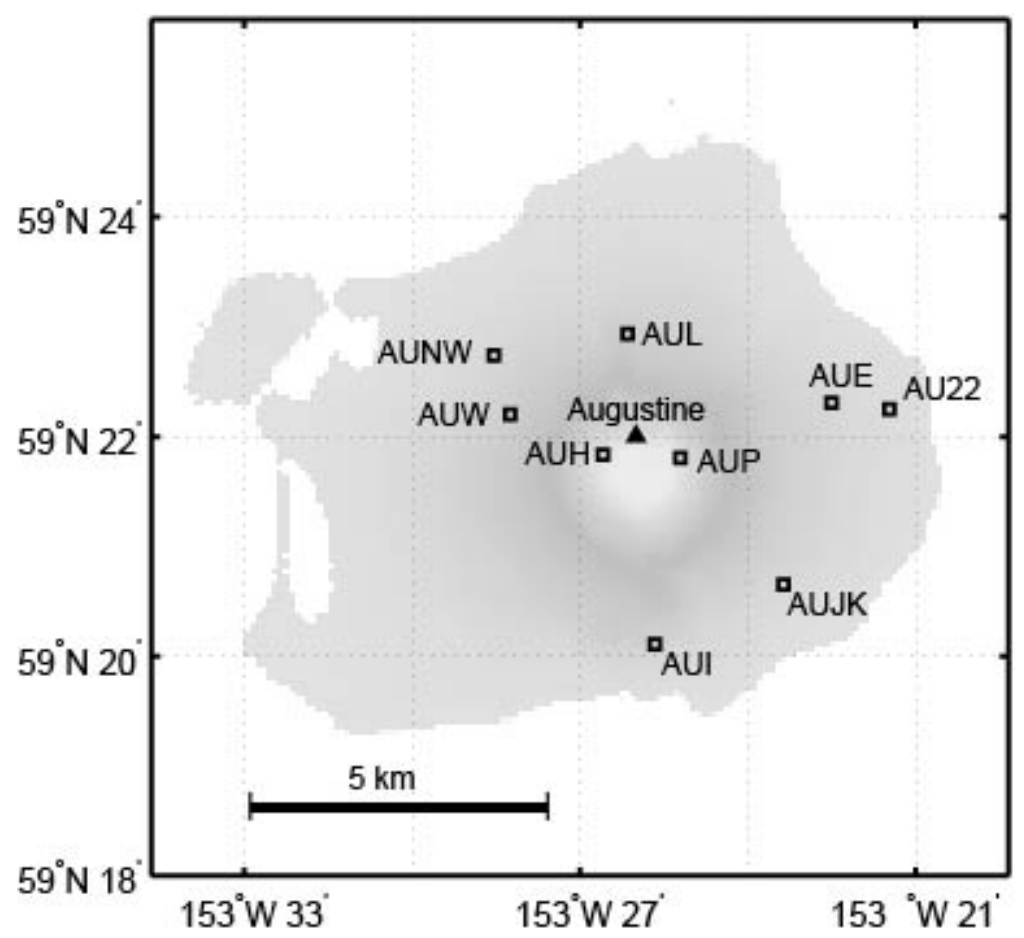

Figure C6. AVO seismograph stations near Augustine Volcano in 2012. Permanent stations are shown by open squares. Closed triangles show volcanic centers. 


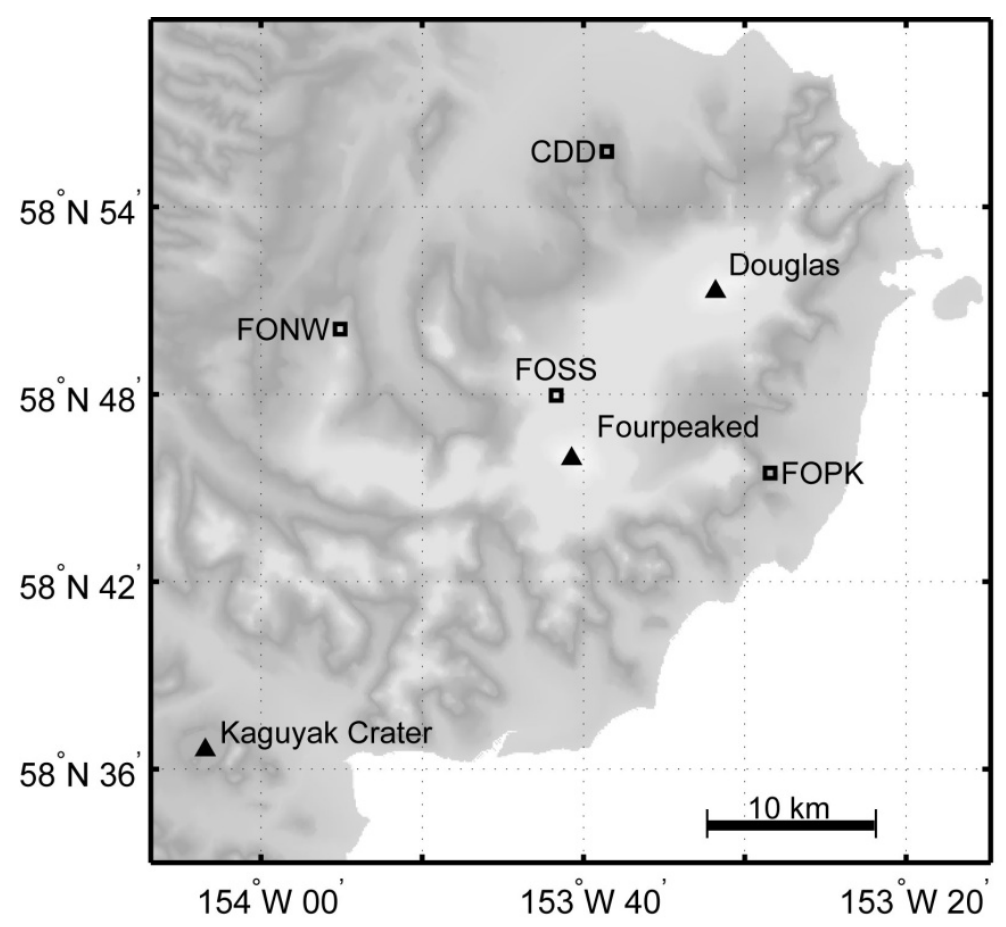

Figure C7. AVO seismograph stations near Fourpeaked Mountain in 2012. Permanent stations are shown by open squares. Closed triangles show volcanic centers.

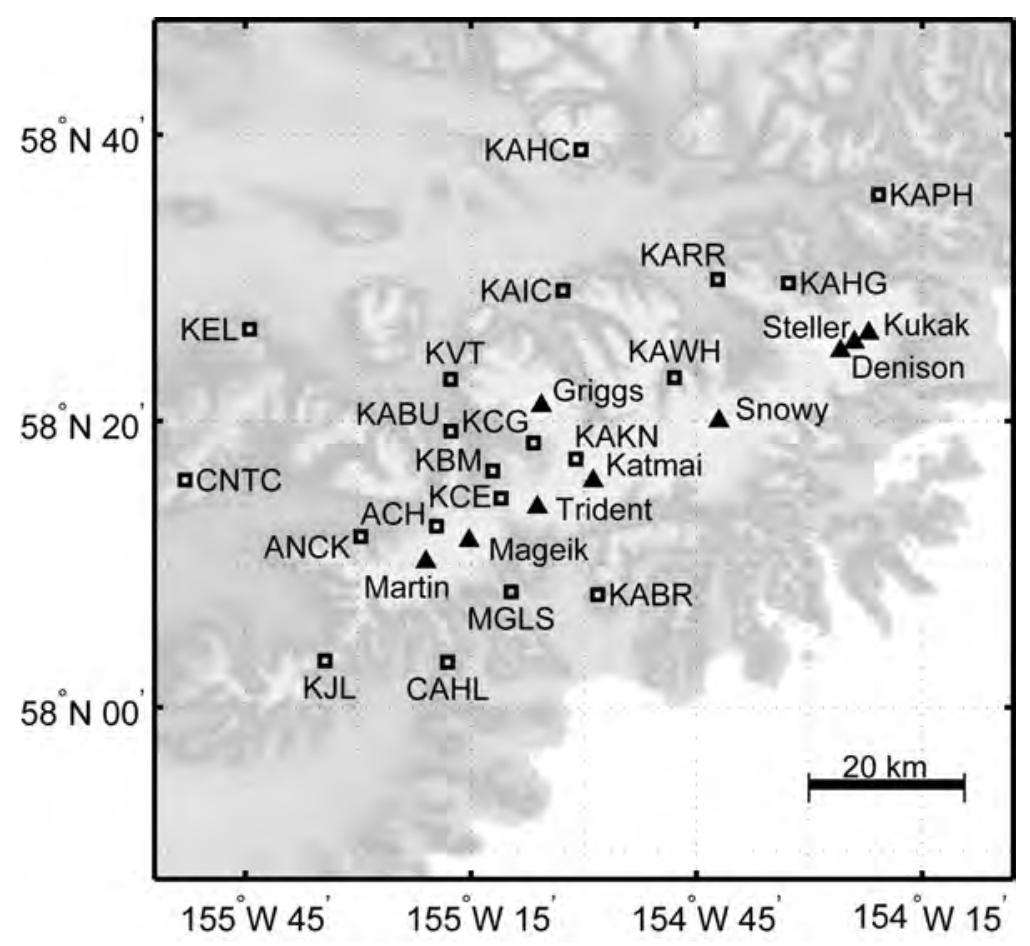

Figure C8. AVO seismograph stations near the Katmai volcanic cluster in 2012. Permanent stations are shown by open squares. Closed triangles show volcanic centers. 


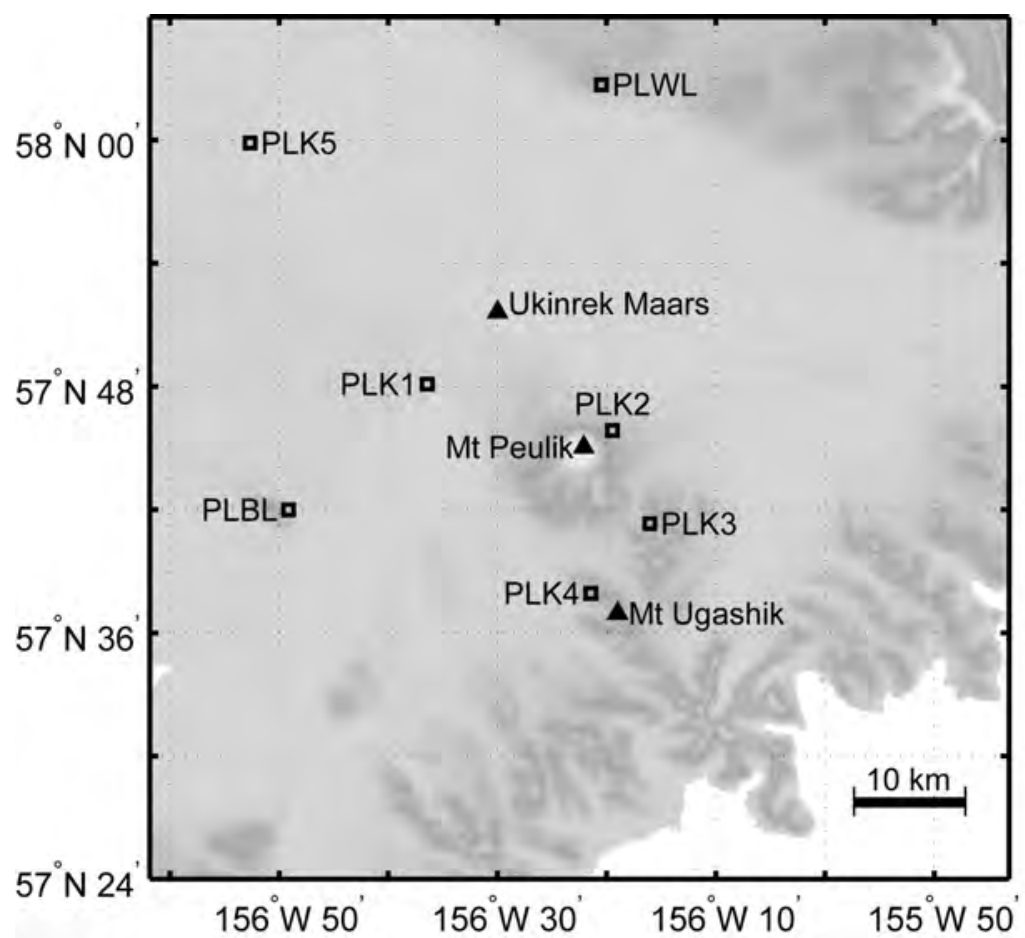

Figure C9. AVO seismograph stations near the Mount Peulik in 2012. Permanent stations are shown by open squares. Closed triangles show volcanic centers.

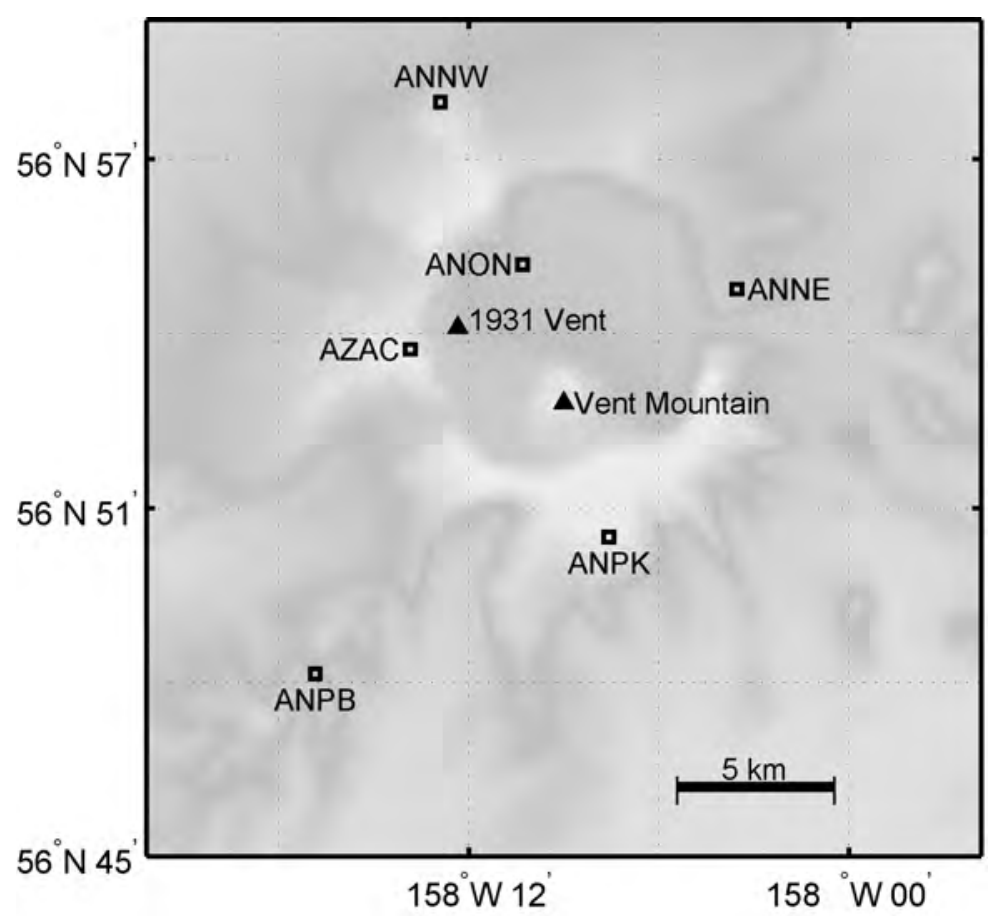

Figure C10. AVO seismograph stations near Aniakchak Crater in 2012. Permanent stations are shown by open squares. Closed triangles show volcanic centers. 


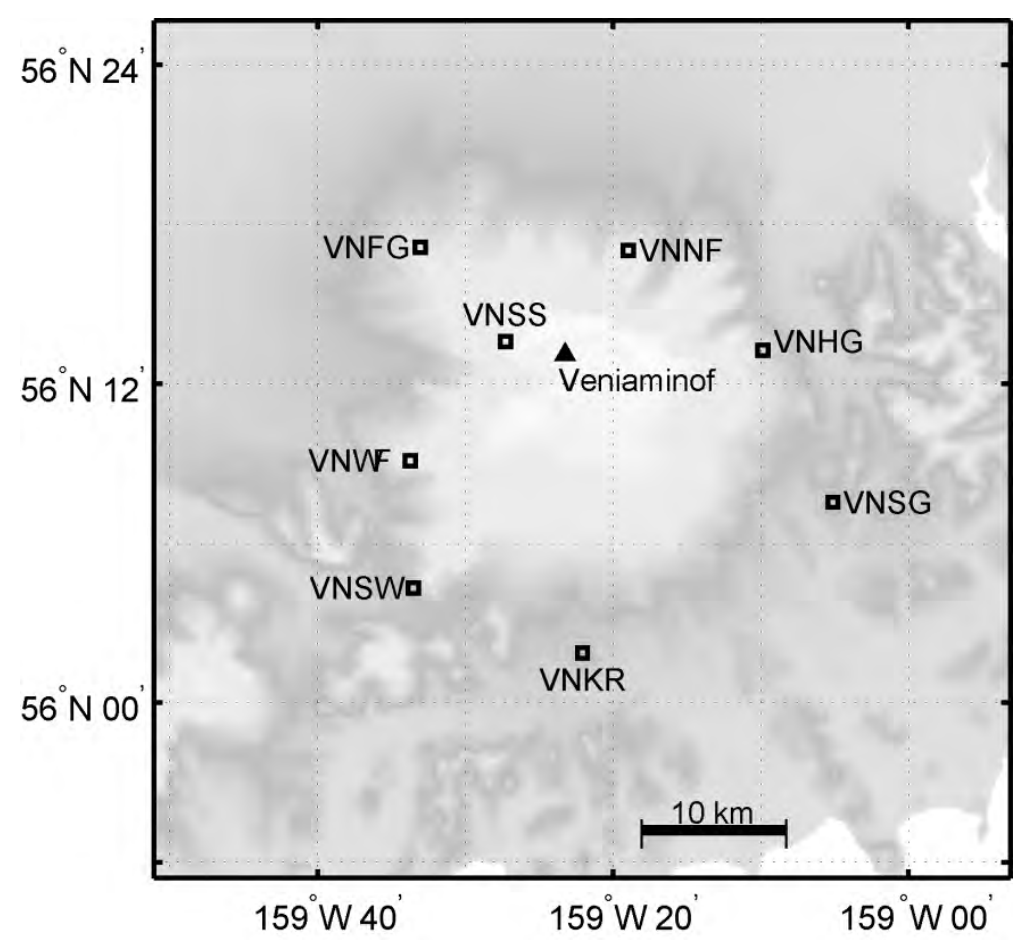

Figure C11. AVO seismograph stations near Mount Veniaminof in 2012. Seismograph station BPBC is not shown and is located $70 \mathrm{~km}$ northeast of Mount Veniaminof. Permanent stations are shown by open squares. Closed triangles show volcanic centers.

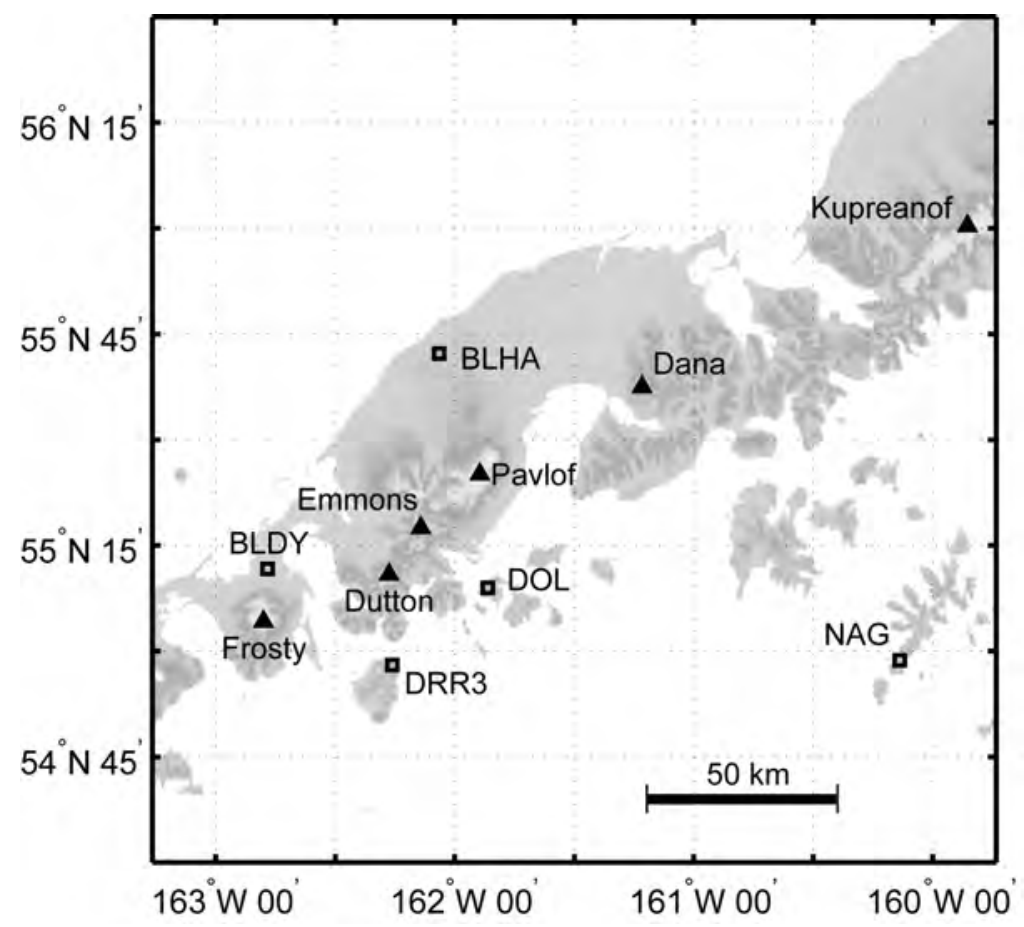

Figure C12. Regional AVO seismograph stations on the Alaska Peninsula in 2012. Permanent stations are shown by open squares. Closed triangles show volcanic centers. 


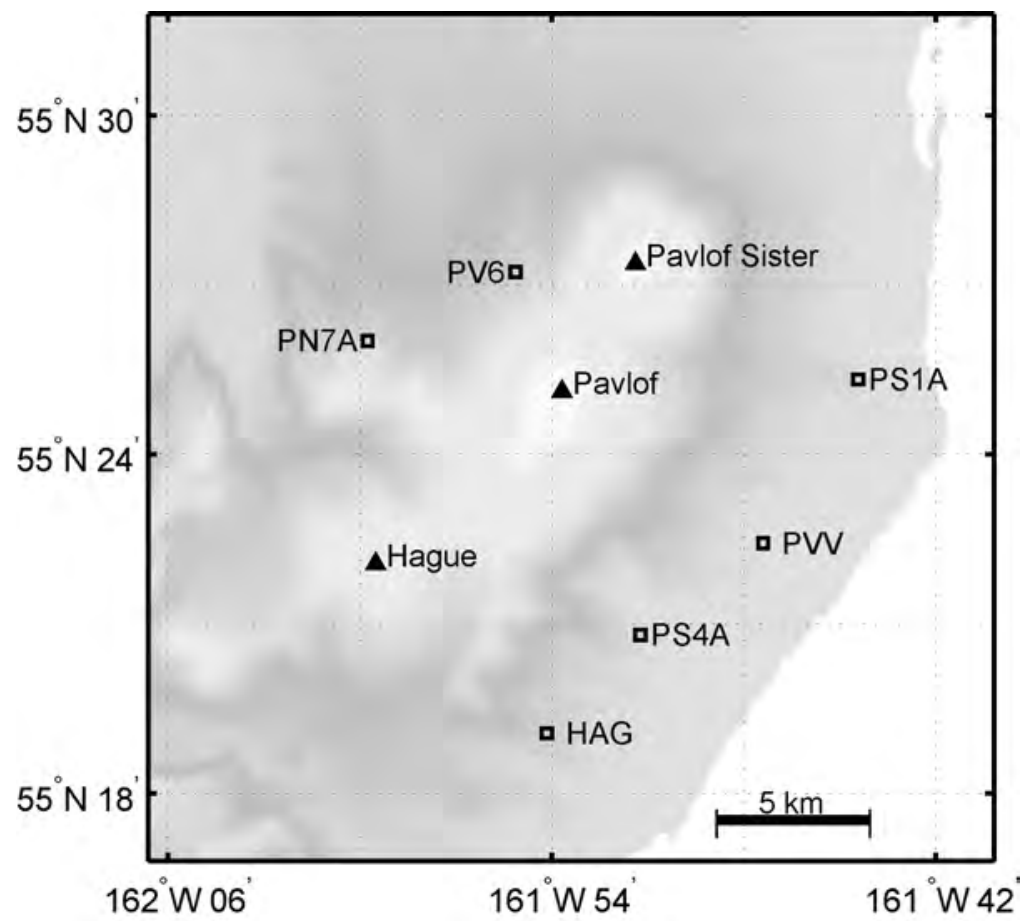

Figure C13. AVO seismograph stations near Pavlof Volcano in 2012. Permanent stations are shown by open squares. Closed triangles show volcanic centers.

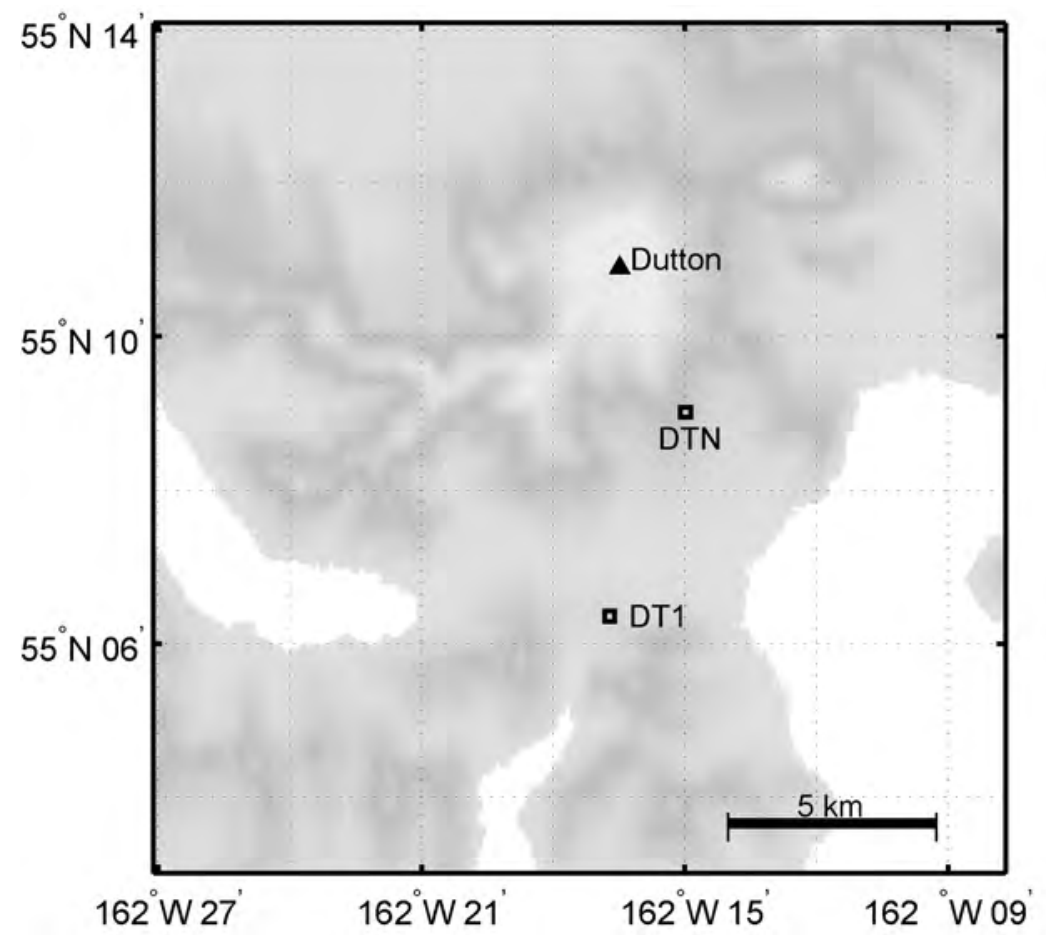

Figure C14. AVO seismograph stations near Mount Dutton in 2012. Permanent stations are shown by open squares. Closed triangles show volcanic centers. 


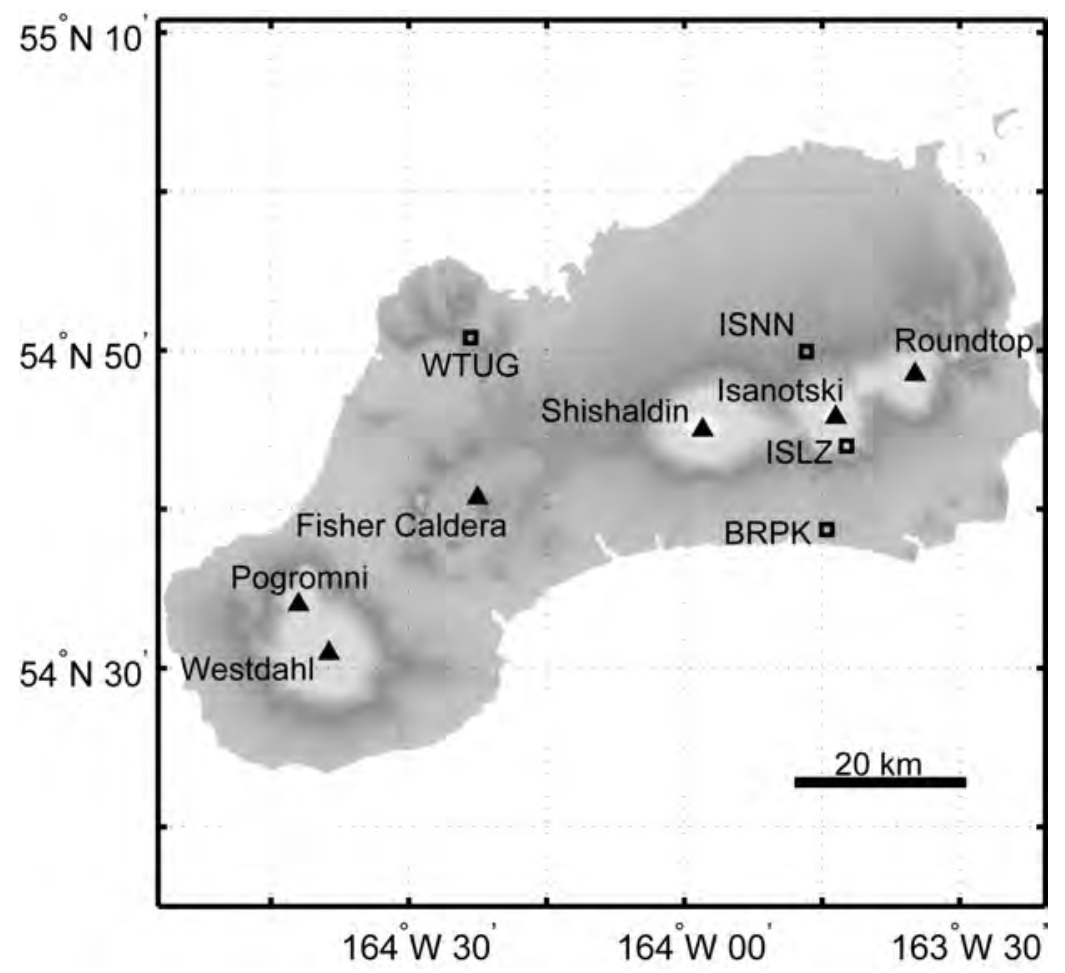

Figure C15. Regional AVO seismograph stations on Unimak Island in 2012. Permanent stations are shown by open squares. Closed triangles show volcanic centers.

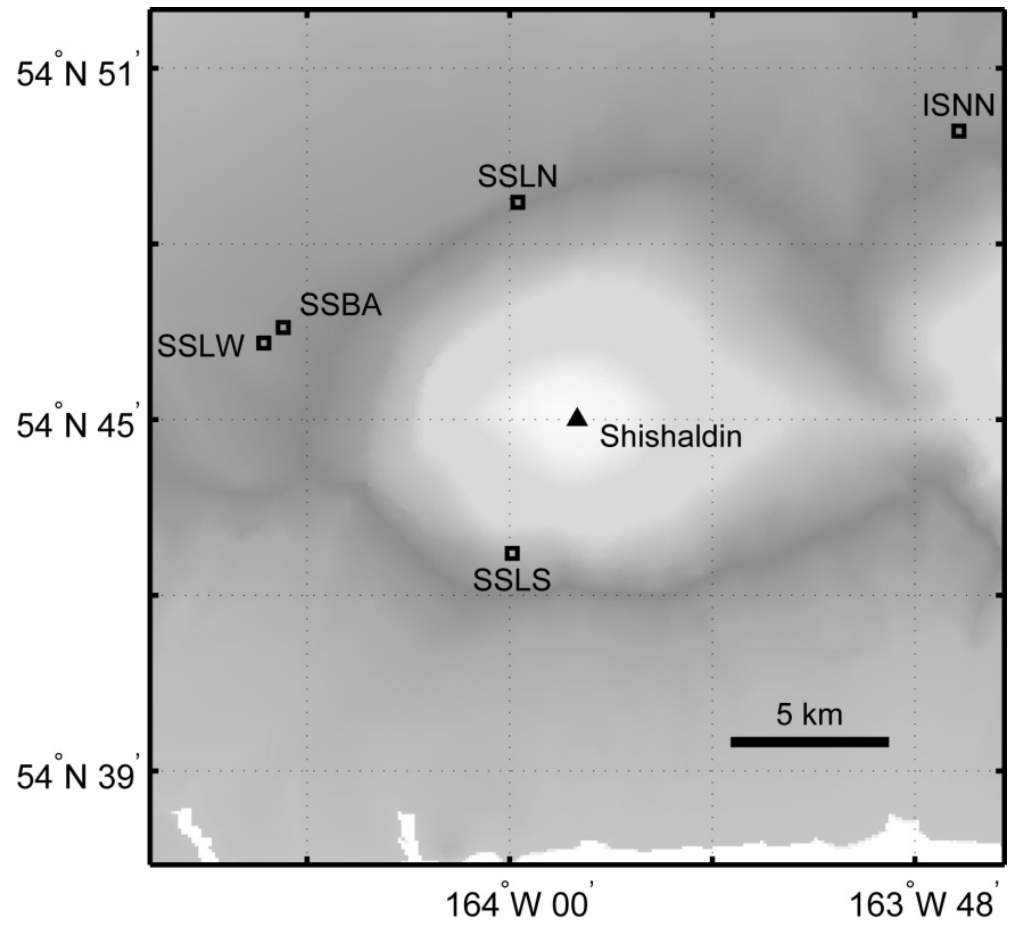

Figure C16. AVO seismograph stations near Shishaldin Volcano in 2012. Permanent stations are shown by open squares. Closed triangles show volcanic centers. 


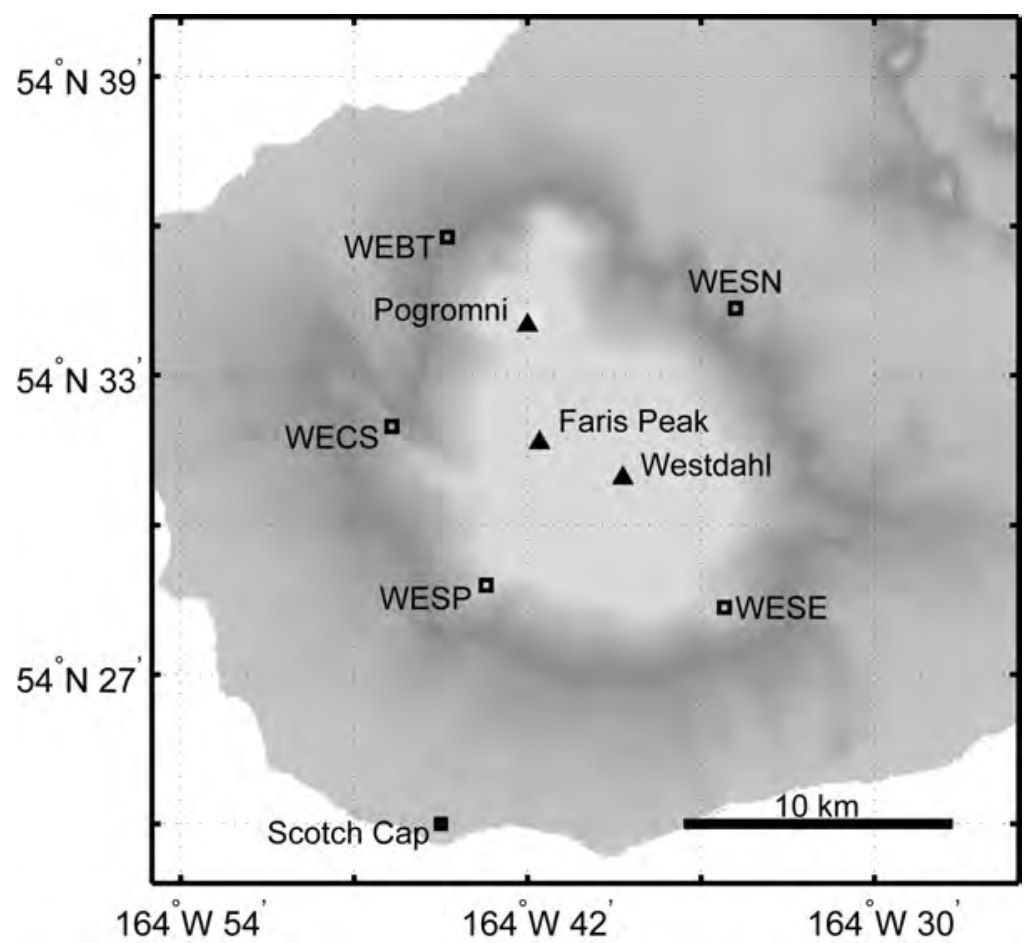

Figure C17. AVO seismograph stations near Westdahl Peak in 2012. Permanent stations are shown by open squares. Closed triangles show volcanic centers. Solid squares indicate points of interest.

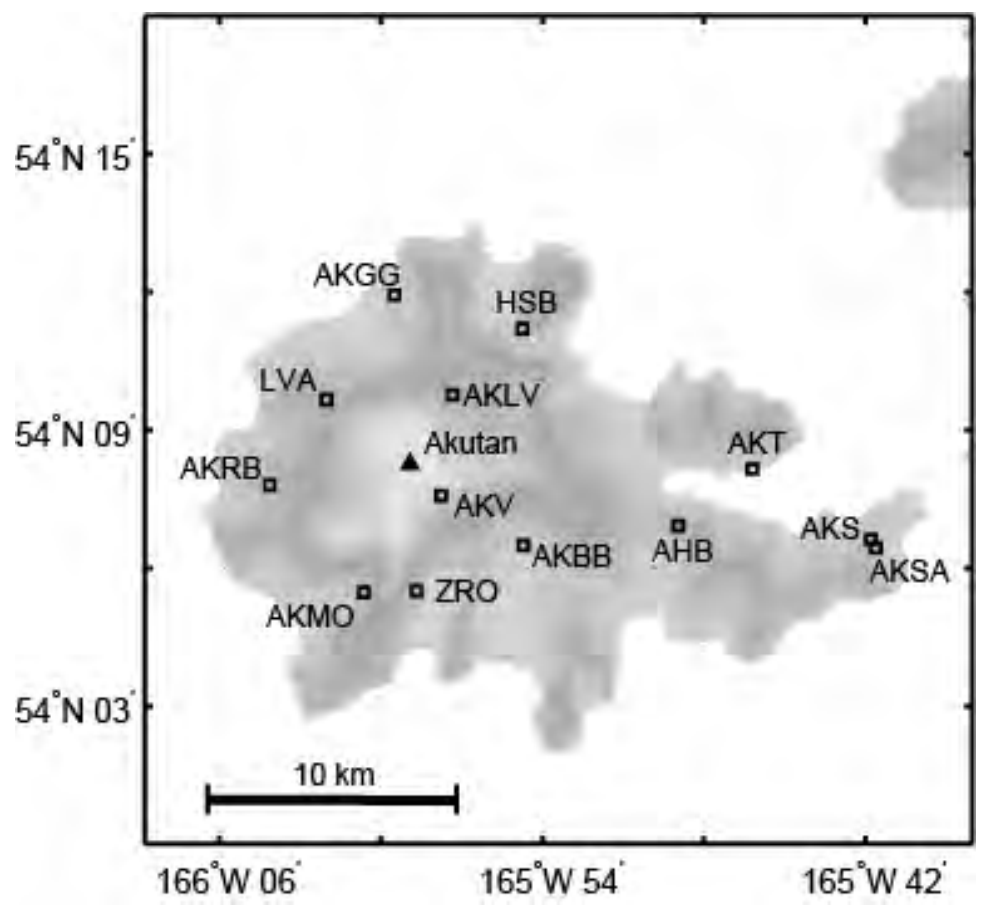

Figure C18. AVO seismograph stations near Akutan Peak in 2012. Permanent stations are shown by open squares. Closed triangles show volcanic centers. 


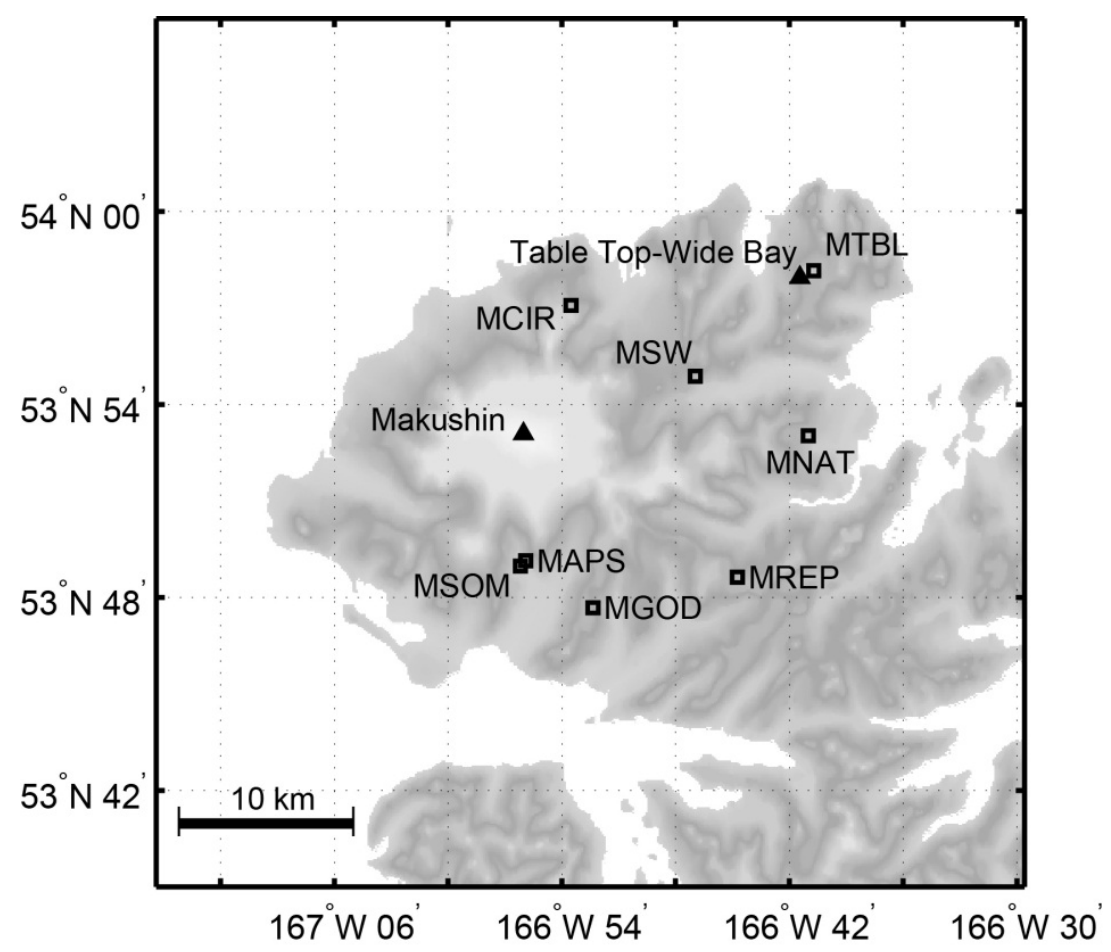

Figure C19. AVO seismograph stations near Makushin Volcano in 2012. Permanent stations are shown by open squares. Closed triangles show volcanic centers.

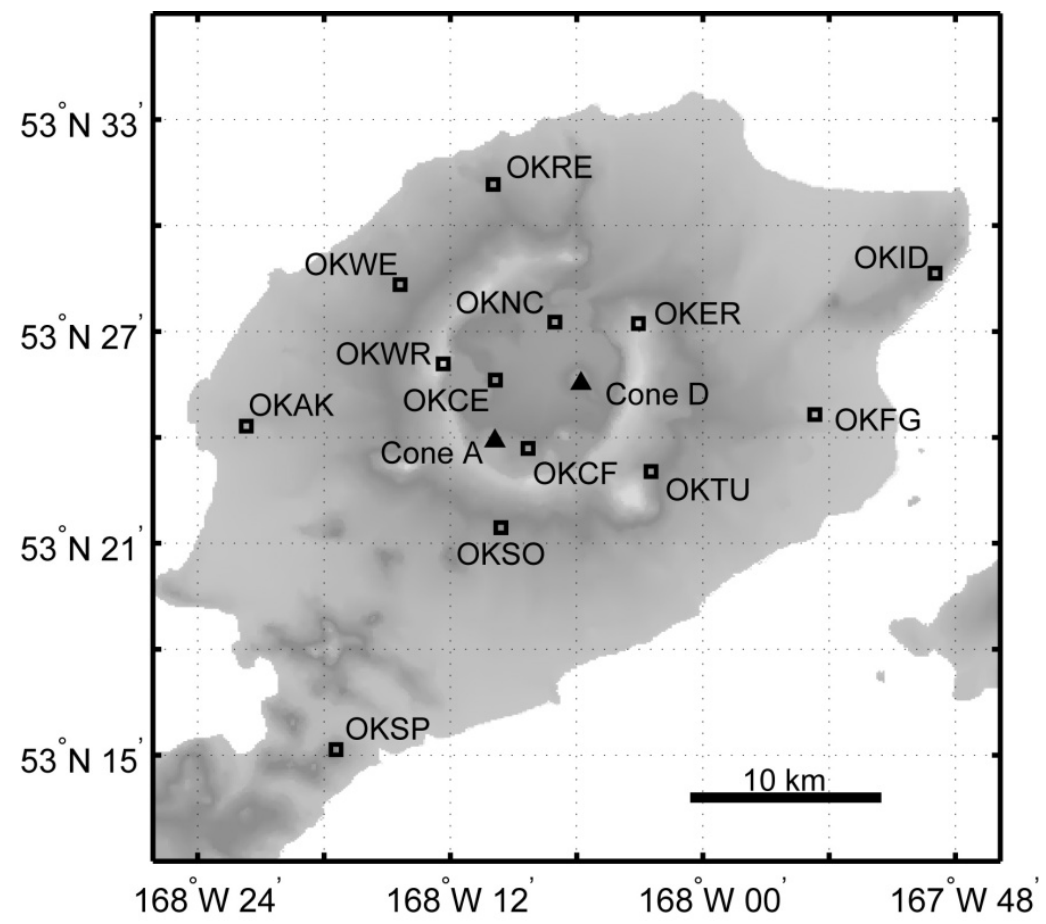

Figure C20. AVO seismograph stations near Okmok Volcano in 2012. Permanent stations are shown by open squares. Closed triangles show volcanic centers. 


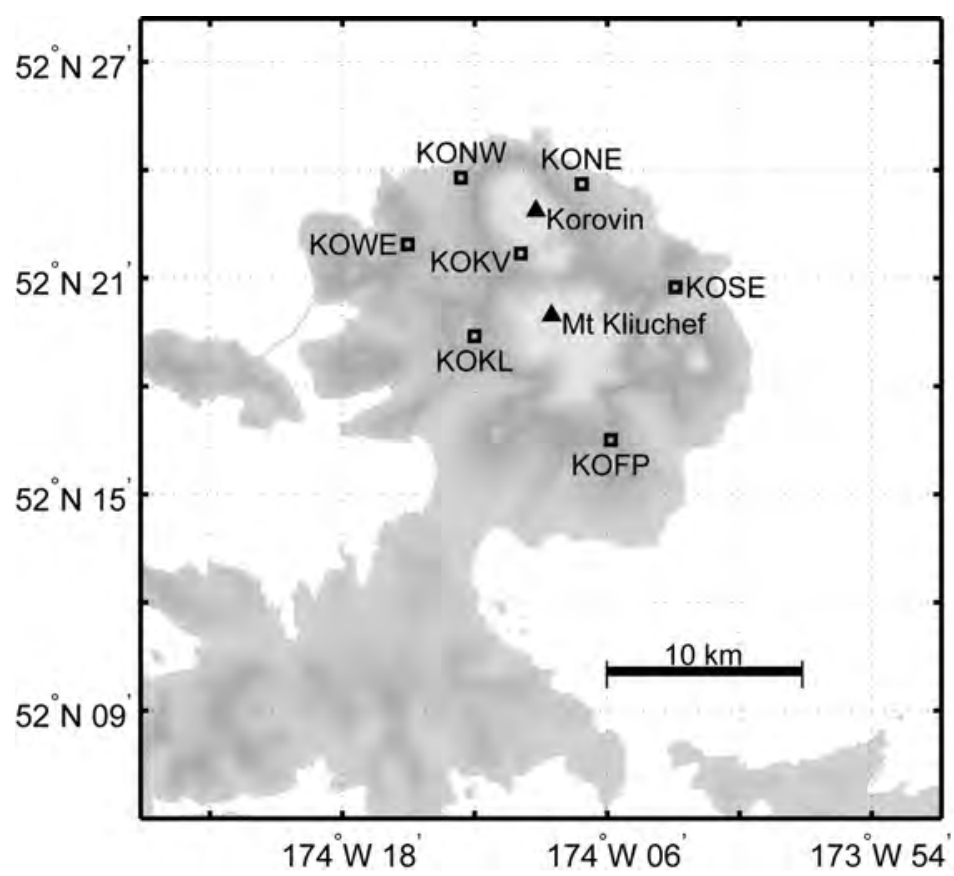

Figure C21. AVO seismograph stations on Atka Island in 2012. Permanent stations are shown by open squares. Closed triangles show volcanic centers.

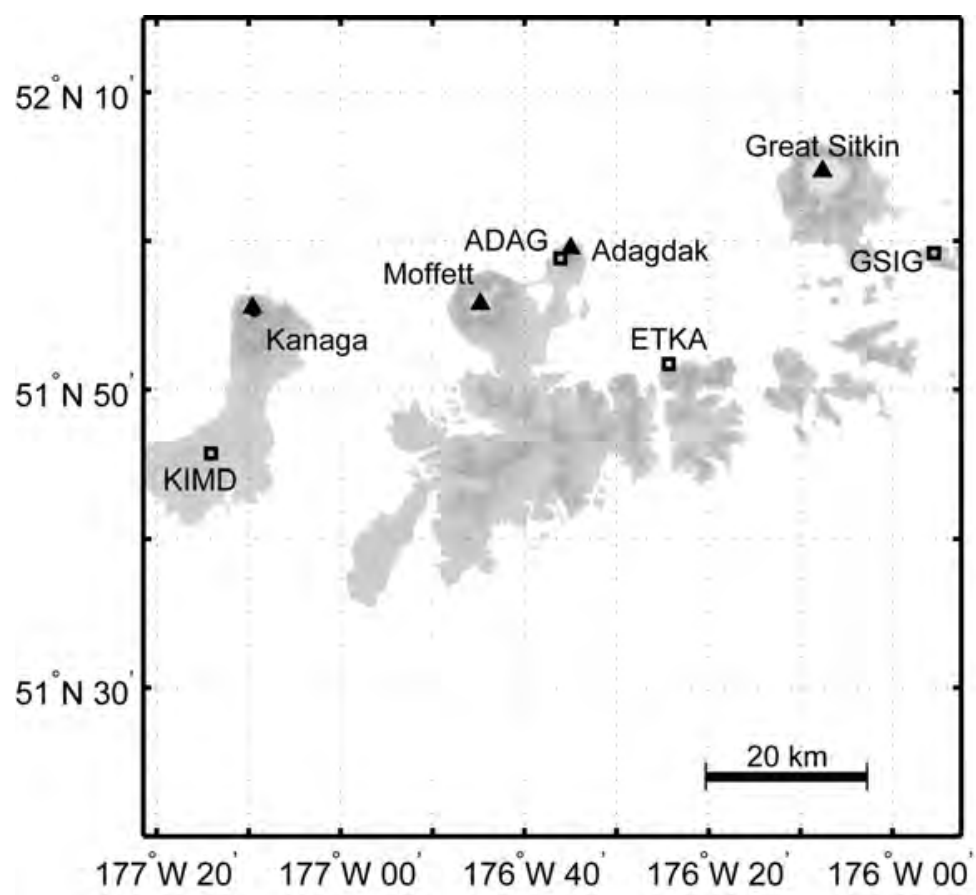

Figure C22. Regional AVO seismograph stations around Adak Island in 2012. Permanent stations are shown by open squares. Closed triangles show volcanic centers. 


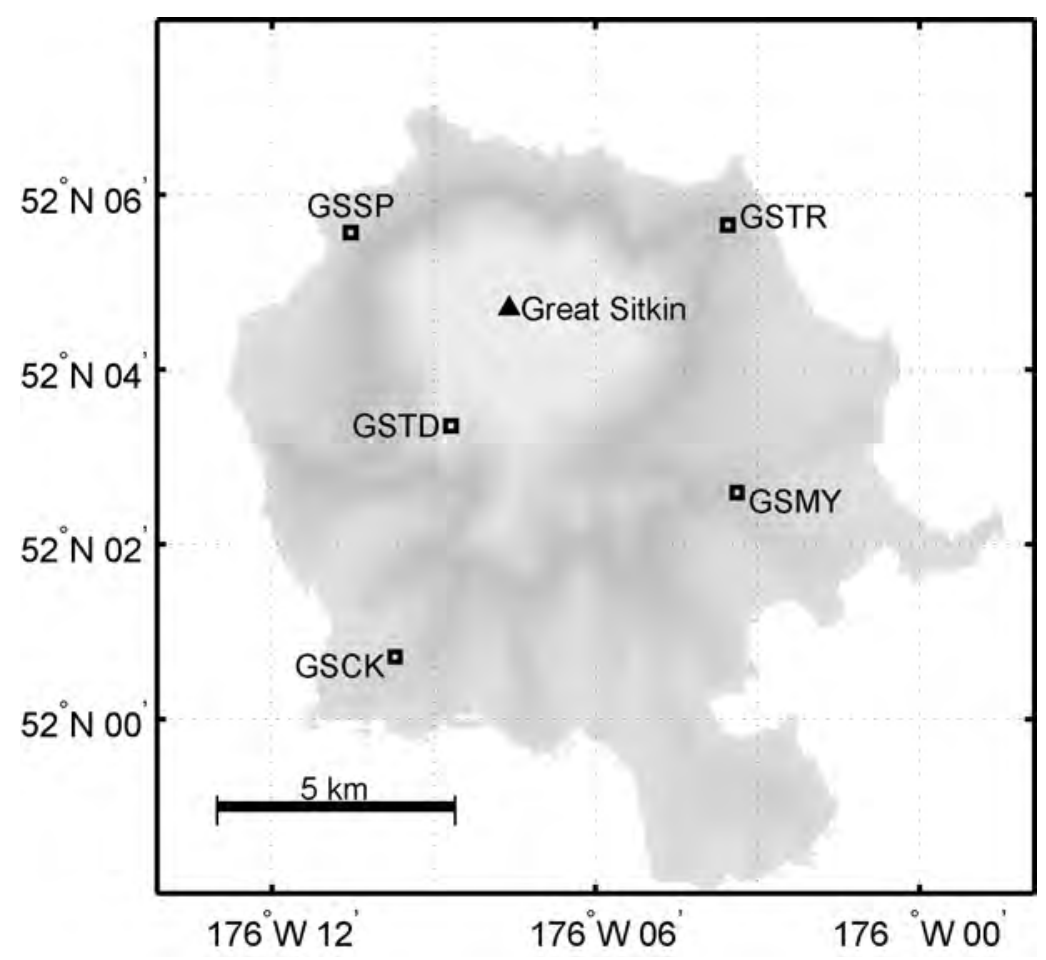

Figure C23. AVO seismograph stations near Great Sitkin Volcano in 2012. Permanent stations are shown by open squares. Closed triangles show volcanic centers.

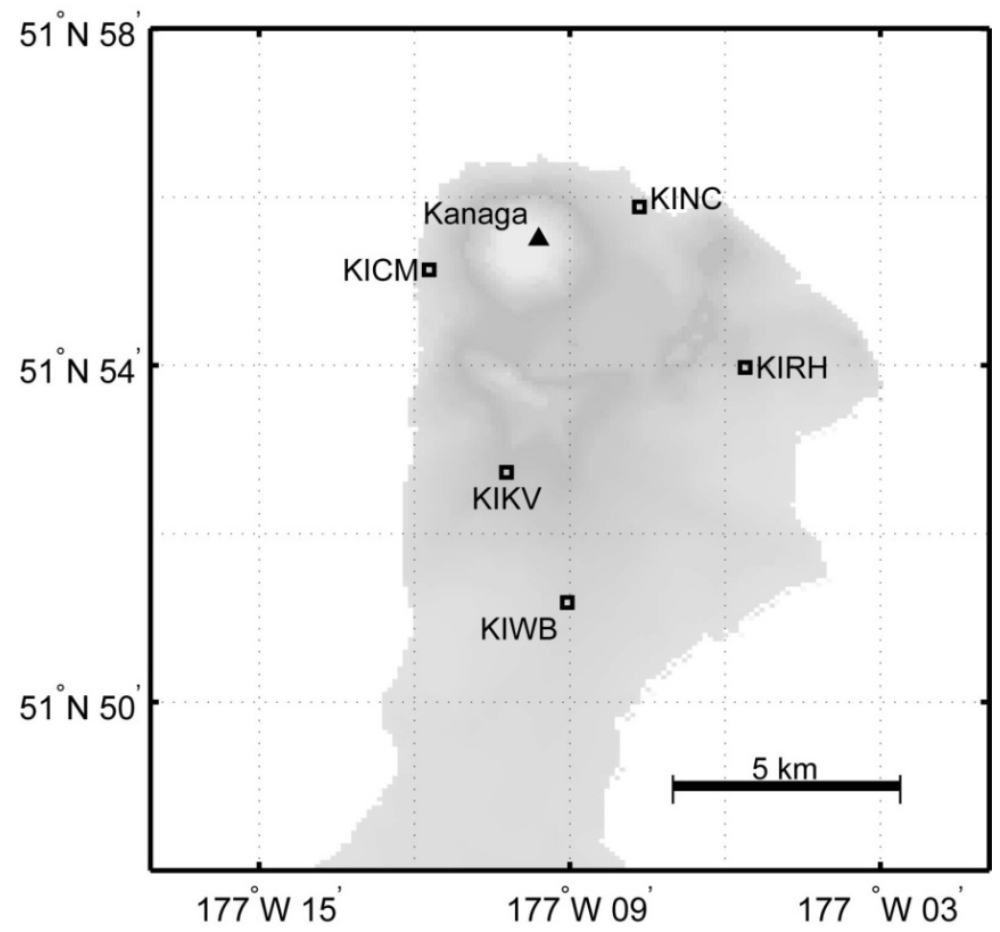

Figure C24. AVO seismograph stations near Kanaga Volcano in 2012. Permanent stations are shown by open squares. Closed triangles show volcanic centers. 


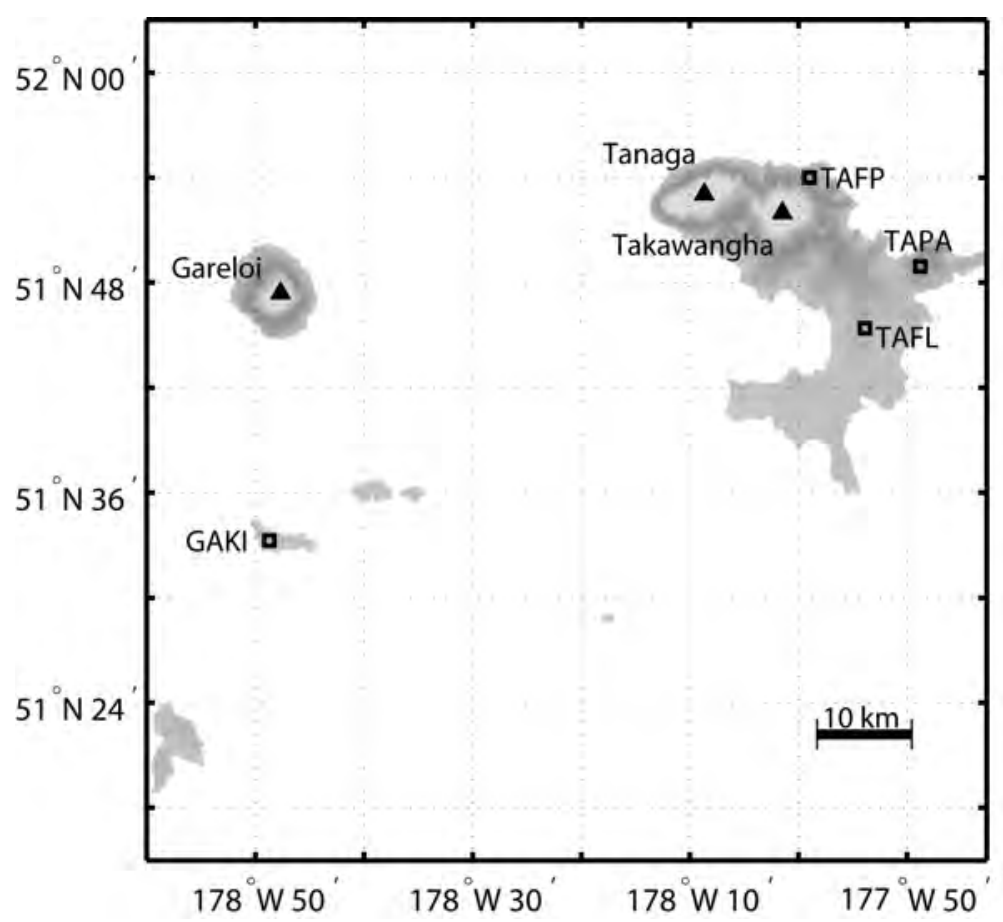

Figure C25. Regional AVO seismograph stations around Tanaga Volcano and Mount Gareloi in 2012. Permanent stations are shown by open squares. Closed triangles show volcanic centers.

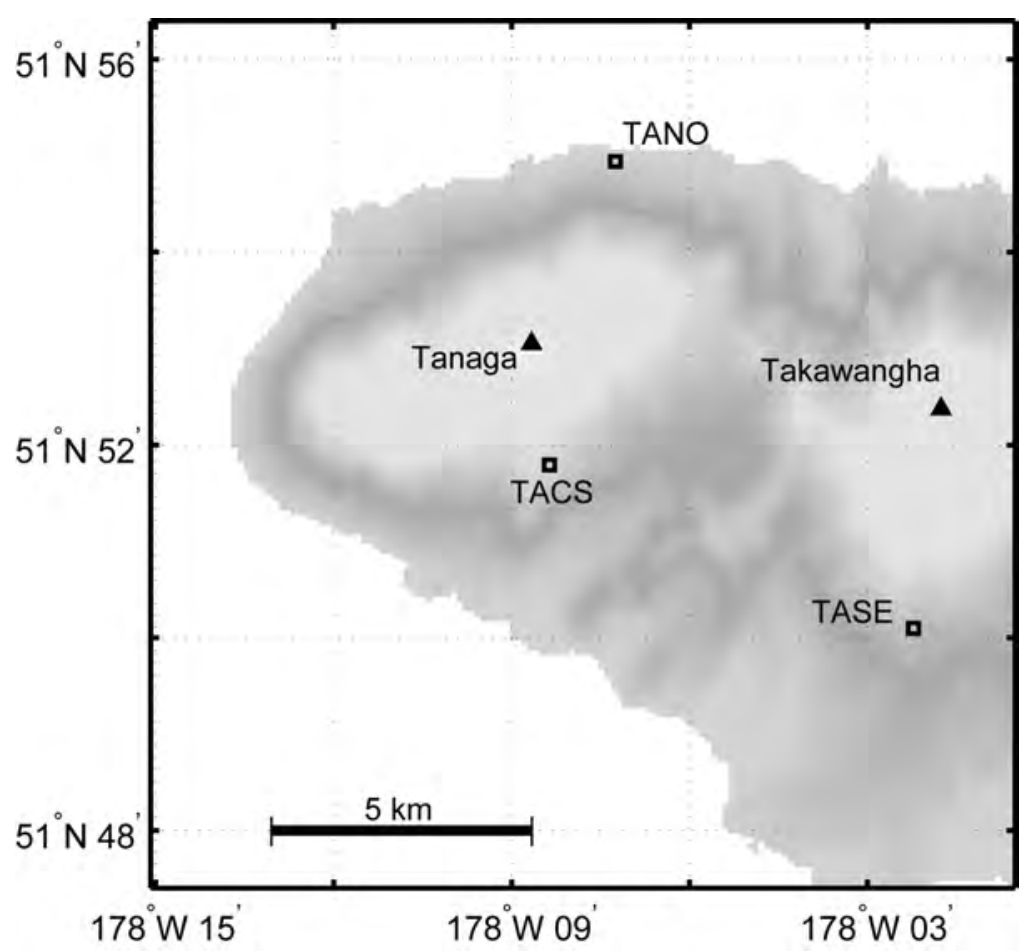

Figure C26. AVO seismograph stations near Tanaga Volcano in 2012. Permanent stations are shown by open squares. Closed triangles show volcanic centers. 


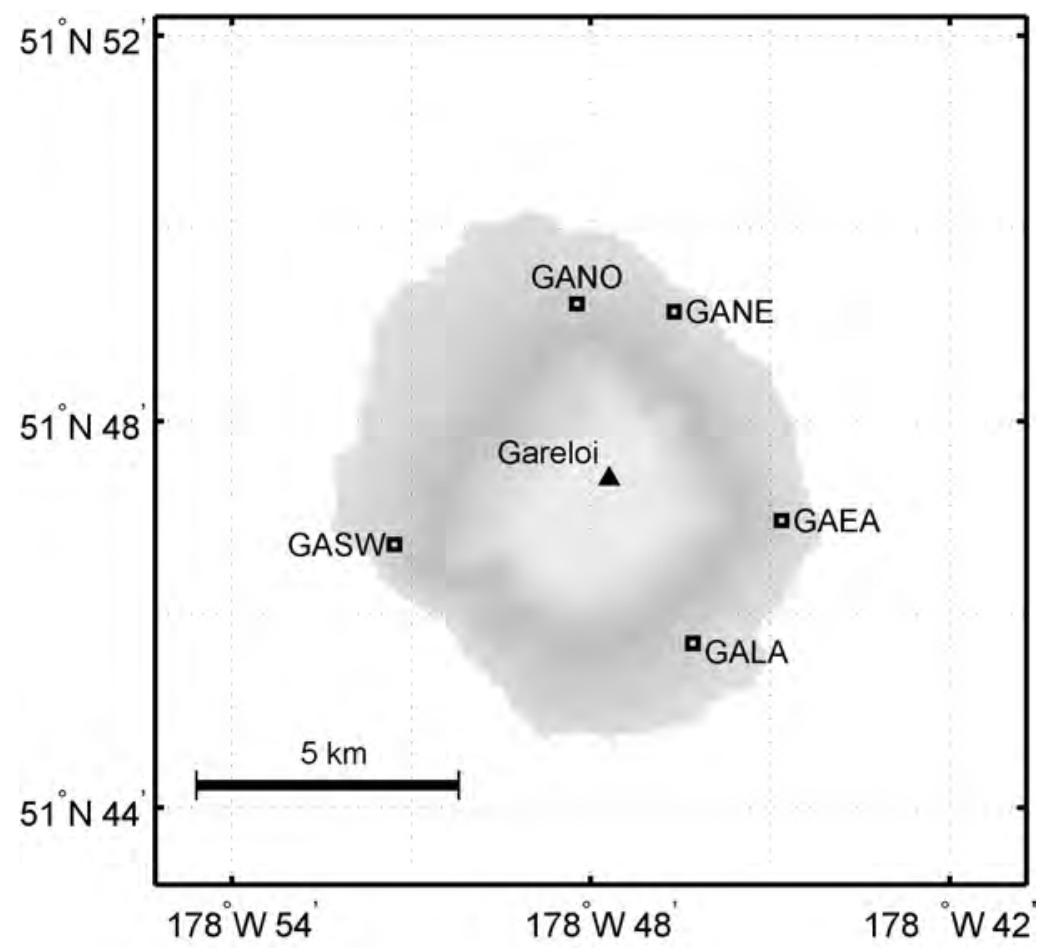

Figure C27. AVO seismograph stations near Mount Gareloi in 2012. Permanent stations are shown by open squares. Closed triangles show volcanic centers.

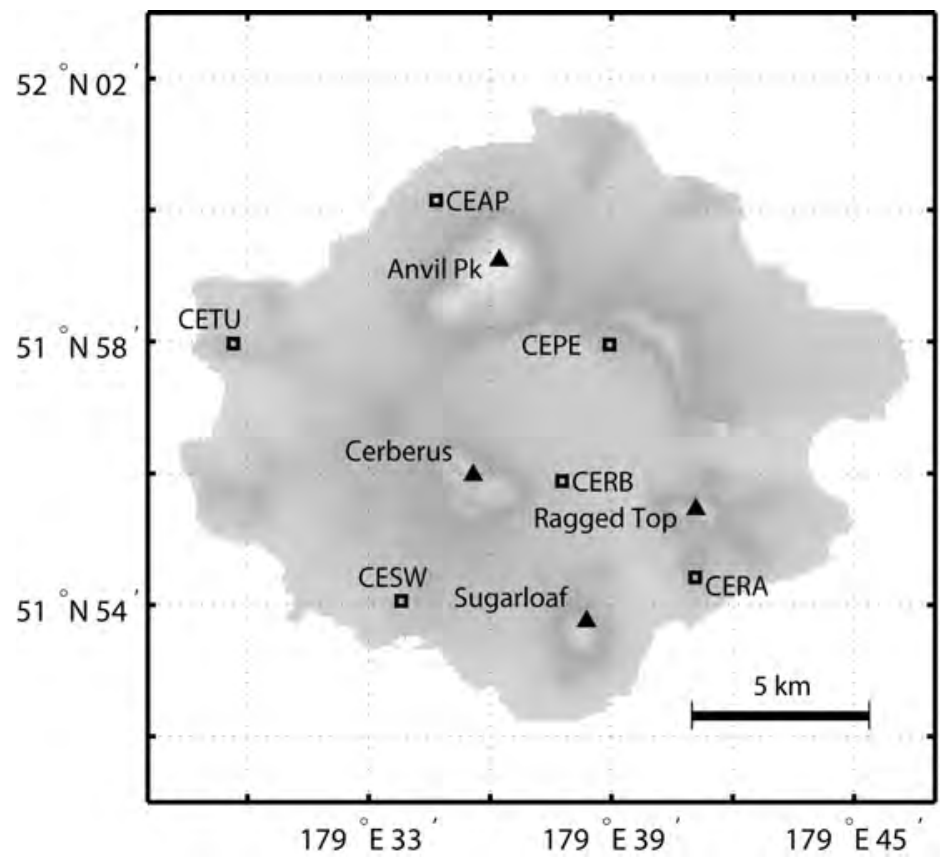

Figure C28. AVO seismograph stations on Semisopochnoi Island in 2012. Seismograph station AMKA is not shown and is located $65 \mathrm{~km}$ south-southwest of Mount Cerberus. Permanent stations are shown by open squares. Closed triangles show volcanic centers. 


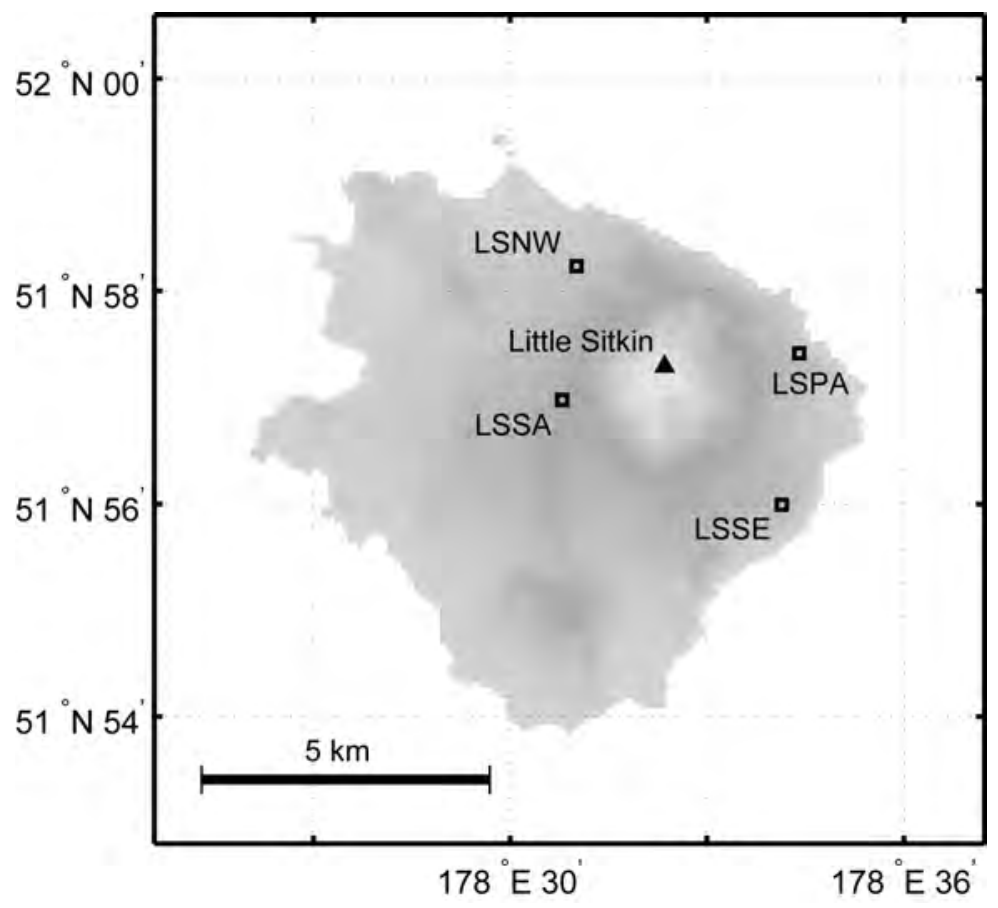

Figure C29. AVO seismograph stations on Little Sitkin Island in 2012. Permanent stations are shown by open squares. Closed triangles show volcanic centers. 
64 Catalog of Earthquake Hypocenters at Alaskan Volcanoes: January 1 through December 31, 2012

This page left intentionally blank 


\section{Appendix D. Operational Status for AVO Stations in 2012.}

The operational status of the AVO seismic stations for 2012 is shown utilizing IRIS's Gap/Overlap Analysis Tool, or GOAT (Stromme, 2000). GOAT is a Web-based tool associated with SeismiQuery which graphically displays gaps, overlaps, and continuous time spans of the time series data in the DMC's database.

GOAT displays a color-coded graph depicting gaps in red, and continuous data in green. A summary of the station availability is below. Stations that are not available through IRIS and subsequently not on the figure are shown in the table in italics.

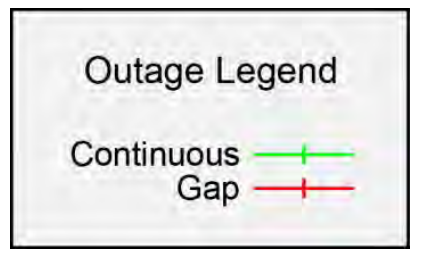

\begin{tabular}{|c|c|}
\hline $\begin{array}{c}\text { Data } \\
\text { Availability }\end{array}$ & Stations \\
\hline $100 \%$ & none \\
\hline $90-99 \%$ & $\begin{array}{l}\text { ACH, ADAG, AHB, AKS, AKV, ANCK, ANNE, ANNW, ANON, ANPB, } \\
\text { ANPK, AUE, AUH, AUL,AUJK, AUNW, AUP, AUW, AZAC, BLDY, } \\
\text { BLHA, BPBC, CAHL, CDD, CNTC, ETKA, FOPK, FOSS, GALA, GSMY, } \\
\text { GSTD, HSB, ILI, ILS, ISNN, 1VE, KABR, KAHC, KAHG, KAIC, KAPH, } \\
\text { KARR, KAWH, KBM, KCE, KGC, KEL, KICM, KIKV, KINC, KIRH, KJL, } \\
\text { KOFP, KOKL, MAPS, OKCE, OKNC, OKSO, RDDF, RED, SSLN, SSLW, } \\
\text { VNFG, VNHG, VNSG, VNSS, WASW, WEBT, WECS, WESN, WESP, } \\
\text { WTUG, ZRO }\end{array}$ \\
\hline $80-89 \%$ & $\begin{array}{l}\text { AKRB, AUI, BGL, BGM, CKL, CKN, CKT, CP2, CRP, DFR, DT1, FONW, } \\
\text { GSCK, ILW, INE, IVS, KOWE, KVT, LVA, MCIR, MGLS, MGOD, MNAT, } \\
\text { MSW, MTBL, PV7A, PV6, RDJH, RDN, RDT, REF, RSO, SPNN, SPU, } \\
\text { SPWE, SSLS, STLK, TAPA }\end{array}$ \\
\hline $70-79 \%$ & $\begin{array}{l}\text { BRPK, DOL, DRR3. DTN, GAKI, GANE, GSTR, HAG, ISLZ, MMN, MREP, } \\
\text { OKAK, OKCF, OKER, OKID, OKRE, OKSP, OKTU, OKWE, OKWR, OPT, } \\
\text { PDB, PLBL, PLK1, PLK2, PLK3, PLK4, PLK5, PLWL, PVV, TAFL, VNWF }\end{array}$ \\
\hline $60-69 \%$ & GAEA, GANO, GASW, GSIG, GSSP, KABU, KIMD, KIWB, PS1A, PS4A \\
\hline $50-59 \%$ & CGL, SPCR \\
\hline $0-49 \%$ & $\begin{array}{l}\text { AKBB, AKGG, AKLV, AKMO, AKT, AMKA, AU22, BGR, BKG, CEAP, } \\
C E P E, C E R A, C E R B, C E S W, C E T U, K A K N, K O K V, K O N E, K O N W, \text { KOSE, } \\
L S N W, L S P A, L S S A, L S S E, M S O M, N C G, N C T, \text { OKFG, RDDR, SPBG, SPCG, } \\
\text { SPCN, SPCP, SSBA, SYI, TACS, TAFP, TANO, TASE, VNKR, VNNF, } \\
\text { VNSW, WACK, WANC, WAZA }\end{array}$ \\
\hline
\end{tabular}




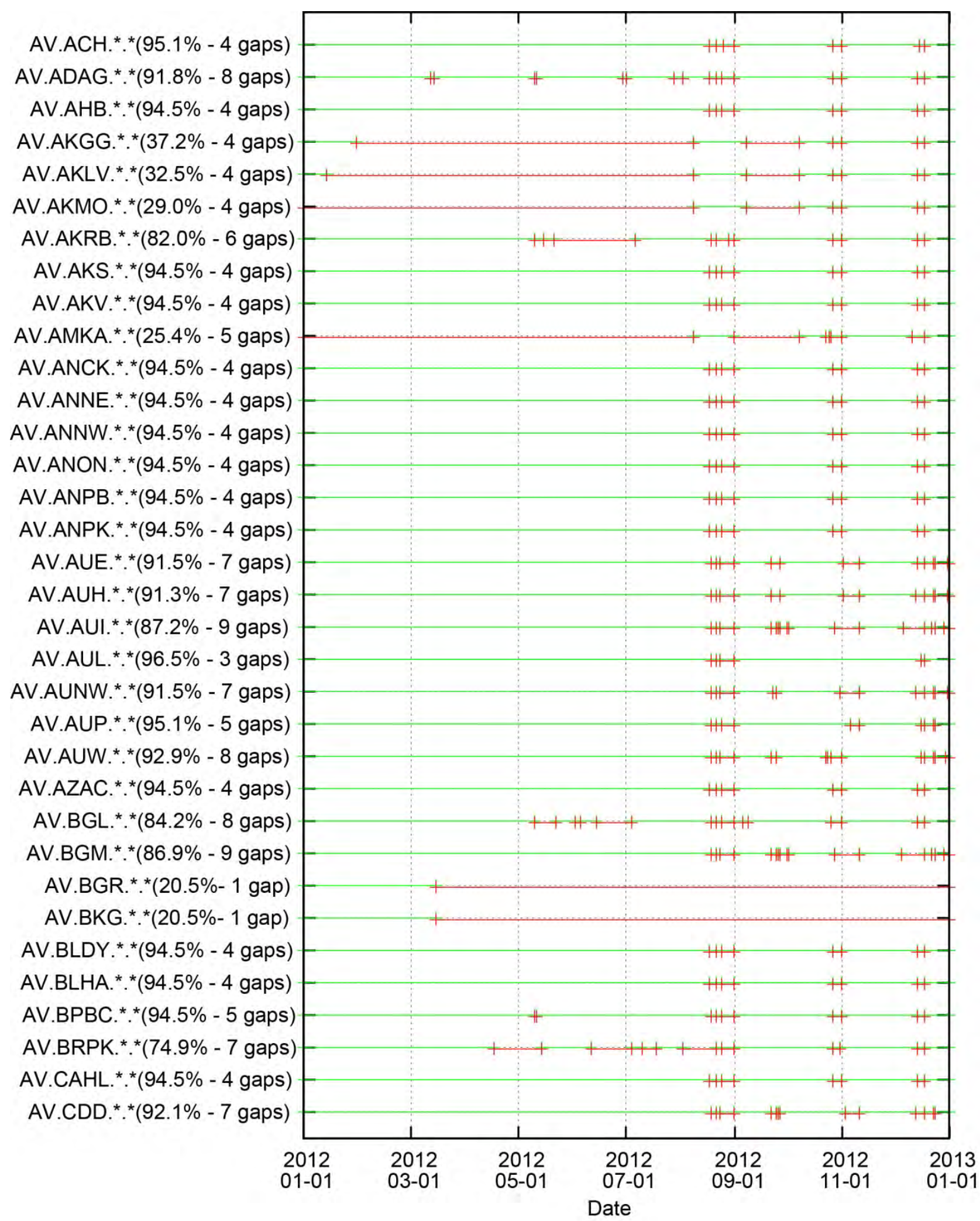




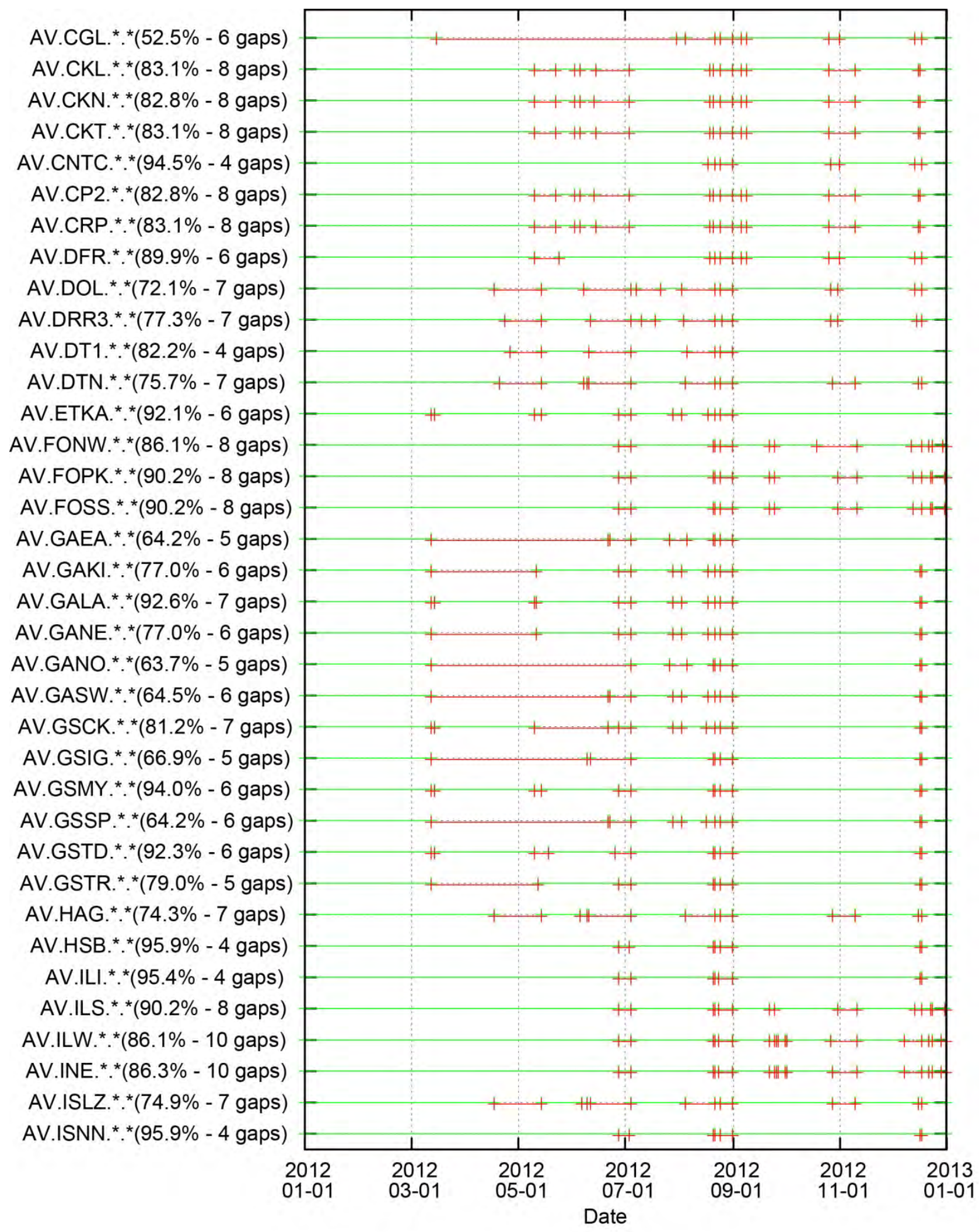




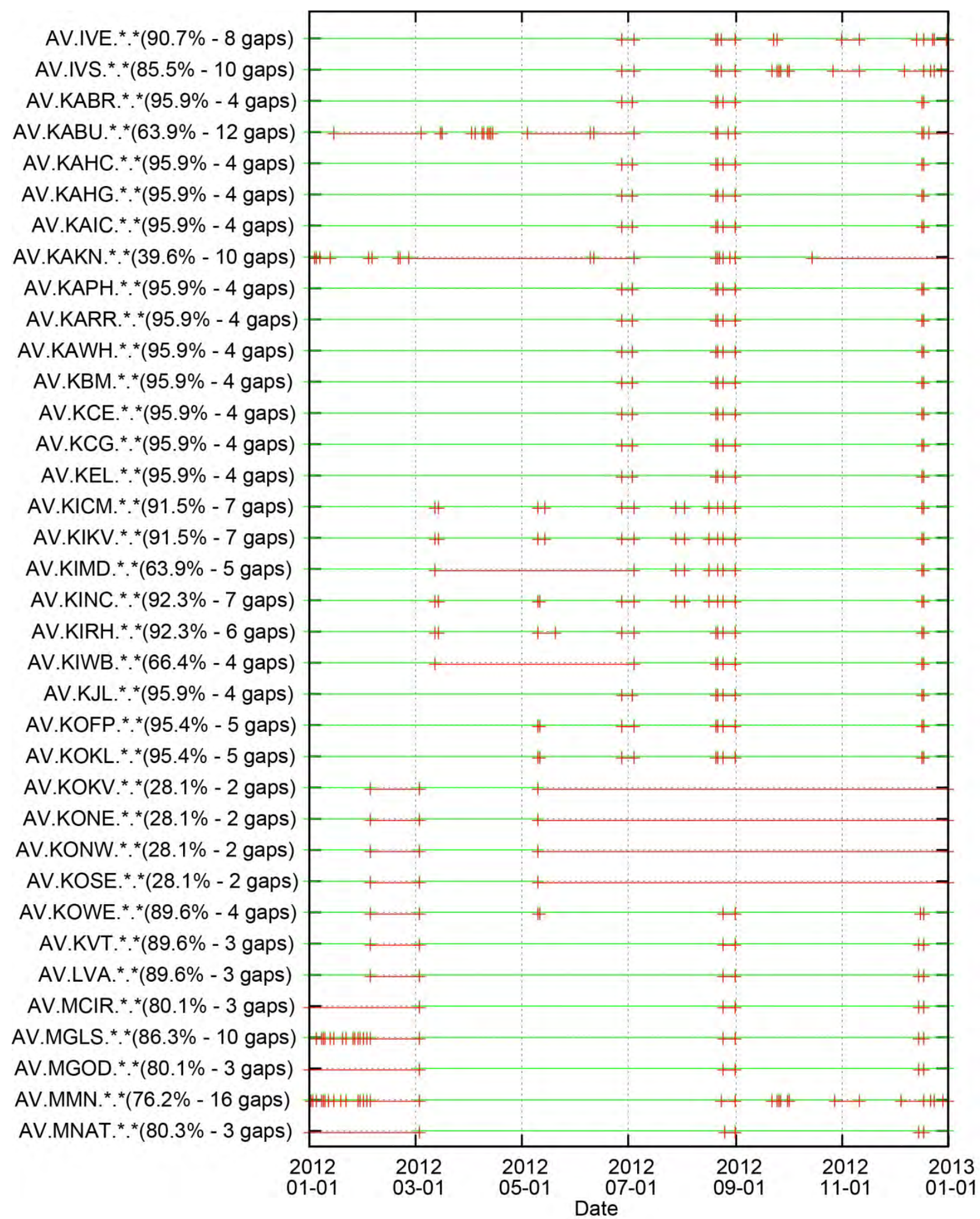


AV.MREP.*.*(75.7\% - 15 gaps) AV.MSOM.*.*(43.2\% - 2 gaps $)$ AV.MSW.***(85.8\% - 8 gaps) AV.MTBL. ${ }^{*}{ }^{*}(80.1 \%-3$ gaps $)$ AV.NCG.**( $6.6 \%-8$ gaps $)$ AV.NCT.***(36.9\% - 12 gaps) AV.OKAK.*.*(73.0\% - 12 gaps) AV.OKCF.***(73.5\% - 14 gaps $)$ AV.OKER. .*. ${ }^{*}(73.5 \%$ - 13 gaps $)$ AV.OKFG. ..*( $1.9 \%$ - 2 gaps) AV.OKID.*.*(72.7\% - 13 gaps) AV.OKSP.** ${ }^{*}(72.7 \%$ - 13 gaps $)$ AV.OKTU.*.*(73.2\% - 14 gaps) AV.OKWE. ***(72.7\% - 12 gaps) AV.OKWR..**(72.7\% - 14 gaps $)$ AV.OPT.*.*(76.5\% - 11 gaps) AV.PDB. .**(71.9\% - 15 gaps $)$ AV.PLBL. **(76.0\% - 11 gaps) AV.PLK1.***(76.0\% - 11 gaps $)$ AV.PLK2. ** ${ }^{*}(76.0 \%$ - 11 gaps $)$ AV.PLK3. ${ }^{*}{ }^{*}(76.5 \%$ - 11 gaps $)$ AV.PLK4. ** ${ }^{*}(76.2 \%$ - 11 gaps $)$ AV.PLK5. ** ${ }^{*}(75.7 \%$ - 11 gaps $)$ AV.PLWL...*(76.0\% - 11 gaps) AV.PN7A.***(83.1\% - 8 gaps) AV.PS1A. * *(65.3\% - 12 gaps) AV.PS4A. ** ${ }^{*}(65.6 \%-12$ gaps $)$ AV.PV6. **(83.3\% - 8 gaps $)$ AV.PVV. .* *(71.6\% - 7 gaps $)$ AV.RDJH. .* ${ }^{*}(84.7 \%-12$ gaps $)$ AV.RDN.***(83.3\% - 4 gaps) AV.RDT.***(86.6\% - 7 gaps $)$ AV.RED..**(93.5\% - 4 gaps $)$ AV.REF.*.*(83.1\% - 4 gaps) AV.RSO.**(86.6\% - 7 gaps)

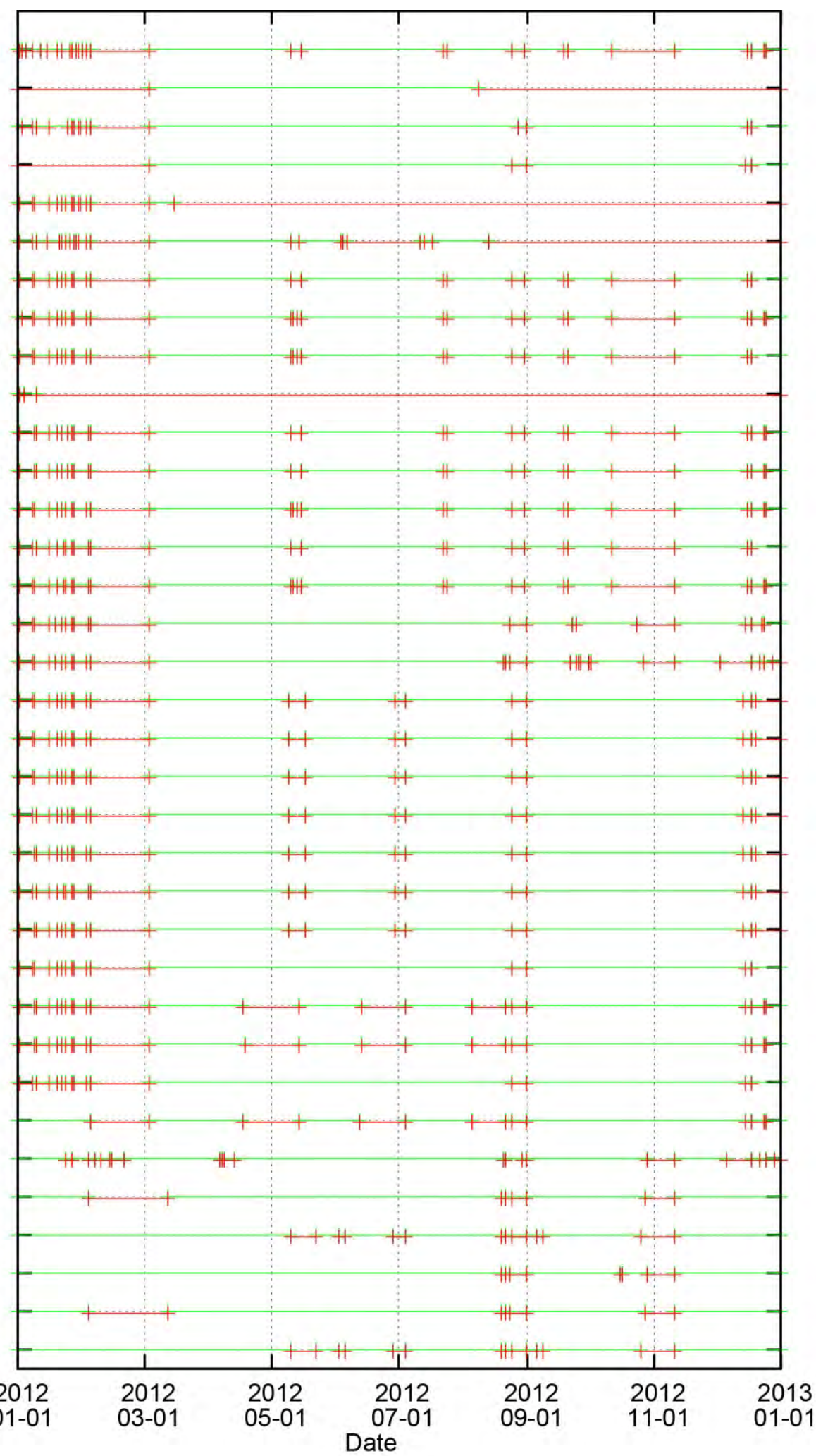




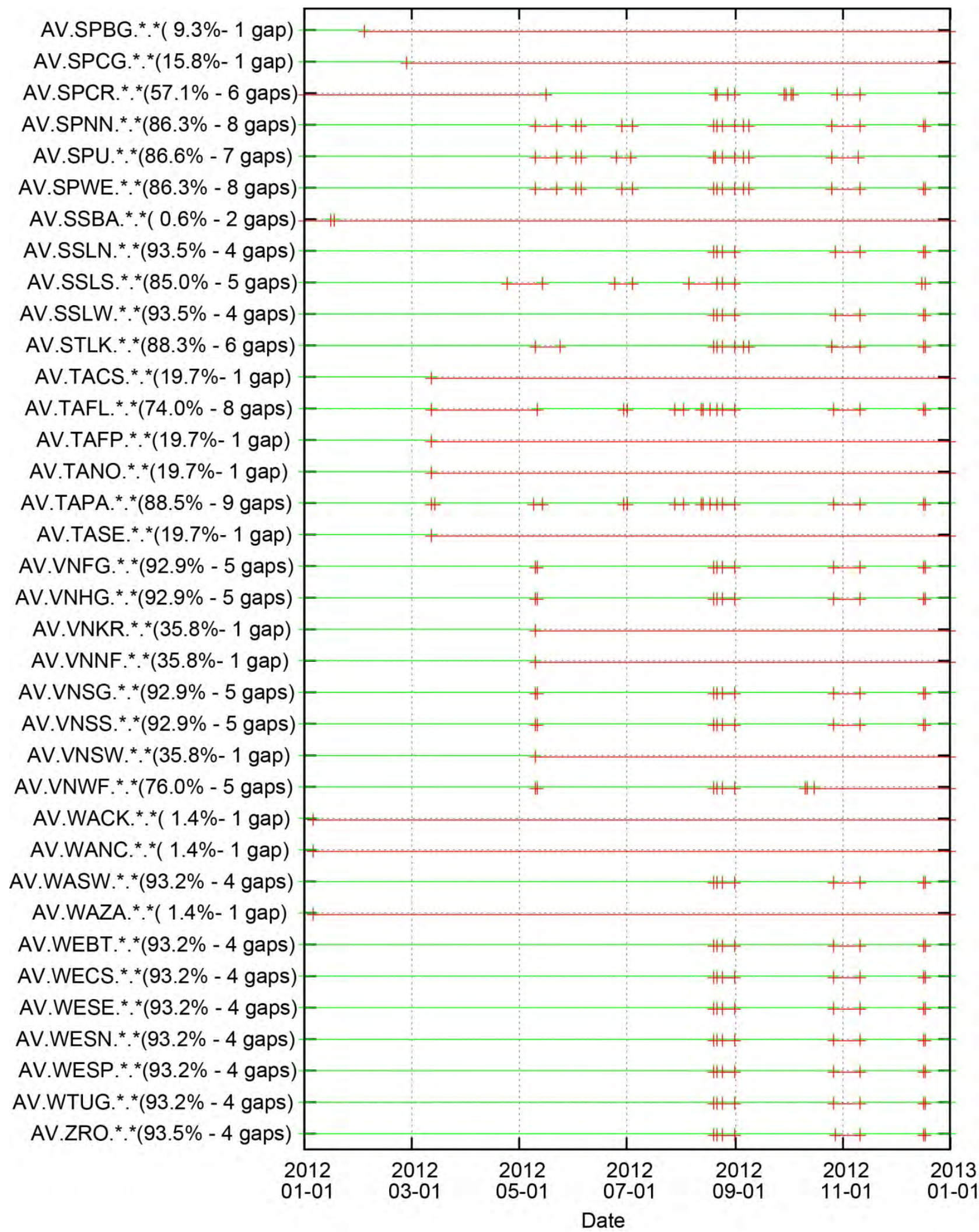




\section{Appendix E. Description of Earthquake List Parameters.}

The attached data file has a listing of all events included in the ANSS catalog with the following parameters:

Date and Time in Coordinated Universal Time (UTC): year, month, day, hour, minute, second.

Hypocenter in latitude (N) and longitude (E) in decimal degrees in the WGS84 datum. Depth is specified in $\mathrm{km}$ below mean sea level.

Magnitude (mag) is the preferred magnitude, ML.

Hypocentral errors are shown as: the weighted root-mean-square travel time residual error:

(RMS), the depth error (ERZ) as defined as the largest projection of the three principal errors on a vertical line, and the horizontal error $(E R H)$ as defined as the length of the largest projection of the three principal errors on a horizontal plane.

Event gap (gap) is the largest azimuthal gap between azimuthally adjacent stations.

Number of phases (n), P and S, used in the hypocentral solution.

Quality (quality) of the solution is a one-letter quality code based on based on errors and goodness-of-fit:

Quality criteria:
A. RMS $<0.15 \mathrm{sec}$ and ERH $<1.0 \mathrm{~km}$ and ERZ $<2.0 \mathrm{~km}$
B. RMS $<0.30 \mathrm{sec}$ and $\mathrm{ERH}<2.5 \mathrm{~km}$ and $\mathrm{ERZ}<5.0 \mathrm{~km}$
C. RMS $<0.50 \mathrm{sec}$ and $\mathrm{ERH}<5.0 \mathrm{~km}$
D. Worse than above

Type of event (type) as described in table E2.

Region of the event (event region) is the full name of the geographical region (table E3).

Software and location program used to locate the event (source). Xpick refers to earthquakes located with the data analysis program XPICK and the earthquake location program HYPOELLIPSE. Jiggle refers to earthquakes located with the data analysis program Jiggle and the earthquake location program HYPOINVERSE.

Database ID (database id) is a unique number assigned to each event origin in the AQMS database. 
Table E1. AVO event type for Xpick and Jiggle. Each event was identified by a description code (table 4) modified after Lahr and others (1994), and stored as a comment in the event location pick file a database parameter.

\begin{tabular}{|l|l|}
\hline Xpick Event Classification (code) & Jiggle Event Classification (code) \\
\hline volcano-tectonic (a) & local earthquake (le) \\
\hline low-frequency (b) & long-period volcanic earthquake (lp) \\
\hline hybrid (h) & long-period volcanic earthquake (lp) \\
\hline shore-ice (i) & snow-ice avalanche (av) \\
\hline cause unknown (x) & unknown type (uk) \\
\hline regional-volcanic (R) & regional earthquake (re) \\
\hline regional-tectonic (E) & regional earthquake (re) \\
\hline teleseismic (T) & teleseismic earthquake (ts) \\
\hline glacier (G) & snow-ice avalanche (av) \\
\hline calibrations (C) & calibration (ce) \\
\hline other non-seismic (O) & debris flow/avalanche (df) \\
\hline other non-seismic (O) & other miscellaneous (ot) \\
\hline
\end{tabular}

Table E2. Event Regions and the corresponding volcanic center in each geographical region.

\begin{tabular}{|l|l|}
\hline \multicolumn{1}{|c|}{ Event Region } & \multicolumn{1}{c|}{ Associated subnetwork } \\
\hline Central Alaska & Wrangell \\
\hline Cook Inlet Region & Augustine, Iliamna, Redoubt, Spurr \\
\hline Kodiak Island Region & Fourpeaked \\
\hline Alaska Peninsula Region & $\begin{array}{l}\text { Aniakchak, Dutton, Katmai, Pavlof, } \\
\text { Peulik, Veniaminof }\end{array}$ \\
\hline Unimak Island Region & Isanotski, Shishaldin, Westdahl \\
\hline Fox Island Region & Akutan, Makushin, Okmok \\
\hline Andreanof Island Region & $\begin{array}{l}\text { Gareloi, Great Sitkin, Kanaga, } \\
\text { Korovin, Tanaga }\end{array}$ \\
\hline Rat Island Region & Cerberus, Little Sitkin \\
\hline
\end{tabular}




\section{Appendix F. Seismic Velocity Models Used in Locating the Earthquakes in 2012.}

Following the name of each velocity model is a list of volcano subnetworks for which the model is used. Depths are referenced to sea level, with negative values reflecting height above sea level.

\begin{tabular}{|c|c|c|c|c|c|}
\hline Velocity Model & $\begin{array}{c}\text { Latitude } \\
\left({ }^{\circ} \mathbf{N}\right)\end{array}$ & $\begin{array}{c}\text { Longitude } \\
\left({ }^{\circ} \mathrm{E}\right)\end{array}$ & $\begin{array}{c}\text { Radius } \\
\text { (km) }\end{array}$ & $\begin{array}{l}\text { Top } \\
\text { (km) }\end{array}$ & $\begin{array}{c}\text { Bottom } \\
(\mathbf{k m})\end{array}$ \\
\hline Spurr & 61.60 & -152.40 & 20 & -3 & 50 \\
\hline Spurr & 61.47 & -152.33 & 20 & -3 & 50 \\
\hline Spurr & 61.33 & -152.25 & 20 & -3 & 50 \\
\hline Spurr & 61.17 & -152.35 & 20 & -3 & 50 \\
\hline Spurr & 61.00 & -152.45 & 20 & -3 & 50 \\
\hline Redoubt & 60.83 & -152.55 & 20 & -3 & 50 \\
\hline Redoubt & 60.66 & -152.66 & 20 & -3 & 50 \\
\hline Redoubt & 60.49 & -152.75 & 20 & -3 & 50 \\
\hline Redoubt & 60.34 & -152.86 & 20 & -3 & 50 \\
\hline Iliamna & 60.03 & -153.09 & 20 & -3 & 50 \\
\hline Augustine & 59.36 & -153.42 & 20 & -3 & 50 \\
\hline Katmai & 58.17 & -155.35 & 20 & -3 & 50 \\
\hline Katmai & 58.29 & -154.86 & 20 & -3 & 50 \\
\hline Katmai & 58.35 & -155.09 & 20 & -3 & 50 \\
\hline Katmai & 58.43 & -154.38 & 20 & -3 & 50 \\
\hline Veniaminof & 56.18 & -159.38 & 30 & -3 & 50 \\
\hline Cold Bay & 55.42 & -161.89 & 20 & -3 & 50 \\
\hline Cold Bay & 55.18 & -162.27 & 20 & -3 & 50 \\
\hline Cold Bay & 54.76 & -163.97 & 30 & -3 & 50 \\
\hline Westdahl & 54.52 & -164.65 & 20 & -3 & 50 \\
\hline Akutan & 54.15 & -165.97 & 20 & -3 & 50 \\
\hline Makushin & 53.89 & -166.92 & 20 & -3 & 50 \\
\hline Okmok & 53.40 & -168.16 & 20 & -3 & 50 \\
\hline Andreanof & 52.08 & -176.13 & 20 & -3 & 50 \\
\hline Andreanof & 51.93 & -176.75 & 20 & -3 & 50 \\
\hline Andreanof & 51.92 & -177.17 & 20 & -3 & 50 \\
\hline Tanaga & 51.89 & -178.15 & 20 & -3 & 50 \\
\hline
\end{tabular}


74 Catalog of Earthquake Hypocenters at Alaskan Volcanoes: January 1 through December 31, 2012

Akutan Velocity Model (Power and others, 1996).

$\begin{array}{cccc}\text { Layer number } & \mathbf{V p}(\mathbf{k m} / \mathbf{s e c}) & \text { Top of layer }(\mathbf{k m}) & \mathbf{V p} / \mathbf{V s} \\ 1 & 2.30+0.37 \mathrm{~km} / \mathrm{sec} \text { for each km of depth } & -3.0 & 1.80 \\ 2 & 6.30 & 7.0 & 1.80\end{array}$

Andreanof Velocity Model (Toth and Kisslinger, 1984).

$\begin{array}{cccc}\text { Layer number } & \text { Vp (km/sec) } & \text { Top of layer }(\mathbf{k m}) & \mathbf{V p} / \mathbf{V s} \\ 1 & 3.50 & -3.0 & 1.73 \\ 2 & 3.88 & -2.8 & 1.73 \\ 3 & 4.25 & -2.6 & 1.73 \\ 4 & 4.62 & -2.4 & 1.73 \\ 5 & 5.00 & -2.2 & 1.73 \\ 6 & 5.50 & -2.0 & 1.73 \\ 7 & 5.62 & -1.0 & 1.73 \\ 8 & 5.74 & 0.0 & 1.73 \\ 9 & 5.86 & 1.0 & 1.73 \\ 10 & 5.98 & 2.0 & 1.73 \\ 11 & 6.10 & 3.0 & 1.73 \\ 12 & 6.60 & 4.0 & 1.73 \\ 13 & 6.68 & 5.0 & 1.73 \\ 14 & 6.80 & 8.0 & 1.73 \\ 15 & 6.92 & 11.0 & 1.73 \\ 16 & 7.04 & 14.0 & 1.73 \\ 17 & 7.16 & 17.0 & 1.73 \\ 18 & 7.28 & 20.0 & 1.73 \\ 19 & 7.85 & 23.0 & 1.73 \\ 20 & 8.05 & 37.0 & 1.73\end{array}$

Augustine Velocity Model (Power, 1988).

$\begin{array}{cccc}\text { Layer number } & \mathbf{V p}(\mathbf{k m} / \mathbf{s e c}) & \text { Top of layer } \mathbf{( k m )} & \mathbf{V p} / \mathbf{V s} \\ 1 & 2.3 & -3.0 & 1.80 \\ 2 & 2.6 & -0.7 & 1.80 \\ 3 & 3.4 & 0.0 & 1.80 \\ 4 & 5.1 & 1.0 & 1.80 \\ 5 & 6.3 & 9.0 & 1.78 \\ 6 & 8.0 & 44.0 & 1.78\end{array}$


Cold Bay Velocity Model (McNutt and Jacob, 1986).

$\begin{array}{cccc}\text { Layer number } & \mathbf{V p}(\mathbf{k m} / \mathbf{s e c}) & \text { Top of layer } \mathbf{( k m )} & \mathbf{V p} / \mathbf{V s} \\ 1 & 3.05 & -3.00 & 1.78 \\ 2 & 3.44 & 0.00 & 1.78 \\ 3 & 5.56 & 1.79 & 1.78 \\ 4 & 6.06 & 3.65 & 1.78 \\ 5 & 6.72 & 10.18 & 1.78 \\ 6 & 7.61 & 22.63 & 1.78 \\ 7 & 7.90 & 38.51 & 1.78\end{array}$

Iliamna Velocity Model (Roman and others, 2001).

Layer number

1
2
3
4
5
6

Vp (km/sec)

4.8

6.1

6.2

6.3

6.4

7.1
Top of layer $(\mathbf{k m})$

$-3.0$

$-1.6$

1.7

2.9

3.1

16.5
$\mathbf{V p} / \mathbf{V s}$

1.78

1.78

1.78

1.78

1.78

1.78

Katmai Velocity Model (Searcy, 2003).

$\begin{array}{cccc}\text { Layer number } & \mathbf{V p}(\mathbf{k m} / \mathbf{s e c}) & \text { Top of layer } \mathbf{( k m )} & \mathbf{V p} / \mathbf{V s} \\ 1 & 5.05 & -3.0 & 1.78 \\ 2 & 5.10 & 1.0 & 1.78 \\ 3 & 5.41 & 2.0 & 1.78 \\ 4 & 5.49 & 3.0 & 1.78 \\ 5 & 5.65 & 4.0 & 1.78 \\ 6 & 5.67 & 5.0 & 1.78 \\ 7 & 5.69 & 6.0 & 1.78 \\ 8 & 5.76 & 7.0 & 1.78 \\ 9 & 5.80 & 8.0 & 1.78 \\ 10 & 6.00 & 9.0 & 1.78 \\ 11 & 6.04 & 10.0 & 1.78 \\ 12 & 6.08 & 12.0 & 1.78 \\ 13 & 6.30 & 15.0 & 1.78 \\ 14 & 6.73 & 20.0 & 1.78 \\ 15 & 7.54 & 25.0 & 1.78 \\ 16 & 7.78 & 33.0 & 1.78\end{array}$


Makushin Velocity Model (Cheryl Searcy, written commun., 2010).

$\begin{array}{cccc}\text { Layer number } & \mathbf{V p}(\mathbf{k m} / \mathbf{s e c}) & \text { Top of layer } \mathbf{( k m )} & \mathbf{V p} / \mathbf{V s} \\ 1 & 3.88 & -3.0 & 1.86 \\ 2 & 3.92 & 0.0 & 1.88 \\ 3 & 3.99 & 1.0 & 1.61 \\ 4 & 4.11 & 2.0 & 1.66 \\ 5 & 4.81 & 3.0 & 1.70 \\ 6 & 5.40 & 4.0 & 1.91 \\ 7 & 5.82 & 4.5 & 1.77 \\ 8 & 6.40 & 5.0 & 1.70 \\ 9 & 6.53 & 9.0 & 1.68 \\ 10 & 6.92 & 10.0 & 1.71 \\ 11 & 7.37 & 11.0 & 1.82 \\ 12 & 7.68 & 23.0 & 1,78 \\ 13 & 8.08 & 28.0 & 1.78\end{array}$

Okmok Velocity Model (Masterlark and others, 2010).

$\begin{array}{cccc}\text { Layer number } & \mathbf{V p}(\mathbf{k m} / \mathbf{s e c}) & \text { Top of layer }(\mathbf{k m}) & \mathbf{V p} / \mathbf{V s} \\ 1 & 3.830 & -3.0 & 1.73 \\ 2 & 3.891 & 0.0 & 1.73 \\ 3 & 5.084 & 1.0 & 1.73 \\ 4 & 5.187 & 2.0 & 1.73 \\ 5 & 5.470 & 3.0 & 1.73 \\ 6 & 6.185 & 4.0 & 1.73 \\ 7 & 6.191 & 10.0 & 1.73 \\ 8 & 6.454 & 12.0 & 1.73 \\ 9 & 6.896 & 16.0 & 1.73 \\ 10 & 7.414 & 20.0 & 1.73\end{array}$

Redoubt Velocity Model (Lahr and others, 1994).

$\begin{array}{cccc}\text { Layer number } & \mathbf{V p}(\mathbf{k m} / \mathbf{s e c}) & \text { Top of layer } \mathbf{( k m )} & \mathbf{V p} / \mathbf{V s} \\ 1 & 2.90 & -3.0 & 1.80 \\ 2 & 5.10 & -1.7 & 1.80 \\ 3 & 6.40 & 1.5 & 1.72 \\ 4 & 7.00 & 17.0 & 1.78\end{array}$


Spurr Velocity Model (Jolly and others, 1994).

Layer number

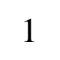

2

3

4
Vp ( km/sec)

\section{1}

5.5

6.3

7.2
Top of layer $(\mathbf{k m})$

$$
-3.00
$$$$
-2.00
$$

5.25

27.25
$\mathbf{V p} / \mathbf{V s}$

1.81

1.81

1.74

1.78

Tanaga Velocity Model (Power, written commun., 2005).

\section{Layer number}

1
2
3
4
5
6
7
8

\section{Vp (km/sec)}

4.0

4.5

5.0

5.6

6.9

7.2

7.8

8.1
Top of layer $(\mathbf{k m})$

$-3.0$

$-1.2$

0.0

4.0

10.0

15.0

20.0

33.0
$\mathbf{V p} / \mathbf{V s}$

1.78

1.78

1.78

1.78

1.78

1.78

1.78

1.78

Veniaminof Velocity Model (Sánchez, 2005).

$\begin{array}{cccc}\text { Layer number } & \mathbf{V p}(\mathbf{k m} / \mathbf{s e c}) & \text { Top of layer } \mathbf{( k m )} & \mathbf{V p} / \mathbf{V s} \\ 1 & 4.82 & -3.0 & 1.73 \\ 2 & 5.23 & 4.0 & 1.88 \\ 3 & 5.23 & 10.0 & 1.38 \\ 4 & 6.49 & 15.0 & 1.65 \\ 5 & 6.52 & 20.0 & 1.51 \\ 6 & 8.18 & 25.0 & 1.89 \\ 7 & 8.21 & 33.0 & 1.90 \\ 8 & 8.21 & 47.0 & 1.80 \\ 9 & 8.30 & 65.0 & 1.78\end{array}$

Westdahl Velocity Model (Dixon and others, 2005).

Layer
1
2
3
4
5
6
7
8

\section{Vp (km/sec)}

3.03

3.18

5.03

5.70

6.30

6.82

7.17

8.16
Top of layer $(\mathbf{k m})$

$-3.0$

0.0

2.0

8.0

10.0

16.0

26.0

38.0
Vp/Vs

1.71

1.71

1.71

1.71

1.71

1.71

1.71

1.71 
78 Catalog of Earthquake Hypocenters at Alaskan Volcanoes: January 1 through December 31, 2012

Regional Velocity Model (Fogleman and others, 1993).

$\begin{array}{cccc}\text { Layer number } & \mathbf{V p}(\mathbf{k m} / \mathbf{s e c}) & \text { Top of layer } \mathbf{( k m )} & \mathbf{V p} / \mathbf{V s} \\ 1 & 5.3 & -3.0 & 1.78 \\ 2 & 5.6 & 4.0 & 1.78 \\ 3 & 6.2 & 10.0 & 1.78 \\ 4 & 6.9 & 15.0 & 1.78 \\ 5 & 7.4 & 20.0 & 1.78 \\ 6 & 7.7 & 25.0 & 1.78 \\ 7 & 7.9 & 33.0 & 1.78 \\ 8 & 8.1 & 47.0 & 1.78 \\ 9 & 8.3 & 65.0 & 1.78\end{array}$




\section{Appendix G. Location of Volcanic Zones Modeled Using Multiple Cylinders.}

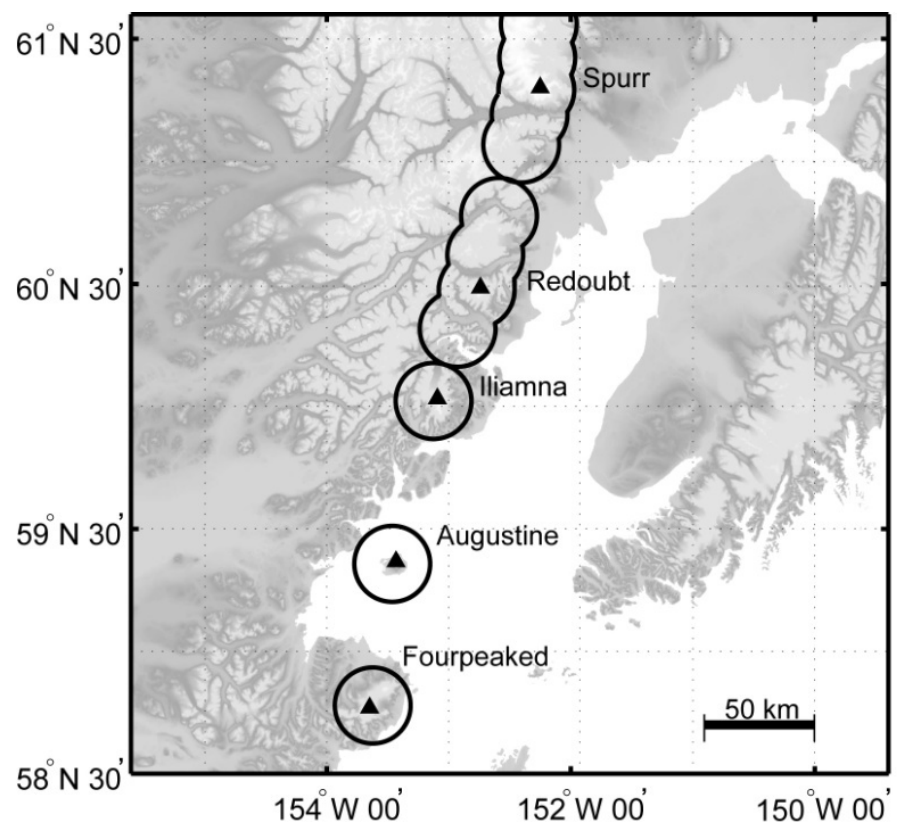

Figure G1. Volcanic zones for the Cook Inlet Volcanoes. Five overlapping cylinders model the Spurr volcanic zone. Four overlapping cylinders model the Redoubt volcanic zone. Single cylinders model the lliamna, Augustine, and Fourpeaked volcanic zones.

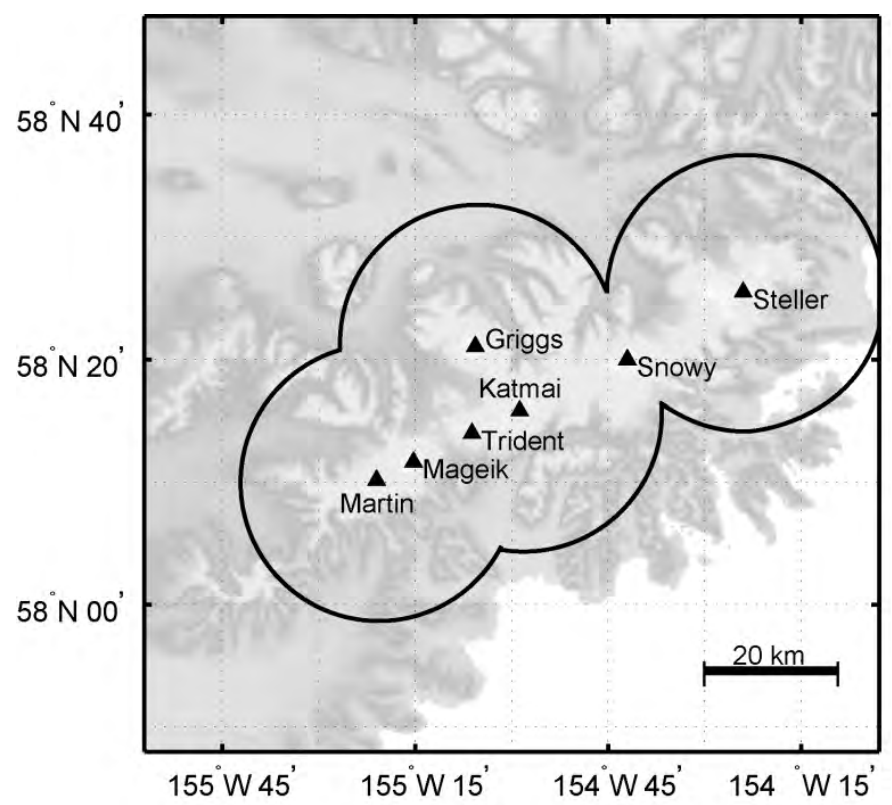

Figure G2. Volcanic zone for the Katmai volcanic cluster. The volcanic zone is modeled using four overlapping cylinders centered on Mount Martin, Mount Katmai, Mount Griggs, and Mount Steller. 


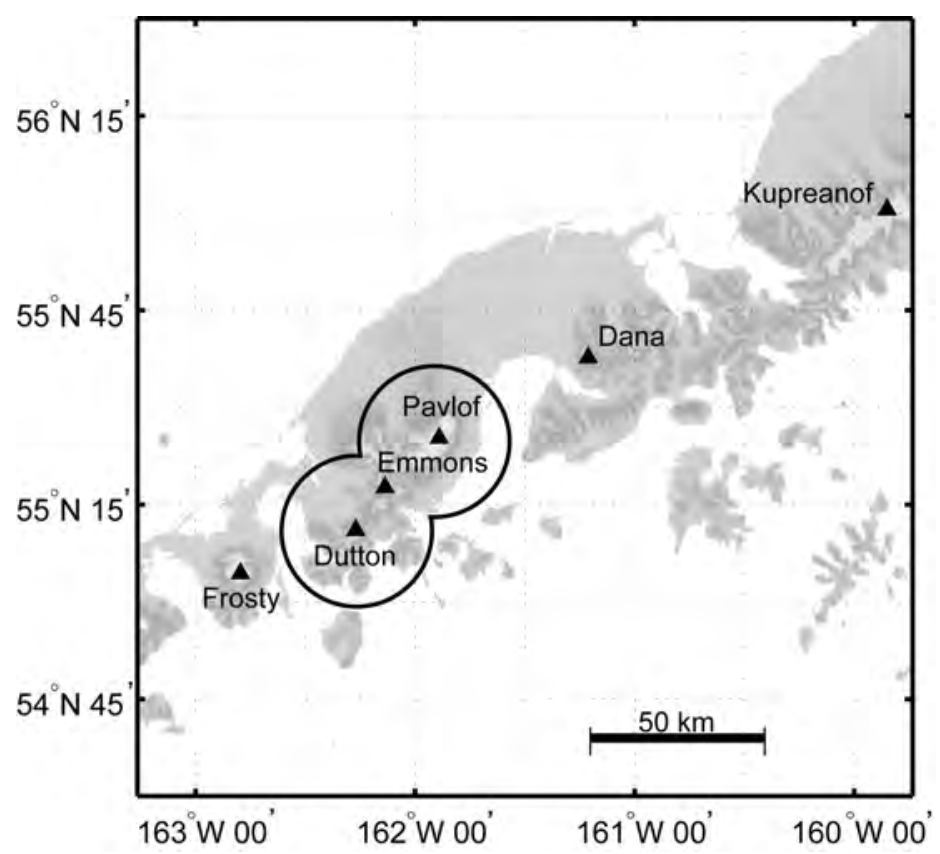

Figure G3. Volcanic zones for Pavlof Volcano and Mount Dutton. The volcanic zone is modeled using two overlapping cylinders centered on Mount Dutton and Pavlof Volcano.

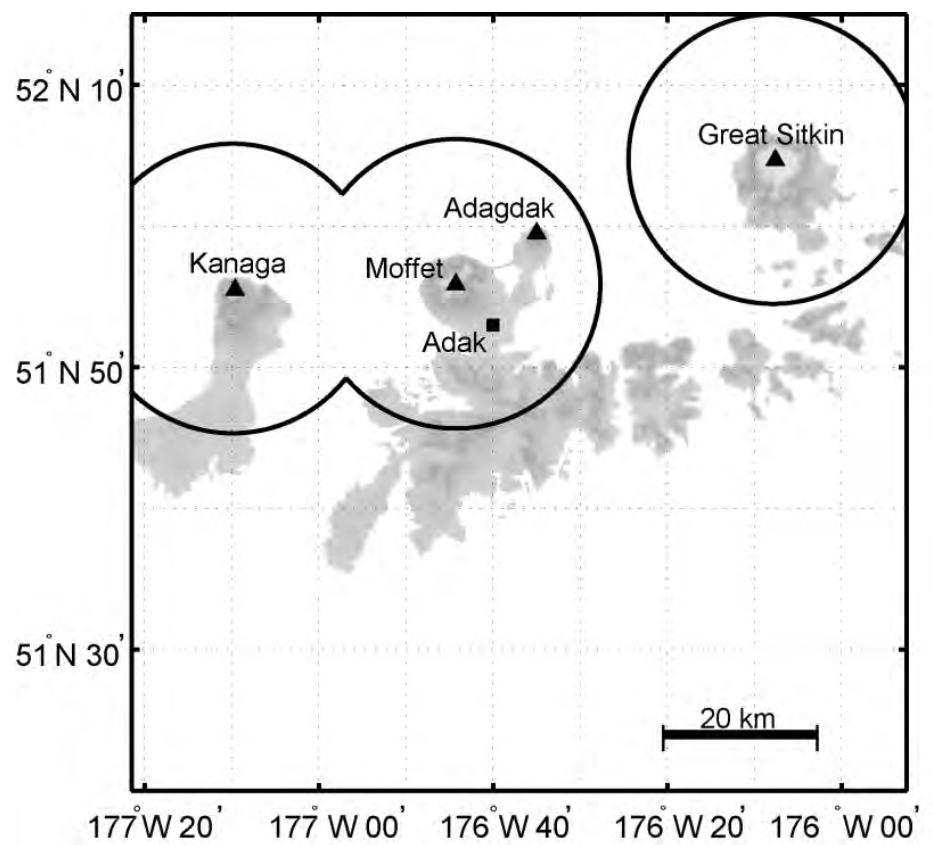

Figure G4. Volcanic zones in the Adak region. The volcanic zones are modeled using cylinders centered on Kanaga Volcano, Mount Moffett, and Great Sitkin Volcano. 


\section{Appendix H. Previous AVO Earthquake Catalogs.}

Earthquake catalog for 1989-present available from the USGS.

1989-90: Power, J.A., March, G.D., Lahr, J.C., Jolly, A.D., and Cruse, G.R., 1993, Catalog of earthquake hypocenters at Redoubt Volcano and Mount Spurr, Alaska: October 12, 1989 - December 31, 1990: U.S. Geological Survey Open-File Report 93-685-A, 57 p.

1991-93: Jolly, A.D., Power, J.A., Stihler, S.D., Rao, L.N., Davidson, G., Paskievitch, J., Estes, S., and Lahr, J.C., 1996, Catalog of earthquake hypocenters for Augustine, Redoubt, Iliamna, and Mount Spurr Volcanoes, Alaska: January 1, 1991 - December 31, 1993: U.S. Geological Survey Open-File Report 96-70, 90 p.

1994-99: Jolly, A.D., Stihler, S.D., Power, J.A., Lahr, J.C., Paskievitch, J., Tytgat, G., Estes, S., Lockhart, A.B., Moran, S.C., McNutt, S.R., and Hammond, W.R., 2001, Catalog of earthquake hypocenters at Alaskan Volcanoes: January 1, 1994 - December 31, 1999: U.S. Geological Survey Open-File Report 01-189, $202 \mathrm{p}$.

URL: http://geopubs.wr.usgs.gov/open-file/of01-189/(last accessed April 1, 2012)

2000-01: Dixon, J.P, Stihler, S.D., Power, J.A., Tytgat, G., Estes, S., Moran, S.C., Paskievitch, J., and McNutt, S.R., 2002, Catalog of Earthquake Hypocenters at Alaska Volcanoes: January 1, 2000 - December 31, 2001: U.S. Geological Survey Open-File Report 02-342, 56 p.

URL: http://geopubs.wr.usgs.gov/open-file/of02-342/(last accessed April 1, 2012)

2002: Dixon, J.P., Stihler, S.D., Power, J.A., Tytgat, G., Moran, S.C., Sánchez, J.J., Estes, S., McNutt, S.R., and Paskievitch, J., 2003, Catalog of Earthquake Hypocenters at Alaska Volcanoes: January 1 December 31, 2002: U.S. Geological Survey Open-File Report 03-267, 58 p.

URL: http://geopubs.wr.usgs.gov/open-file/of03-267/(last accessed April 1, 2012)

2003: Dixon, J.P., Stihler, S.D., Power, J.A., Tytgat, G., Moran, S.C., Sánchez, J.J., Estes, S., McNutt, S.R., and Paskievitch, J., 2004, Catalog of Earthquake Hypocenters at Alaska Volcanoes: January 1 December 31, 2003: U.S. Geological Survey Open-File Report 2004-1234, 59 p.

URL: http://pubs.usgs.gov/of/2004/1234/(last accessed April 1, 2012)

2004: Dixon, J.P., Stihler, S.D., Power, J.A., Tytgat, G., Estes, S., Prejean, S., Sánchez, J.J., Sanches, R., McNutt, S.R., and Paskievitch, J., 2005, Catalog of Earthquake Hypocenters at Alaskan Volcanoes: January 1 through December 31, 2004: U.S. Geological Survey Open-File Report 2005-1312, 74 p.

URL: http://pubs.usgs.gov/of/2005/1312/(last accessed April 1, 2012)

2005: Dixon, J.P., Stihler, S.D., Power, J.A., Tytgat, G., Estes, S., and McNutt, S.R., 2007, Catalog of Earthquake Hypocenters at Alaskan Volcanoes: January 1 through December 31, 2005: U.S. Geological Survey Open-File Report 2007-1264, 78 p.

URL: http://pubs.usgs.gov/of/2006/1264/ (last accessed April 1, 2012)

2006: Dixon, J.P., Stihler, S.D., Power, J.A., and Searcy, Cheryl, 2008, Catalog of earthquake hypocenters at Alaskan Volcanoes: January 1 through December 31, 2006: U.S. Geological Survey Data Series 326, $78 \mathrm{p}$.

URL: http://pubs.usgs.gov/ds/326/pdf/ds326.pdf (last accessed April 1, 2012) 
2007: Dixon, J.P., Stihler, S.D., and Power, J.A., and Searcy, Cheryl, 2008, Catalog of earthquake hypocenters at Alaskan Volcanoes: January 1 through December 31, 2007: U.S. Geological Survey Data Series 367, $82 \mathrm{p}$.

URL: http://pubs.usgs.gov/ds/367/pdf/ds367.pdf(last accessed April 1, 2012)

2008: Dixon, J.P., and Stihler, S.D, 2009, Catalog of earthquake hypocenters at Alaskan Volcanoes: January 1 through December 31, 2008: U.S. Geological Survey Data Series 467, 88 p. URL: http://pubs.usgs.gov/ds/467/pdf/ds467.pdf(last accessed April 1, 2012)

2009: Dixon, J.P., and Stihler, S.D, Power, J.A., and Searcy, Cheryl, 2010, Catalog of earthquake hypocenters at Alaskan Volcanoes: January 1 through December 31, 2009: U.S. Geological Survey Data Series 531, $84 \mathrm{p}$.

URL: http://pubs.usgs.gov/ds/531/pdf/ds531.pdf(last accessed April 1, 2012)

2010: Dixon, J.P., and Stihler, S.D, Power, J.A., and Searcy, Cheryl, 2011, Catalog of earthquake hypocenters at Alaskan Volcanoes: January 1 through December 31, 2010: U.S. Geological Survey Data Series 645, $82 \mathrm{p}$.

URL: http://pubs.usgs.gov/ds/645/(last accessed April 1, 2012)

2011: Dixon, J.P., and Stihler, S.D, Power, J.A., and Searcy, Cheryl, 2012, Catalog of earthquake hypocenters at Alaskan Volcanoes: January 1 through December 31, 2011: U.S. Geological Survey Data Series 730, $90 \mathrm{p}$.

URL: http://pubs.usgs.gov/ds/730/ (last accessed April 1, 2012) 


\section{Appendix I. Selected Papers Published Using Data Provided by AVO.}

Brown, J. R., S. G. Prejean, G. C. Beroza, J. Gomberg, and P. J. Haeussler (2012), Deep Low-Frequency Earthquakes in Tectonic Tremor Along the Alaska-Aleutian Subduction Zone, J. Geophys. Res., doi:10.1029/2012JB009459, in press.

Buurman, H., West, M.E., and Thompson, G., 2012, The seismicity of the 2009 Redoubt eruption, JVGR, doi:10.1016/j.jvolgeores.2012.04.024

Buurman, H., West, M.E. and Roman, D.C., 2013, Using repeating volcano-tectonic earthquakes to track post-eruptive activity in the conduit system at Redoubt Volcano, Alaska, Geology, doi:10.1130/G34089.1

Dawson, P.B., Chouet, B.A., and Power, John, 2011, Determining the seismic source mechanism and location for an explosive eruption with limited observational data: Augustine Volcano, Alaska: Geophysical Research Letters, v. 38, L03302, doi:10.1029/2010GL045977, 5 p.

De Angelis, S., McNutt, S.R., and Webley, P.W., 2011, Evidence of atmospheric gravity waves during the 2008 eruption of Okmok volcano from seismic and remote sensing observations: Geophysical Research Letters, v. 38, L10303, doi:10.1029/2011GL047144, 6 p.

De Angelis, Silvio, Fee, David, Haney, Matthew, and Schneider, David, 2012, Detecting hidden volcanic explosions from Mt. Cleveland volcano, Alaska, with infrasound and ground-coupled airwaves: Geophysical Research Letters, v. 39, L21312, 6 p., doi: 10.1029/2012GL053635 .

DeRoin, Nicole, and McNutt, S.R., 2012, Rockfalls at Augustine Volcano, Alaska: the influence of eruption precursors and seasonal factors on occurrence patterns 1997-2009: Journal of Volcanology and Geothermal Research, v. 211-212, p. 61-75, doi:10.1016/j.volgeores.2011.11.003.

Haney, M.M., Mikesell, T.D., van Wijk, Kasper, and Nakahara, Hisashi, 2012, Extension of the spatial autocorrelation (SPAC) method to mixed-component correlations of surface waves: Geophysical Journal International, v. 191, p. 189-206, doi:10.1111/j.1365-246X.2012.05597.x .

Haney, M. M., Power, J., West, M., and Michaels, P., 2012, Causal instrument corrections for short-period and broadband seismometers: Seismological Research Letters, v. 83, no. 5, 834-845, doi:

$10.1785 / 0220120031$.

Haney, M. M., Chouet, B. A., Dawson, P. B., and Power, J. A., 2013, Source characterization for an explosion during the 2009 eruption of Redoubt Volcano from very-long-period seismic waves: Journal of Volcanology and Geothermal Research, in press.

Hotovec, Prejean, Gomberg, and Vidale, Redoubt special issue paper on gliding harmonic tremor

Ketner, D.M., Power, J.A., 201?, Characterization of seismic events during the 2009 eruption of Redoubt Volcano, Alaska. JVGR. 
Moretti, L., Mangeney, A., Capdeville, Y., Stutzman, E., Huggel, C., Schneider, D., and Bouchut, F., 2012, Numerical modeling of the Mount Steller landslide flow history and of the generated long period seismic waves: Geophysical Research Letters, v. 39, n. 16, 10 p., doi:10.1029/2012GL052511 .

O'Brien, J.F., Roman, D.C., Dixon, J.P., Power, J.A., and Arnold, Richard, 2012, Multiple causes for noneruptive seismic swarms at Mt. Martin, Katmai Volcanic Cluster, Alaska: Journal of Volcanology and Geothermal Research, v. 229-230, p. 13-22, doi: 10.1016/j.volgeores.2012.03.011.

Peterson, C.L., McNutt, S.R., and Christensen, D.H., Nonvolcanic tremor in the Aleutian Arc: Bulletin of the Seismological Society of America, v. 101, n. 6, p. 3081-3087, doi:10.1785/?0120100241 .

Power, J.A, Stihler, S.D., Chouet, B.A., Haney, M.M., Ketner, D.M., 201?, Seismic observations of Redoubt Volcano, Alaska -- 1989 - 2010 and a conceptual model of the Redoubt Magmatic System. JVGR.

Prejean, S.G, and Brodsky, E.E., 2011, Volcanic plume height measured by seismic waves based on a mechanical model: Journal of Geophysical Research, v. 116, n. B1, B0106, 13 p., doi:

10.1029/2010JB007620.

Prejean, Stephanie, Moran, Seth, and Power, John, 2012, Volcanic earthquakes in Alaska's National Parks: in Winfree, Robert (project lead), Katmai Science Studies: Alaska Park Science Journal, v. 11, n. 1, p. 4045, available online at http://www.nps.gov/akso/nature/science/ak_park_science/volume_11_issue_1.cfm.

Reyes, C.G., and West, M.E., 2011, The waveform suite: a robust platform for manipulating waveforms in MATLAB: Seismological Research Letters, v. 82, n. 1, p. 104-110, doi:10.1785/gssrl.82.1.104.

Ruppert, N.A., Kozyreva, N.P., and Hansen, R.A., 2012, Review of crustal seismicity in the Aleutian Arc and implications for arc deformation: Tectonophysics, v. 522-523, p. 150-157, doi:10.1016/j.tecto.2011.11.024 .

Schaefer, J.R., ed., 2012, The 2009 eruption of Redoubt Volcano, Alaska, with contributions by Bull, Katharine, Cameron, Cheryl, Coombs, Michelle, Diefenbach, Angie, Lopez, Taryn, McNutt, Steve, Neal, Christina, Payne, Allison, Power, John, Schneider, Dave, Scott, William, Snedigar, Seth, Thompson, Glenn, Wallace, Kristi, Waythomas, Chris, Webley, Peter, and Werner, Cynthia: Alaska Division of Geological \& Geophysical Surveys Report of Investigation 2011-5, 45 p., available at http://www.dggs.alaska.gov/pubs/id/23123.

Syracuse, E.M., Thurber, C.H., and Power, J.A., 2011, The Augustine magmatic system as revealed by seismic tomography and relocated earthquake hypocenters from 1994 through 2009: Journal of Geophysical Research, v. 116, B09306, doi: 10.1029/2010JB008129 , 11 p.

Thurber, Clifford, Murphy, Rachel, Prejean, Stephanie, Haney, Matthew, Bennington, Ninfa, Powell, Lee, and Paskievitch, John, 2012: Earthquake studies reveal the magmatic plumbing system of the Katmai volcanoes: in Winfree, Robert (project lead), Katmai Science Studies: Alaska Park Science Journal, v. 11, n. 1, p. 34-39, available online at http://www.nps.gov/akso/nature/science/ak park_science/volume 11 issue 1.cfm. 
Publishing support provided by the U.S. Geological Survey Publishing Network, Tacoma Publishing Service Center

For more information concerning the research in this report, contact the Director, Alaska Volcano Observatory U.S. Geological Survey

4210 University Dr.

Anchorage, Alaska 99508-4650

http://www.avo.alaska.edu/ 
